CENTRO DE DESENVOLVIMENTO SUSTENTÁVEL DO SEMIÁRIDO UNIDADE ACADÊMICA DE CIÊNCIAS SOCIAIS

MESTRADO PROFISSIONAL DE SOCIOLOGIA EM REDE NACIONAL

KÁTIA MARIA DE OLIVEIRA SANTOS

INTERFACE DIGITAL:

A SOCIOLOGIA DAS TECNOLOGIAS DIGITAIS DE INFORMAÇÃO E COMUNICAÇÃO NA ESCOLA 


\title{
INTERFACE DIGITAL: \\ A SOCIOLOGIA DAS TECNOLOGIAS DIGITAIS DE INFORMAÇÃO E COMUNICAÇÃO NA ESCOLA
}

\begin{abstract}
Dissertação apresentada ao Curso de Mestrado em Sociologia em Rede Nacional - PROFSOCIO - ministrado no Centro de Desenvolvimento Sustentável do Semiárido da Universidade Federal de Campina Grande, como requisito parcial para obtenção do título de Mestra em Sociologia.
\end{abstract}

Área de Concentração: Ensino de Sociologia.

Orientador: Professor Dr. Bruno Medeiros Roldão de Araújo.

SUMÉ - PB 
S237i Santos, Kátia Maria de Oliveira.

Interface digital: a sociologia das tecnologias digitais de informação e comunicação na escola. / Kátia Maria de Oliveira Santos. - 2021.

\title{
$143 \mathrm{f}$.
}

Orientador: Professor Dr. Bruno Medeiros Roldão de Araújo.

Dissertação - Curso de Mestrado em Sociologia em Rede Nacional - PROFSOCIO; Centro de Desenvolvimento Sustentável do Semiárido; Universidade Federal de Campina Grande.

1. Ensino de Sociologia - Ensino Médio. 2. Metodologias de ensino de sociologia. 3. Tecnologias da informação e comunicação. 4. Sociologia das tecnologias digitais. 5. Redes sociais e ensino de sociologia. 6. Aparelhamento digital - escolas. 7. Tecnologia e educação. I. Araújo, Bruno Medeiros Roldão de. II. Título.

CDU: $316: 37(043.3)$

\section{Elaboração da Ficha Catalográfica:}

\author{
Johnny Rodrigues Barbosa \\ Bibliotecário-Documentalista \\ CRB-15/626
}




\section{INTERFACE DIGITAL: \\ A SOCIOLOGIA DAS COMUNICAÇÕES DIGITAIS DE INFORMAÇÃO E COMUNICAÇÃO NA ESCOLA}

Dissertação apresentada ao Curso de Mestrado em Sociologia em Rede Nacional - PROFSOCIO - ministrado no Centro de Desenvolvimento Sustentável do Semiárido da Universidade Federal de Campina Grande, como requisito parcial para obtenção do título de Mestre em Sociologia.

BANCA EXAMINADORA:

Prof. Dr. Bruno Medeiros Roldão de Araújo

UAEDUC / CDSA / UFCG

Orientador

Prof. Dr. Valdonilson Barbosa dos Santos

UACIS / CDSA / UFCG

Examinador Interno

Prof. Dr. Walberto Barbosa da Silva

UAEDUC / CDSA / UFCG

Examinador Externo

Trabalho aprovado em: 16 de março de 2021.

SUMÉ - PB 
Dedico este trabalho à minha mãe, Josefa Porfírio (in memorian). Onde estiveres, minha gratidão por sua vida e existência. 


\section{AGRADECIMENTOS}

"Então me invocareis e chegareis a mim para orar e Eu vos darei toda a atenção" (Jeremias 29:12). Por muito tempo as Sagradas Escrituras me revelaram esta promessa e aqui estou eu para concluir um ciclo de minha vida profissional e acadêmica. A gratidão que abunda de meu coração não pode ser traduzida com tanta precisão nas palavras que seguem, mas elas demonstram o processo de formação que passei nos últimos dois anos.

Agradeço ao Senhor que nos escuta com atenção, que nos cuida e torna os projetos de nosso coração em realidade. Toda honra a ti, Deus de infinito cuidado e amor.

Agradeço à minha mãe, Josefa Porfírio (in memorian) por toda sabedoria, todo amor e toda dedicação para que eu me tornasse a mulher que sou hoje. De teu ventre, o calor do amor já me aquecia e sei que continuará aquecendo e dando sentido à minha vida. Obrigada, mãe!

Agradeço ao meu pai, Elias José, por representar a força que sustenta meus dias. A nobreza de um pai reside na atenção com que abdica de seus sonhos em favor dos filhos e filhas. Obrigada, pai!

Agradeço aos meus filhos, Alícia de Oliveira e Guilherme de Oliveira. Minha vida já não é bastante na ausência de vocês. Por tanto amor, por dar novos sentidos e rumos à minha vida, obrigada, filhos!

Agradeço ao meu esposo Alan Araújo por sustentar meus sonhos, acreditar em mim e nunca, nem mesmo por um segundo, me abandonar. Muito obrigada, Alan!

Agradeço aos meus sogros, Pedro Felismino e Maria de Lourdes Araújo por serem presença viva em minha vida, por constituírem os laços de cuidado e amor que nos tornam família. Obrigada, sogros!

Agradeço às minhas irmãs Vanuza de Oliveira e Cleide de Oliveira. Por apoiarem, por dividirem sonhos e a vida. $\mathrm{O}$ amor que nos une é um fio de vida que não tem fim. Obrigada, irmãs!

Agradeço aos meus sobrinhos Catarina de Oliveira e Rodrigo de Oliveira, a quem tanto admiro por suas inteligências e juventude. Vocês me inspiram uma vida melhor. Obrigada, sobrinhos!

Agradeço ao meu único avô vivo, Otacílio. Por sua vida, a quem honro com tanta admiração, e por sua força, muito obrigada, avô! 
Agradeço à minha cunhada Aline Araújo, a quem tenho a alegria de contar como família. Obrigada, cunhada!

Agradeço a todos os familiares e parentes que estão, direta ou indiretamente, em minha vida. Uma família é uma grande rede de amor que se expande e se alarga a cada dia. Sem vocês, não seria quem sou. Obrigada, família!

Agradeço ao meu amigo Diêgo Santana. Por tantos diálogos e partilha, obrigada, amigo!

Agradeço ao prof. Dr. Bruno Medeiros Roldão de Araújo por sua orientação e presença tão sensível neste trabalho. Obrigada por acreditar na pesquisa e nos ajudar a conduzir tudo da melhor forma, mesmo nos momentos mais difíceis de minha vida pessoal.

Agradeço aos professores da banca examinadora, prof. Dr. Valdonilson Barbosa e prof. Dr. Walberto Barbosa. Suas contribuições refinaram nossa pesquisa e a tornaram mais robusta e densa. Obrigada pela disponibilidade de avaliar este trabalho!

Agradeço a todos os professores do PROFSOCIO, Campus Sumé, que, através das disciplinas cursadas, acabaram influenciando o olhar sociológico sobre a pesquisa. Obrigada, professores.

Agradeço à escola onde realizamos a pesquisa, por sua abertura e acolhida, mesmo em tempos de pandemia do novo coronavírus.

Agradeço a Ivonete Ramos, diretora da escola onde a pesquisa foi realizada. Sua generosidade em acolher a pesquisa foi importante para todo o desenvolvimento da pesquisa. Obrigada!

Agradeço aos alunos e professores que se dispuseram gentilmente a participar da pesquisa. Vocês são parte essencial da pesquisa, muito obrigada!

Agradeço à minha amiga Rosana Medeiros por sua amizade, companheirismo e ser disponível sem que preciso. Obrigada, amiga!

Agradeço à Universidade Federal de Campina Grande, Campus Sumé, por ser parte do meu sonho e por permitir esta formação profissional, acadêmica e pessoal.

Agradeço ao município de Sumé - PB, que me acolheu tão generosamente.

Agradeço ao município de Arcoverde - PE, minha casa, minha morada e meu trabalho, a quem sou grata por permitir a realização deste trabalho.

Agradeço à Coordenação de Aperfeiçoamento de Pessoal de Nível Superior CAPES por financiar este estudo. Gratidão! 
"Tornou-se aterradoramente claro que a nossa tecnologia ultrapassou nossa humanidade". 


\section{RESUMO}

Na pós-modernidade, novos valores fundamentam as formas sociais de existir e de transformar o mundo. Esses valores estão presentes na escola enquanto Instituição social que (re)produz normas, significados e ações que direcionam o agir, o sentir e o pensar dos sujeitos na pós-modernidade. Nesse sentido, uma das formas de existência na escola, assim como na sociedade pós-moderna, é dada pela mediação das tecnologias. Essa mediação constrói sentidos outros de se perceber, perceber o outro e estar no mundo. Chamamos essa mediação de aparelhamento digital, onde os sujeitos existem e produzem sentidos de mundo através do uso de tecnologias digitais da informação e comunicação. Em sala de aula, o aparelhamento digital nos leva a questionar os processos de ensino e de aprendizagem. Assim, como problema de pesquisa, trouxemos: quais as implicações do aparelhamento digital para o ensino de Sociologia no Ensino Médio? Nosso objetivo foi compreender quais as implicações do aparelhamento digital para o ensino de Sociologia no Ensino Médio. Propomos, enquanto caminho teórico-metodológico, o uso da Análise Sociológica do Discurso, visto que entendemos os discursos enquanto formas sociais que são internalizados e são modulados pela realidade social, pela construção dos sentidos e significados que estruturam a existência social e que são apreendidos pelos sujeitos nos processos de subjetivação e de socialização. Nosso objeto de pesquisa foi ganhando contornos a partir das contribuições teóricas de Zygmunt Bauman (2001; 2007; 2009), Pierre Bourdieu (1998; 2000; 2011) e Pierre Lévy (1989; 1998). Pelos constructos sociológicos de tais autores, percebemos a necessidade de investigar os processos de aprendizagem no ensino de Sociologia, no Ensino Médio, através do aparelhamento digital. A pesquisa permitiu perceber a necessidade de discutir as implicações do aparelhamento digital no ensino de Sociologia, visto que o que está em evidência é a própria formação humana.

Palavras-chave: Ensino de Sociologia. Tecnologias Digitais da Informação e Comunicação. Aparelhamento Digital. 


\title{
DIGITAL INTERFACE: THE SOCIOLOGY OF DIGITAL INFORMATION AND COMMUNICATION TECHNOLOGIES IN SCHOOL
}

\begin{abstract}
In postmodernity, new values underlie the social ways of existing and transforming the world. These values are present at school as a social institution that (re) produces norms, meanings and actions that guide the actions, feelings and thinking of subjects in postmodernity. In this sense, one of the forms of existence at school, as well as in postmodern society, is given by the mediation of technologies. This mediation builds other meanings of perceiving oneself, perceiving the other and being in the world. We call this mediation digital apparatus, where subjects exist and produce meanings of the world through the use of digital technologies of information and communication. In the classroom, digital equipment leads us to question the teaching and learning processes. So, as a research problem, we bring: what are the implications of digital equipment for the teaching of Sociology in High School? Our objective was to understand the implications of digital equipment for the teaching of Sociology in High School. We propose, as a theoretical-methodological path, the use of Sociological Discourse Analysis, since we understand discourses as social forms that are internalized and are modulated by social reality, by the construction of the senses and meanings that structure social existence and that are apprehended by subjects in the processes of subjectivation and socialization. Our research object was gaining contours from the theoretical contributions of Zygmunt Bauman (2001; 2007; 2009), Pierre Bourdieu (1998; 2000; 2011) and Pierre Lévy $(1989 ; 1998)$. Through the sociological constructs of such authors, we perceive the need to investigate the learning processes in the teaching of Sociology, in High School, through digital equipment. The research made it possible to perceive the need to discuss the implications of digital equipment in the teaching of Sociology, since what is in evidence is the human formation itself.
\end{abstract}

Keywords: Teaching of Sociology. Digital Technologies of Information and Communication. Digital equipment. 


\section{LISTA DE ILUSTRAÇÕES}

Quadro 1 - Subáreas ......................................................... 27

Quadro 2 - Sujeitos participantes da pesquisa ......................... 89

Quadro 3 - Um bom professor ................................................. 90

Quadro 4 - Uso das redes sociais .......................................... 96

Quadro 5 - As redes sociais e seus usos ................................ 101

Quadro 6 - As redes sociais e a construção de laços sociais .... 105

Quadro 7 - $\quad$ O eu nas redes sociais .......................................... 109

Quadro 8 - As redes sociais e o saber .................................... 110

Quadro 9 - As redes sociais e o futuro ................................... 112

Quadro 10 - As aulas de sociologia ......................................... 118

Quadro 11 - Aparelhamento digital e aprendizagem .................... 121

Quadro 12 - Questionário aplicado aos professores .................... 126 


\section{LISTA DE FIGURAS}

Figura 1 - Análise Sociológica do Discurso ................................ 80

Figura 2 - $\quad$ As direções do discurso ......................................... 81 


\section{LISTA DE ABREVIATURAS E SIGLAS}

$\begin{array}{ll}\text { IBICT } & \text { Instituto Brasileiro de Informação em Ciência e Tecnologia } \\ \text { TDIC } & \text { Tecnologias Digitais da Informação e Comunicação } \\ \text { BDTD } & \text { Biblioteca Digital Brasileira de Teses e Dissertações } \\ \text { FINEP } & \text { Financiadora de Estudos e Pesquisas } \\ \text { CNPq } & \begin{array}{l}\text { Conselho Nacional de Desenvolvimento Científico e } \\ \text { Tecnológico }\end{array} \\ \text { MEC } & \text { Ministério da Educação } \\ \text { CAPES } & \text { Coordenação de Aperfeiçoamento de Pessoal de Nível Superior } \\ \text { SESu } & \text { Secretaria de Educação Superior } \\ \text { USP } & \text { Universidade de São Paulo } \\ \text { PUC-RIO } & \text { Pontifícia Universidade Católica do Rio de Janeiro } \\ \text { UFSC } & \text { Universidade Federal de Santa Catarina } \\ \text { MTD-BR } & \text { Padrão Brasileiro de Metadados para Teses e Dissertações } \\ \text { CRV } & \text { Centro de Referência Virtual do Professor } \\ \text { SEEDUC } & \text { Secretaria de Estado de Educação do Estado do Rio de Janeiro } \\ \text { PCN } & \text { Parâmetros Curriculares Nacionais } \\ \text { ASD } & \text { Análise Sociológica do Discurso }\end{array}$




\section{SUMÁRIO}

1 INTRODUÇÃO .................................................................................................................13

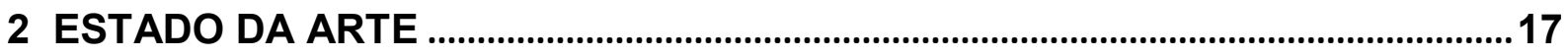

3 REVISÃO BIBLIOGRÁFICA: A PÓS-MODERNIDADE, O SUJEITO E AS INTERFACES DIGITAIS .............................................................................................43

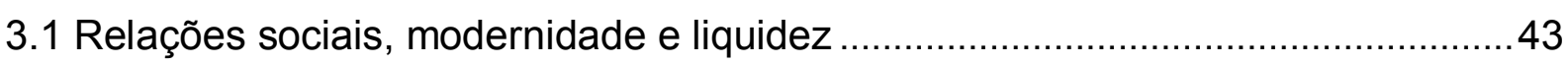

$3.2 \mathrm{O}$ sujeito da modernidade líquida e as sociabilidades modernas .........................48

3.3 Pensando a Cibercultura e outros cenários de aprendizagem a partir da

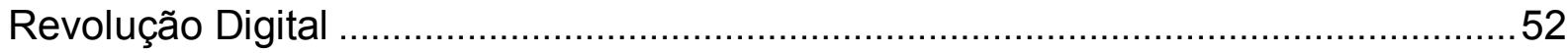

3.4 Cibercultura, ciberespaço e processos de subjetivação ………………....56

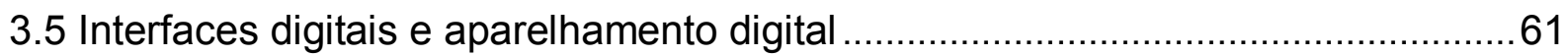

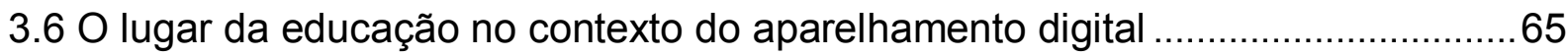

4 FUNDAMENTAÇÃO TEÓRICO-METODOLÓGICA..................................................72

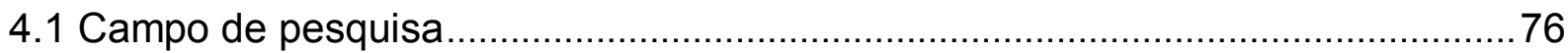

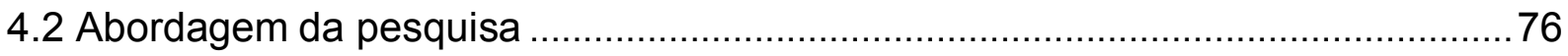

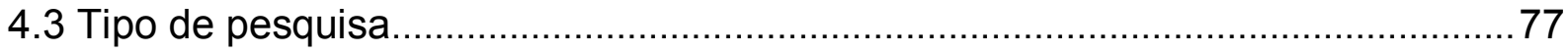

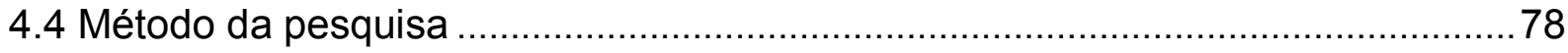

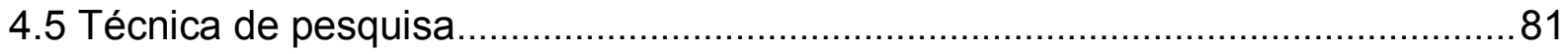

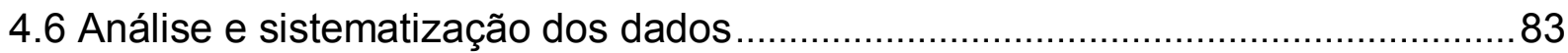

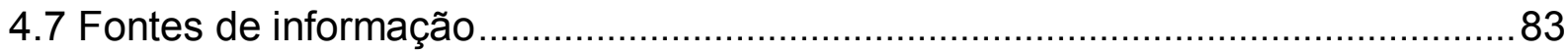

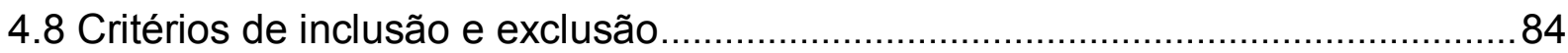

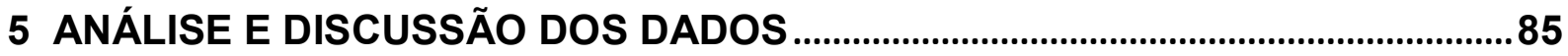

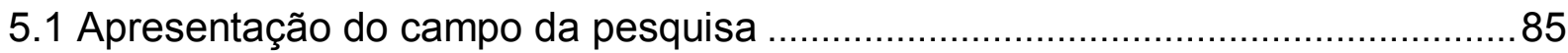

5.2 Os sujeitos participantes e as questões éticas da pesquisa ................................. 88

5.3 Os cenários de aprendizagem: aparelhamento digital e cibercultura no contexto de investigação.

5.4 Formação de novas subjetividades na escola no contexto da pós-modernidade

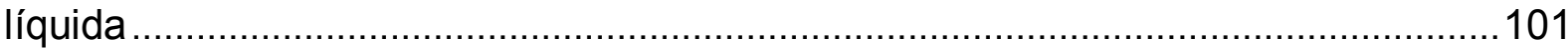

$5.5 \mathrm{O}$ aparelhamento digital, produção do conhecimento e as aulas de sociologia 114

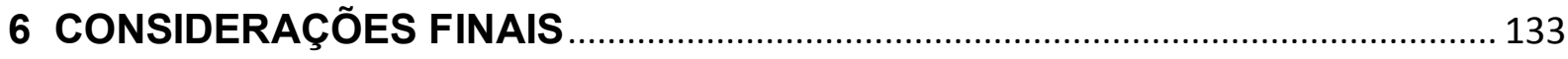

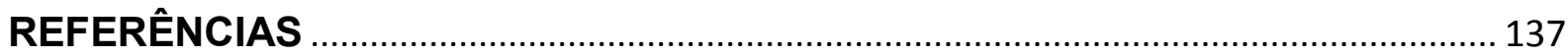




\section{INTRODUÇÃO}

Quando pensamos a escola, lançamo-nos em um movimento de profunda compreensão sobre esta instituição social a partir de sua função, de suas estruturas, de suas singularidades e dos contextos políticos, culturais, estéticos, éticos e filosóficos que atravessam as relações tecidas no chão da escola. Que dizemos com isso? Ora, a escola é instituição onde as relações sociais, as subjetividades e intersubjetividades são forjadas; é também uma estrutura onde o poder circula. Mas como circula esse poder? Como o poder se relaciona com a formação e transformação das subjetividades? Assim, pretendemos dizer que a escola é território institucional que produz e reproduz as relações, o poder e as formas de ser, pensar e sentir na sociedade. Não é território exclusivo, mas é território amplo.

Dito isto, prosseguimos: a escola é instituição social que produz e reproduz poderes, relações e subjetividades e que, fundamentalmente, estabelece valores ou rupturas de valores. Na pós-modernidade, os valores excludentes, redutores, de descarte e objetificação - tão característicos da modernidade líquida e que fundamenta relações também líquidas - são experienciados e vivenciados por meio de pedagogias, metodologias, didáticas e avaliações postas pela escola. Não nos interessa saber se é algo posto intencional ou não intencionalmente; interessa-nos saber que a produção do conhecimento foi influenciada por esses valores.

A tecnologia assume um papel decisivo nas aprendizagens, nas ensinagens e em todos os processos pedagógicos, de modo que os estudantes assumiram como parte de si e parte do processo de produção do conhecimento o aparelhamento digital. Esse aparelhamento digital se dá quando as formas de se relacionar consigo, com o outro e com o mundo acontece através de mídias e outros instrumentos digitais que possibilitam novas subjetividades. Trata-se do que Silva (2006) chama de metaprogramas comunicacionais. Eles servem para filtrar nossas percepções no mundo.

Ao contextualizarmos esses aspectos para as aulas de Sociologia no Ensino Médio, podemos questionar se o aparelhamento digital contribui efetivamente para que os conhecimentos produzidos nas aulas de Sociologia sejam libertadores ou apenas sejam parte do componente curricular. 
Enquanto professora de Sociologia, inquietava-me alguns valores vivenciados e partilhados pelos estudantes. A liquidez das coisas, das relações, das posições de mundo, a falta de compromisso com saberes e conhecimentos que pudessem direcionar novas realidades, levaram-me a questionar o que a escola estava fazendo diante disso. Mais precisamente: em que medida as aulas de Sociologia poderiam contribuir para que houvesse enfrentamentos sobre valores líquidos cada vez mais constantes na vida das pessoas?

Percebi que as subjetividades e as relações sociais, por consequência, estavam sendo afetadas pelo aparelhamento digital. A realidade digital e virtual é inegável. Dela não podemos fugir. Não podemos também demonizá-la, pois faz parte do que podemos entender por progresso. É preciso, contudo, uma reorientação frente ao uso que se faz da tecnologia.

Começo esta justificativa a partir de minhas percepções e do meu olhar empírico sobre o cotidiano nas aulas de Sociologia no Ensino Médio. Se essa disciplina apresenta o potencial questionador de desconstruir tudo que é posto de forma naturalizada na sociedade, então, mais que nunca, é preciso que possamos repensar a quem servem nossa pedagogia, nossa didática, nossa metodologia e nossa avaliação nas aulas de Sociologia.

Assim, cada pesquisa que contesta a escola, especialmente, o ensino de Sociologia, contribui para que haja formação humana, e não apenas o cumprimento curricular. As pesquisas são sempre políticas porque servem a interesses; a neutralidade científica, nas ciências humanas e sociais, já se tornou uma narrativa superada, de modo que devemos repensar sempre a nossa responsabilidade de pesquisador. Para além disso, assumimos, ao questionar o ensino de Sociologia, uma postura docente de preocupação com o mundo e com as transformações sociais.

Ao refletirmos sobre a educação, especialmente fazendo um recorte sobre o ensino de Sociologia no Ensino Médio, precisamos entender alguns tensionamentos sobre a função social da escola e algumas bases da pós-modernidade. A escola e seu papel reprodutor e legitimador das estruturas sociais e das ideologias é uma perspectiva de denúncia que não podemos esquecer.

Se as bases das desigualdades sociais podem ser reproduzidas na escola por meio dos programas de ensino, do currículo, da avaliação, das metodologias, das didáticas e das pedagogias que servem a interesses dos grupos econômicos, culturais 
e sociais dominantes, temos então que contestar e perguntar: o que ensinamos? Para quem ensinamos? Como ensinamos? Por que ensinamos algo?

Essas questões oferecem suporte para entendermos que alguns valores da pós-modernidade podem ser transmitidos e incorporados aos hábitos dos indivíduos pela escola. Valores como descarte, individualismo exagerado, relações líquidas e utilitárias podem ser enfrentados quando recorremos a processos de formação que se coloquem a favor da conscientização dos sujeitos.

$\mathrm{Na}$ pós-modernidade, as tecnologias são meios pelos quais estabelecemos produção de conhecimento no nosso cotidiano. Assim, é válido questionar sobre como os meios tecnológicos estão contribuindo para reprodução ou enfrentamento das desigualdades sociais. Este projeto de pesquisa traz, portanto, o seguinte problema de pesquisa: quais as implicações do aparelhamento digital para o ensino de sociologia no Ensino Médio?

À luz das teorizações que iremos apresentar nesta pesquisa, apontamos duas hipóteses principais para nosso problema de pesquisa, a saber: i) o aparelhamento digital é um modo de se relacionar socialmente e produzir conhecimentos e experiências na modernidade. Ele revela hábitos, sociabilidades, valores e comportamentos dos indivíduos frente ao cotidiano. Pelo aparelhamento digital podemos perceber quais são as visões de mundo dos sujeitos e como eles interagem consigo, com os outros e com o mundo; ii) o ensino de Sociologia quando faz uso do aparelhamento digital pode permitir novos processos de conscientização e de formação de capital cultural. Pode permitir novos posicionamentos sociais. Como nos ensina Freire (1979), a educação é uma prática de liberdade conquanto seja uma aproximação crítica com as realidades e o tecido social. Torna-se então, o próprio processo de conscientização.

Assim, nosso objeto de pesquisa ganha contornos epistemológicos e caminhos metodológicos que convergem para os processos de aprendizagem no ensino de Sociologia, no Ensino Médio, através do aparelhamento digital, sendo esta relação a ser pesquisada.

Como objetivo geral temos: compreender quais as implicações do aparelhamento digital para o ensino de Sociologia no Ensino Médio. Os objetivos específicos são estabelecidos da seguinte maneira: i) caracterizar o aparelhamento digital a partir do conceito de cibercultura e dos novos cenários de aprendizagem; ii) discutir a formação de novas subjetividades na escola no contexto da pós- 
modernidade líquida e iii) identificar em que medida o aparelhamento digital nas aulas de Sociologia no Ensino Médio influencia a produção do conhecimento dos estudantes.

A discussão teórica é fundamentada a partir do conceito de modernidade líquida de Bauman $(2001 ; 2007 ; 2009)$ e de suas influências nas relações sociais, das teorizações sobre cibercultura e outros cenários de aprendizagem de Pierre Lévy $(1989 ; 1998)$ que nos ajudam a pensar o conceito de aparelhamento digital como meio de sociabilidade na escola e as reflexões de Pierre Bourdieu (1998; 2000; 2011) sobre a escola e a educação. 


\section{ESTADO DA ARTE}

Para iniciar nosso estado da arte, traçamos primeiramente um objetivo capaz de conduzir nossas buscas. Não nos interessa quantificar as pesquisas encontradas - apesar de isso ser importante. Assim, elegemos como objetivo desse estado da arte discutir as proposições trazidas pelos autores acerca da relação ensino de sociologia e aparelhamento digital. Nosso trabalho é fundamentado em dois momentos: o primeiro é a busca de teses e dissertações; o segundo é a busca por artigos. Para isso elegemos, conforme a abrangência e reconhecimento acadêmico, duas plataformas de consulta: a Biblioteca Digital Brasileira de Teses e Dissertações e o Portal de Periódicos CAPES/MEC.

O Instituto Brasileiro de Informação em Ciência e Tecnologia - IBICT concebeu, em 2002, a Biblioteca Digital Brasileira de Teses e Dissertações - BDTD. Esta plataforma contou com o apoio da Financiadora de Estudos e Pesquisas - FINEP. Através do Conselho Nacional de Desenvolvimento Científico e Tecnológico - CNPq, do Ministério da Educação - MEC, da Coordenação de Aperfeiçoamento de Pessoal de Nível Superior - CAPES, da Secretaria de Educação Superior - SESu, da Universidade de São Paulo - USP, da Pontifícia Universidade Católica do Rio de Janeiro - PUC-RIO e da Universidade Federal de Santa Catarina - UFSC, foi criado o Padrão Brasileiro de Metadados para Teses e Dissertações - MTD-BR. Assim, a Biblioteca Digital Brasileira de Teses e Dissertações se consolidou como uma iniciativa de grande destaque mundial sobre a disseminação e visibilidades das teses e dissertações defendidas nas Instituições de Ensino Superior (BDTD, 2020).

Ao pesquisarmos o horizonte de discussão e produção científica referente ao objeto de pesquisa a que nos propusemos a pesquisar, traçamos como objetivo discutir a relação entre ensino de sociologia e aparelhamento digital. Optamos, pelo alcance quantitativo e qualitativo da plataforma, por utilizar a Biblioteca Digital Brasileira de Teses e Dissertações para conhecer o que se tem discutido e produzido acerca do aparelhamento digital e do ensino de sociologia no Ensino Médio. Pelo buscador ensino de sociologia, encontramos 2.268 pesquisas realizadas, sendo que 77 estavam na área de educação. Das pesquisas na área da educação, nenhuma discutia o aparelhamento digital. Quando buscamos por aparelhamento digital, não foi encontrada nenhuma pesquisa. 
O que pode nos dizer este achado? Parece que a discussão sobre o ensino de sociologia e o aparelhamento digital é um território vasto, mas que ainda não foi explorado. Ora, as tecnologias e as sociabilidades, bem como as novas subjetividades na contemporaneidade, são temas bem discutidos. Mas, não pensamos tanto em como o ensino de sociologia pode ser afetado pelo aparelhamento digital. Quando isso acontece, a escola, como instituição social, passa a ser questionada sobre a reprodução das ideologias dominantes e também pela legitimação dos valores morais, éticos, políticos, estéticos e cognitivos de uma elite que disputa poder por meio da educação.

De modo que pensar o aparelhamento digital é também (re)pensar o ensino de sociologia enquanto um instrumento de empoderamento e conscientização de mundo ou como um mero componente curricular. Com isso, afirmamos a necessidade de se questionar: a quem serve o ensino de sociologia? O que se ensina é um conhecimento poderoso para libertar as amarras epistemológicas e sociais? Ou o que se ensina é um conhecimento dos poderosos que dociliza a pessoa e forma para manutenção de valores cada vez mais líquidos em uma sociedade que valoriza cada vez mais a objetificação das pessoas e a liquidez das relações?

Importa-nos, pois, através do exercício sociológico de desnaturalizar as coisas, o mundo, as relações e as pessoas, tensionar as relações sociais dentro da escola, especificamente no ensino de sociologia, visto que, uma das bases axiomáticas que sustenta nosso fazer epistemológico, é questionar criticamente a escola e sua potência em criar novos arranjos de poder. Quando outros e novos arranjos de poder são criados a partir de uma visão sobre a responsabilidade pedagógica e educativa da escola na formação de pessoas mais solidárias, enfrentamos alguns valores que estruturam a modernidade líquida.

Resolvemos, então, consultar a mesma plataforma usando os termos ensino médio, sociologia e tecnologias da informação e comunicação ${ }^{1}$. Optamos por não fazer a seleção seguindo um lapso temporal, visto que, pela experiência de busca anterior, as pesquisas mostram-se escassas. Nessa nova consulta, encontramos o total de 20 pesquisas sendo produzidas. Essas pesquisas foram produzidas entre 2001 e 2019.

\footnotetext{
${ }^{1}$ Optamos por usar este termo ao invés de Tecnologias Digitais da Informação e Comunicação por ser um termo mais recente e que implicaria em uma redução de achados.
} 
Das 4 teses encontradas, após a leitura dos resumos, identificamos uma certa aproximação de nossa pesquisa com o trabalho de André Dala Possa. Intitulado Interação comunicacional de estudantes do ensino médio: netnografia para compreensão da nova ecologia cognitiva. Essa tese, defendida em 2018 no Programa de Pós-graduação em Ciências da Comunicação da Universidade de São Paulo, tem o objetivo de descrever a ecologia midiática em vivências de rua e de aprendizagem formal e informal de estudantes de Ensino Médio do Instituto Federal de Educação, Ciência e Tecnologia de Santa Catarina. O autor utilizou-se da netnografia como método de pesquisa.

Para Possa (2018), há um modelo e uma lógica de comunicação fundados a partir do movimento ciberneticista da década de 1940. Então, a filosofia da informação nos mostra uma quarta revolução: o homem como ser informacional e interconectado. Ainda para o autor, há uma ubiquidade tecnológica, ou seja, uma onipresença da tecnologia no nosso cotidiano e a ciência da comunicação assume um lugar especial nessa realidade. A realidade virtual permite novos comportamentos e novas linguagens.

Possa (2018) mostra que a população jovem brasileira que está na educação formal, mais especificamente no Ensino Médio, nasceu permeada de tecnologias digitais. É uma geração que cresceu com o uso de aplicativos, aparelhos digitais e redes sociais. $\mathrm{O}$ autor relaciona esse uso dos dispositivos digitais com a linguagem. A linguagem faz o ser humano desenvolver-se e sair de um estado primitivo.

Em contextos digitais, o sujeito desenvolve outra relação com o ambiente à sua volta. É no contexto líquido, apontado por Possa (2018) que surgem novas ecologias comunicativas que mudam a relação do ser humano com seu corpo, com o trabalho e outras dimensões. O autor chama de digitalização (POSSA, 2018, p. 20) o fenômeno de transformação do mundo em informações tecnológicas que conferem à experiência humana possibilidades até então não imaginadas. Então, ele questiona em que medida a educação tem formado para novas experiências sociais sobre a digitalização.

Para chegar aos seus achados, outro ponto importante foi a adoção da netnografia. $\mathrm{O}$ autor menciona que ela permitiu uma maior leitura sobre as questões de literacia $^{2}$ digitais de mídia e informação. Assim, o estudo apontou que os

\footnotetext{
${ }^{2}$ Literacia tem valor de letramento.
} 
estudantes criam códigos discursivos próprios e novas propostas cognitivas são desenvolvidas a partir da criação desses códigos. Também o estudo apresenta que, se de um lado as redes sociais são limitadas para o fluxo de conteúdos orgânicos e cognitivos, por outro lado os adolescentes sabem respeitar os regramentos dos ambientes. Eles se agrupam, portanto, conforme os interesses de informação.

A pesquisa de Possa (2018) ainda revela que a exposição discursiva dos adolescentes demonstra os valores aceitos ou não, como diversidade de gênero, raça, política-partidária. Contudo, esses valores são mais tímidos quando expostos em espaços abertos (fanpages, intervalos e corredores da escola) e são mais livres nos espaços fechados (grupos de WhatsApp, por exemplo).

Outro ponto importante apresentado nessa pesquisa é que a escola passa a ser uma instituição não prioritária sobre os conteúdos, saberes e mesmo o desenvolvimento de novos discursos informacionais. Sugere pois, o autor, que a escola possa repensar a concepção de currículo, bem como reelaborar novas maneiras de avaliação de saberes e competências.

Contribui essa pesquisa para este projeto de pesquisa a noção do estudar. Para o público pesquisado, estudar é estar on. Isso, para Possa (2018), independe da vontade escolar. O estudante, em seu percurso antropológico, é quem irá decidir e criar sua ecologia midiática para a aprendizagem.

Das 16 dissertações encontradas, selecionamos a partir da leitura dos resumos e das aproximações com o objeto de pesquisa deste projeto, e chegamos ao número de 3 trabalhos. O primeiro trabalho é intitulado $O$ docente do ensino médio e as tecnologias da informação e comunicação: análise de possíveis alterações no processo de trabalho. O trabalho é de autoria de Walas Leonardo de Oliveira e pertence ao Programa de Pós-graduação de Educação da Faculdade de Educação da Universidade Federal de Minas Gerais, defendido em 2007.

Oliveira (2007) parte do pressuposto de que as Tecnologias Digitais da Informação e Comunicação - TDIC são uma realidade da qual não podemos negar e nem fugir. Especialmente na educação, elas têm desempenhado um papel que tem modificado a relação ensino e aprendizagem, docente e discente. Para o autor, apesar dessas transformações, há implicações que precisam ser consideradas. Por exemplo, a existência da geração analógica em um contexto digital. Outra questão é pensar como a escola deve, de modo crítico, responder à essa realidade vivenciada por seus sujeitos digitais. 
Existem professores que exercem seu trabalho de forma deslocada da realidade. Os professores que se aventuram na realidade digital começam a perceber que, diante das TDIC, eles não têm encontrado suporte, seja da academia, seja da escola. Assim, não há como investigar as vantagens e desvantagens do uso das TDIC no ensino (OLIVEIRA, 2007). Lembramos que o ano de publicação do referido estudo demonstra o contexto da época da pesquisa, que não é tão distante, mas que já passou por grandes transformações no cenário sobre as pesquisas com TDIC na educação.

Nisso, Oliveira (2007) propõe uma investigação sobre a repercussão e influências das TDIC na prática docente. Sendo um fenômeno novo, o autor sinaliza para alguns achados da pesquisa, como as TDIC no contexto da escola. Ele mostra que tanto escolas públicas quanto privadas, mesmo aparelhadas com computadores e rede de acesso à internet, a maior dificuldade é a natureza cultural do fenômeno, onde há resistência por parte dos profissionais da educação quanto ao manejo das TDIC para o ensino.

É preciso, na perspectiva teórica adotada por Oliveira (2007), que a escola conceba a integração entre o mundo analógico e o digital. Isso porque a escola, enquanto instituição social, adota diversas tecnologias em seu cotidiano e interior, como a escrita, a linguagem verbal, saberes simbólicos. Todavia, em relação às TDIC, a escola deixa que a cultura extraescolar defina essa integração e traduza essa experiência para a escola.

As TDIC promovem alterações no trabalho docente, tanto na prática de trabalho quanto nos processos de trabalho. Na prática de trabalho, o docente necessita reaprender a lidar com a cultura informacional, com o ciberespaço, com as interações e sociabilidades que surgem a partir das TDIC. Mesmo assim, ele pode adotar uma postura tradicional frente as alterações demandadas pelas TDIC. Essa postura é visível quando ele usa os aparelhos digitais apenas para extrair informações, por exemplo. Já nos processos de trabalho, as TDIC podem otimizar o tempo, a forma de produção de materiais para suporte de aula e a informatização torna-se um processo comum na dimensão da prática docente (OLIVEIRA).

Ao finalizar o estudo, Oliveira (2007) indaga não mais as TDIC na educação e suas implicações no trabalho docente, mas a internet e sua relação com o trabalho docente. Acreditamos, e assumimos essa perspectiva no nosso trabalho, que a 
internet passa a ser um dispositivo de subjetivação, de mediação de sociabilidades e de construção de novas realidades.

Outro trabalho encontrado é a dissertação de Silvana Aparecida Pires Leodoro (2009). Com o título A disciplina Sociologia no Ensino Médio: perspectivas de mediação pedagógica e tecnológica, um diálogo possível. O trabalho faz parte do Programa de Pós-graduação em Educação da Universidade de São Paulo.

A pesquisa apresenta os seguintes objetivos gerais ${ }^{3}$ : investigar as novas relações de ensino-aprendizagem a partir da utilização de tecnologias da informação e comunicação estruturando um modelo de medicação pedagógica à luz dos objetivos pretendidos para a disciplina e explicitados nas Orientações Curriculares Nacionais (OCN); resgatar a história da disciplina Sociologia no Brasil e atualizar importantes pesquisas já realizadas sobre o tema; investigar a noção de interatividade como elemento constitutivo do novo modelo conversacional (pela web) e como ele atua na mediação tecnológica; e investigar a construção do aluno-sujeito da era digital a partir das representações simbólicas que o novo modelo conversacional pode ocultar ou revelar.

A pesquisa de Leodoro (2009) analisou as situações de diálogo e de interação mediadas pelo computador e também pela rede mundial de computadores. A análise acontece em uma perspectiva sociológica e investigou as potencialidades dialógicas que emergem do conhecimento construído a partir dos diálogos virtuais entre alunos e professores.

O trabalho vai na perspectiva de que o compartilhamento de informações através da rede mundial de computadores e a mediação tecnológica são demandas da escola na modernidade. Assim, a comunicação em ambientes virtuais amplia a relação dialógica de construção do conhecimento escolar. O professor assume uma posição de provocador cognitivo e, assim, consegue (re)avaliar as relações estabelecidas no ato de ensinar e de aprender na disciplina de Sociologia (LEODORO, 2009).

A metodologia utilizada por Leodoro (2009), a saber, a pesquisa-ação, contribui para que houvesse a possibilidade de uso e de vivência, por parte do pesquisador, de diálogos educacionais em ambiência virtual, envolvendo a experimentação de correio eletrônico, pesquisa pela internet, uso e análise de filmes em DVD, interações por

\footnotetext{
${ }^{3} \mathrm{~A}$ pesquisa não apresenta um único objetivo geral, mas objetivos gerais e outros objetivos específicos.
} 
meio de $b \log ^{4}$ publicado pela professora, assim como reuniões através do $\mathrm{MSN}^{5}$. Comungamos da opção teórico-metodológica da autora quando se posiciona a favor da experimentação e da vivência da rede virtual de informação. Entendemos que isso permite sentir e pensar de maneira mais próxima possível do fenômeno a ser investigado. A opção metodológica é uma construção que não pode afastar-se da vivência, da experimentação e da construção de uma relação mais íntima com o objeto de estudo.

Leodoro (2009) mostra que o uso das tecnologias de comunicação pode ampliar o espaço-tempo da aula presencial. Isso permite que os objetos da disciplina possam se articular ao cotidiano dos alunos. Também, a autora traz que é necessária a inserção, por parte da escola, do uso das tecnologias e o reconhecimento de suas potencialidades pedagógicas. Nesse sentido, passamos a perceber que há a necessidade de se ouvir os profissionais que estão na docência, na coordenação pedagógica e na direção da escola para entender como se dá o reconhecimento dessa necessidade de inclusão das TDIC no contexto educacional. Por tal motivo, passamos a incluir outros sujeitos participantes da pesquisa no nosso projeto.

Ainda, para Leodoro (2009), as TDIC ampliam a função social dos conteúdos da disciplina e permite uma reflexão sobre a realidade. Há, portanto, uma interatividade enquanto elemento que constrói um modelo de comunicação descentrado e bidirecional. A mediação tecnológica proporciona outras práticas de mediação pedagógica. A dialogicidade, como valor, possibilita que os alunos proponham novos temas para as aulas, realizem novas leituras e interpretações e tenham acesso permanente ao professor.

A pesquisa de Leodoro (2009) evidencia a transformação na arquitetura de poder da sala de aula tradicional, mantida na figura de um professor, de um mestre dotado de todo conhecimento. As TDIC colaboram para construção cooperativa e para o diálogo crítico e reflexivo. Importante, na compreensão da autora, que se não houver a dialogicidade no manejo das TDIC, o conhecimento apenas é partilhado e compartilhado, mas não se torna transformador. Assim, há a necessidade da autonomia do aluno-sujeito-do-conhecimento. É uma leitura freireana sobre as TDIC na relação de aprendizagem e de ensino. Essa concepção se distancia do nosso

\footnotetext{
${ }^{4}$ É um sítio eletrônico em formato de diário que permite publicação de artigos, postagens e publicações.

5 Programa de mensagens instantâneas criado pela Microsoft. Criado em 1999, tal serviço foi desativado em 2003.
} 
propósito porque pretendemos a investigação sociológica sobre o fenômeno, e não uma leitura crítica e social da relação pedagógica.

A autora aponta para a relação educação, TDIC e democracia. Mesmo sendo uma leitura necessária e válida para os tempos atuais, onde vivemos pós-verdades, pós-compreensões e fluidez da informação, focamos nossa atenção na questão de como as subjetividades são influenciadas pelo aparelhamento digital e de como essas novas subjetividades influenciam o Ensino de Sociologia. Nesse sentido, outro caminho apontado por Leodoro (2009) é sobre a legitimidade de educarmos para a linguagem dos meios digitais, educar para a leitura das fontes e disputarmos a disciplina de Sociologia com fins a conceber novos sujeitos na modernidade que rompam com a opressão dos sujeitos na rede. Seguimos esse caminho apontado por Leodoro (2009): entendemos a importância da disciplina de Sociologia como um tipo de formação que consiga pautar novos valores e novas leituras do real em tempos de liquidez.

A última dissertação encontrada foi de Janete Araújo da Silva, publicada em 2013, com o título As tecnologias da informação e da comunicação e o ensino de sociologia nas escolas públicas do Distrito Federal: inclusão digital e capital tecnológico-informacional. O trabalho faz parte do Programa de Pós-graduação em Sociologia da Universidade de Brasília. O objetivo do trabalho é compreender como as condições materiais e sociocognitivas para a construção e acúmulo de capital tecnológico-informacional nas escolas públicas do Distrito Federal tornam possível a Inclusão Digital plena e o uso de TDIC na prática pedagógica de Sociologia.

O trabalho de Silva (2013) trata de investigar as condições materiais e sociocognitivas que colaboram para o acúmulo e manutenção do capital tecnológico e informacional entre professores e estudantes de instituições escolares. Para essa investigação, a autora utiliza a categoria de TDIC como fonte de análise. Ainda faz um recorte de campo, optando pelas escolas públicas do Distrito Federal.

Interessa-nos, na pesquisa de Silva (2013), compreender como os recursos tecnológicos que mediam o ensino e a aprendizagem nas aulas de Sociologia contribuem para a construção e o acúmulo de capital tecnológico e informacional. A autora avança e trata da inclusão digital plena nessa discussão como fruto desse processo. Fazendo uma análise marxista, a autora aponta para uma nova etapa de incremento social no interior do modo de produção capitalista, uma fase social e 
econômica chamada de capitalismo informacional. Essa fase pode ser vista no sistema educacional como um eixo integrador e definidor das estruturas sociais.

Nesse cenário, o desenvolvimento social se relaciona às TDIC e essas se apresentam como artefatos da cultura material. Constituem-se diretamente úteis para o estilo de vida das sociedades capitalistas informacionais. As TDIC são, para Silva (2013), cultura material. É desse modo que as condições de uso e acesso às TDIC configuram um tipo de estratificação social nas sociedades capitalistas informacionais. O Ensino Médio, nesse contexto, ganha força de uma formação instrucional capaz de regular a posição social do indivíduo, uma vez que a presença tecnológica é cada vez maior no cotidiano das pessoas, especialmente na escola.

Para Silva (2013), as escolas que apresentam melhores condições materiais formam estudantes tecnicamente melhores quanto ao nível de capital tecnológico e informacional. Esse principal achado da pesquisa leva a autora a questionar o papel do sistema educacional na formação do capital tecnológico e informacional na vida dos estudantes. Ainda a leva a refletir sobre o tipo de inclusão digital que acontece nas escolas públicas de Ensino Médio do Distrito Federal.

As escolas públicas necessitam de pensar processos formativos que possibilitem a autoria de recursos e conteúdos digitais dentro do cotidiano escolar. Minimamente, as escolas públicas devem priorizar a apropriação qualitativa de recursos tecnológicos produzidos fora da escola. Isso porque levaria a formação de estudantes que podem apresentar melhores condições para o exercício da cidadania e das atividades produtivas em um contexto capitalista informacional (SILVA, 2013).

Após a busca por teses e dissertações, optamos por encontrar um horizonte mínimo sobre o que se tem produzido nos artigos. Assim, consultamos o Portal de Periódicos CAPES/MEC. Nele optamos por buscar pelos termos: ensino de sociologia e tecnologias da informação e comunicação, acreditando que tais termos revelam caminhos possíveis da construção do nosso objeto de pesquisa. Optamos ainda pelas publicações apenas em português. Consultamos o que se tem produzido na última década sobre o ensino de sociologia e as tecnologias digitais da informação e comunicação. Assim, encontramos 148 artigos produzidos. Diante do tamanho da produção e do tempo disponível pela pesquisa, lemos os títulos e os resumos dos artigos para encontrar aqueles que se aproximam do nosso objeto de pesquisa. 
O resumo tem a finalidade de divulgar com mais abrangência os trabalhos acadêmicos. Garrido (1993, p. 5) nos diz:

\begin{abstract}
Além da indicação bibliográfica de cada trabalho, acrescentou-se um resumo, de caráter informativo, para promover a divulgação e facilitar o acesso a esses estudos. $O$ crescimento da literatura científica transformou os resumos em instrumentos indispensáveis, na medida em que sua inserção em catálogos e bases de dados agiliza, em muito, a atividade de seleção em busca bibliográfica de todos aqueles que se dedicam ao estudo e à pesquisa. Para que desempenhem este importante papel é necessário, no entanto, que sejam objeto de elaboração cuidadosa.
\end{abstract}

A cautela de Garrido (1993) quanto ao resumo é que um resumo para ser bem elaborado, tecnicamente, precisa conter: objetivo de investigação, metodologia e/ou procedimentos, teóricos, método de tratamento dos dados, resultados e conclusões. O que a realidade mostra é que os resumos mostram motivos implicados e diversos que os elaboram. Assim, a seleção e organização da pesquisa através do resumo é sempre multifacetada e resultadas de diferentes operações.

Recorremos, pois, à reflexão de Ferreira (2002, p. 264): "É possível traçar um determinado 'estado da arte' lendo apenas resumos?". Essa simples questão é repleta de complexidade e seguimos o caminho da autora para responder tal questionamento. Devemos, primeiramente, saber o que pretendemos com o estado da arte. Temos que indagar sobre o resumo: ele será objeto de estudo? Fonte de estudo? Estamos aceitando a heterogeneidade dos resumos? Devemos ignorar a leitura na íntegra das pesquisas encontradas? Devemos então, seguir dois caminhos possíveis: o primeiro é a traçar objetivo para nosso estado da arte. O segundo caminho é inventariar a produção e observar as aproximações com nosso objeto de pesquisa.

Ferreira (2002) ainda nos ensina que o pesquisador enfrentará dificuldades na leitura dos resumos, dada a ordem heterogênica que fundamenta a sua elaboração. Assim, "A organização do material que tem diante de si pressupõe antes de tudo uma leitura que ele deve fazer não só das indicações bibliográficas e dos títulos dos trabalhos, mas principalmente dos resumos" (FERREIRA, 2002, p. 265). Nesse sentido, traçado o objetivo do nosso estado da arte, começamos a inventariar a produção. Focamos nossa atenção em ler os títulos e os resumos para classificar a pertinência ou não com nossa pesquisa. Após classificar e agrupar os trabalhos encontrados, realizamos o trabalho de leitura integral dos trabalhos encontrados. 
Do quantitativo de 148 artigos produzidos, e após leitura dos títulos e resumos, identificamos aqueles do campo da educação, que estavam distribuídos em subáreas, da seguinte forma:

Quadro 1 - Subáreas

\begin{tabular}{|l|c|}
\hline \multicolumn{1}{|c|}{ SUBÁREA } & QUANTIDADE \\
\hline Matemática & 2 \\
\hline Promoção & 2 \\
\hline Pesquisa Qualitativa & 2 \\
\hline Portugal & 2 \\
\hline Mídias digitais & 2 \\
\hline
\end{tabular}

Fonte: a autora (2020).

Esse quadro pode nos mostrar que a relação mais específica entre o ensino de sociologia e o uso de TDIC nestas aulas não foram levadas em consideração no horizonte de produção. Podemos perceber a necessidade de se pensar pesquisas a partir desse objeto de investigação. Mais ainda, quando pensamos que as redes sociais e as TDIC são dispositivos que atuam e direcionam a construção de subjetividades e de outras sociabilidades. Talvez, as implicações do aparelhamento digital, fenômeno advindo das TIDC, não foram tão percebidas porque ele chegou “[...] silenciosamente, por assim dizer, despercebida pelos sociólogos, que, sem questionar, continuam a coletar dados de acordo com as antigas categorias" (BECK; GIDDENS; LASH, 1995, p. 14).

O fenômeno do aparelhamento digital, especificamente quando nos referimos ao ensino de sociologia, assume, nas palavras de Giddens (1991) e Goffman (2010), um "compromisso sem rosto". Isso porque a mediação tecnológica possibilita a impessoalidade. Ainda: a mediação tecnológica, pelo princípio da impessoalidade, permite trocas simbólicas, ou seja, "meios de intercâmbio que podem ser 'circulados' sem ter em vistas as características específicas dos indivíduos ou grupos que lidam com eles em qualquer conjuntura particular" (GIDDENS, 1991, p. 30).

Nesse sentido, pensamos o aparelhamento digital como um caminho que sinaliza outras sociabilidades na pós-modernidade. Simmel (1983, p. 168) exprime a sociabilidade como um valor na sociedade e um constante exercício que se caracteriza "por um sentimento, entre seus membros, de estarem sociados, e pela satisfação derivada disso". Os indivíduos interagem e fazem trocas simbólicas que estruturam seus sentidos de mundo, assim, "é compreensível que a pura forma, por assim dizer, a inter-relação interativa, suspensa, dos indivíduos seja enfatizada de maneira mais vigorosa e efetiva" (SIMMEL, 1983, p. 169). É um processo de interação 
suspensa que dispensa qualquer motivação. Assim, nada se espera além de exercitar o estar junto com os outros e as satisfações que daí provêm, de modo que os vínculos sociais são elaborados com propósitos subjetivos e objetivos alheios a si, promovendo uma ação recíproca.

Dos 10 trabalhos encontrados, selecionamos 7 que dialogam, direta ou indiretamente com nosso objeto de pesquisa. Diante do exposto, começamos a analisar e pensar o que as produções indicam até aqui. O primeiro artigo, de autoria de Belmira Oliveira Bueno e Eliana Scaravelli Arnoldi (2012), foi encontrado na Zona Próxima, Revista del Instituto de Estudios em Educación Universidad del Norte. Esse trabalho trata da formação de professoras de Ensino Fundamental I e as relações estabelecidas com a leitura e a escrita. O objetivo da pesquisa foi problematizar o uso das tecnologias digitais da informação e comunicação na formação docente. A discussão teórica é fundada nas teorias da história cultural de Chartier e da sociologia da cultura de Bourdieu e Lahire. Foram realizadas observações diretas, entrevistas e análise documental; o método foi a abordagem etnográfica.

No trabalho, Bueno e Arnoldi (2012) examinam as formas de (re)apropriação das práticas de leitura e escrita que ocorrem dentro de um programa de licenciatura semipresencial que é desenvolvido dentro do estado de São Paulo. As autoras buscaram compreender e indagar as relações que as professoras estabelecem com as práticas, quando na verdade elas estão em posição de aprendizes. O suporte eletrônico, assim como os caminhos de socialização escolar e profissional e o capital adquirido são caminhos que indicam, para as autoras, as práticas docentes.

A leitura e a escrita são práticas culturais variadas e inscritas de formas diferentes no tempo, sendo criadas e recriadas dentro e fora da escola. As TDIC diversificaram com profunda rapidez as práticas culturais da leitura e da escrita, principalmente quando provocaram mudanças paradigmáticas de representações sobre a escola. Diante da formação continuada em serviço, a história cultural mostra, dentro da proposta de investigação, que, a relação que as professoras estabelecem com a leitura e a escrita fundamenta-se em um processo que as colocam em posição de aprendizes (BUENO; ARNALDI, 2012).

O que as autoras nos apresentam são as estratégias que são utilizadas pelas professoras para lidar com o suporte impresso e o eletrônico para conceber os percursos de socialização escolar e profissional, que implica na aquisição do capital cultural. Citando Chartier e Roche, Bueno e Arnaldi (2012) enfatizam que o suporte 
material e a produção de sentido por meio dos protocolos de leitura têm possibilitado maior discussão sobre os textos impressos e os textos eletrônicos. Assim, as autoras advogam a necessidade de ser visibilizar as diferenças entre ambos os textos e as práticas culturais de leitura e escrita, visto que as competências, que são diferentes para os suportes impressos e eletrônicos, influenciam aprendizados particulares. Concordamos, pois, com as autoras, pois baseando-se em Lévy (2000), entendemos que a cibercultura cria diferentes cenários de ensino e de aprendizagem.

Além disso, o estudo das autoras evidencia as práticas docentes e suas relações com as situações de formação em serviço. As autoras colocam que um mesmo texto é apropriado de formas diferentes por seus leitores, o que requer outras posições de formação docente. Do mesmo modo, citando Bourdieu, as autoras relacionam o suporte material e o capital cultural dos aprendizes e praticantes da leitura e da escrita. Para Bueno e Arnaldi (2012), há uma suposição sobre o largo uso da escrita digital que não é mais dissociado da escrita manuscrita. Os processos de aprendizagem são novos e não lineares, ainda pouco conhecidos. Tais processos precisam ser conhecidos para se repensar a formação de professores e as práticas de alfabetização no ensino fundamental.

Assim, as novas tecnologias e seus impactos sobre a cultura escolar requerem um olhar sobre o cotidiano, sobre a vida e o trabalho dos professores. O cotidiano é o território sociopolítico, uma construção social tecida em lutas e embates, é uma fabricação que permite ver a escola e suas produções, assim como as maneiras de fazer, ou seja, as práticas.

À guisa de conclusão, as autoras trazem algumas novas questões a partir de seu estudo, como:

\footnotetext{
Em que medida tem havido transformações mais efetivas nas práticas de leitura e escrita das professoras, em seus habitus leitores e escritores, tomando-se por referência suas práticas pedagógicas em sala de aula hoje? De que modo os aparatos eletrônicos e as TIC entraram em cena na vida pessoal e profissional dessas professoras? Qual o papel que a escola, o sistema escolar e as políticas educacionais jogam nesse processo, seja na transformação ou no desenraizamento da leitura e da escrita? De que modo a socialização familiar e escolar dessas professoras teria contribuído para a continuidade ou descontinuidade dessas transformações? Quais seriam as potencialidades para a socialização profissional de um programa como o PEC Formação Universitária, que investiu em práticas diárias e diversificadas de leitura e escrita? (BUENO; ARNALDI, 2012, p. 140).
}

Ora, esses questionamentos problematizam a formação de professores e suas sociabilidades profissionais. Vemos, portanto, como as tecnologias digitais da 
informação e comunicação, ao serem utilizadas em sala de aula para a aquisição dos processos de leitura e escrita, permitem uma nova construção do cotidiano e das práticas culturais, reverberando até mesmo na formação de professores.

Avançamos agora para a análise do trabalho intitulado Centro de Referência Virtual do Professor - CRV: portal de apoio didático pedagógico para o professor de sociologia. Este artigo, publicado pela Revista Brasileira de Sociologia em 2014, é de autoria de Elisabeth da Fonseca Guimarães e de Elaine Gonçalves Alves. O trabalho analisa a utilização de um portal educacional da Secretaria de Estado de Educação de Minas Gerais. O uso do portal Centro de Referência Virtual do Professor - CRV por parte dos docentes de sociologia das escolas públicas de Uberlândia passa a ser o objeto de investigação do referido trabalho. Fundamenta-se na discussão sobre as tecnologias digitais da informação e comunicação e as práticas docentes na cibercultura. Esse portal auxilia o trabalho docente na medida em que oferece atividades didático-pedagógicas, mas que, para as autoras, está sendo subutilizado.

Para Guimarães e Alves (2014), a conscientização docente sobre as TDIC é um ato necessário, visto que são instrumentos que podem auxiliar as atividades docentes. Assim, é preciso que haja reflexão sobre como elas podem contribuir para eficiência no ensino. Ainda, a prática na sala de aula é um desafio que pode ser mais bem manuseada se houver uso das tecnologias digitais da informação e comunicação.

As autoras defendem a existência de uma nova cultura, uma cultura digital que o contexto educacional não pode negar. Sendo assim, um dispositivo que faz parte da cultura digital e que surge no cotidiano dos professores investigados é o portal educacional, o CRV. Esse portal, de modo mais pragmático, disponibiliza informações institucionais que subsidiam a atividade didático-pedagógica docente dos professores de sociologia no ensino médio.

Guimarães e Alves (2014) discutem as TDIC a partir de Kenski e Lévy. O conceito de tecnologia, para elas, diz respeito a um conjunto de conhecimentos e princípios científicos que orienta uma ação. As autoras também apresentam as TDIC como um fator de mudança nas relações sociais, nas vivências e experiências.

Ao contextualizar as TDIC na escola, as autoras trazem Ponte para indicar três conceitos de inserção das TDIC no cotidiano escolar, a saber: i) a alfabetização informática, ii) ensino assistido por computador e seu uso como ferramenta e iii) as TDIC como ferramenta de trabalho. Outro destaque no trabalho analisado é sobre os nativos digitais, que são as pessoas nascidas a partir dos anos de 1980 e que estão 
habituados desde criança aos conteúdos digitais e experimentam a comunicação instantânea. Tais jovens revelam a geração da cibercultura. São cibernativos porque desconhecem o mundo sem a internet, por exemplo.

Citando Prenski, as autoras anunciam uma geração que lida diretamente com os cibernativos, mas que não os são: os imigrantes digitais. Uma boa parte dos docentes são imigrantes digitais, ou seja, não nasceram no advento da internet e das novas tecnologias, mas que adotando-as, fazem uso no cotidiano e muitos tornam-se entusiastas. Uma parte dos imigrantes digitais, ao contrário, são compulsórios, pois atendem às exigências e demandas da cibercultura.

Importante percebermos, como trazem as autoras do estudo, que há um comportamento diferente entre os nativos e os imigrantes digitais. A construção do conhecimento, por exemplo, passa por uma dinâmica do processo de ensino e aprendizagem que é readequada com vistas às mudanças tecnológicas e as demandas da cibercultura. Se por um lado os estudantes fazem uso das TDIC como meio de comunicação, de interação social e de participação na realidade virtual, por outro lado os professores utilizam as TDIC para auxiliar os processos de ensino e aprendizagem.

Esse ponto trazido pelas autoras é importante para entendermos certos embates e dificuldades de comunicação que surgem no processo de aparelhamento digital. Entendemos assim, que os objetivos e usos do aparelhamento digital, por parte dos estudantes e por parte dos professores, podem ser divergentes. A adaptação é fundamental para que haja uma boa comunicação entre professores e estudantes no que concerne às TDIC. A educação, para Guimarães e Alves (2014), deve adaptar-se aos avanços tecnológicos e apropriar-se, criticamente, dos novos meios de comunicação.

As autoras realizaram entrevista com 7 professores de sociologia das escolas públicas de Uberlândia. Desse quantitativo, todos afirmaram possuir computador em casa com acesso à internet. O uso da internet é frequente e todos se consideraram aptos para usar a tecnologia na escola. Sobre a existência do portal CRV, 5 conhecem e 2 desconhecem a interface virtual. Os que não conhecem estão há menos tempo na rede estadual de ensino. A finalidade do acesso ao portal, para os professores que conhecem o portal, é encontrar suporte didático que possa auxiliar no planejamento das aulas. 
Diante disso, as autoras concluíram que a utilização do portal é relacionada com o uso das TDIC, o nível de conhecimento para manejar ferramentas digitais e o uso que fazem de computador e internet para as práticas docentes e outras práticas sociais. Apesar do CRV apresentar conteúdos e informações confiáveis para melhoria do trabalho dos professores de sociologia, ainda assim é subutilizado. A falta de divulgação por parte da Secretaria de Estado de Educação de Minas Gerais acaba interferindo no uso do portal.

O próximo artigo analisado foi o trabalho de Valmaria Lemos da Costa Santos e de José Erimar dos Santos. De título As redes sociais digitais e sua influência na sociedade e educação contemporâneas e publicado em 2014 pela Revista Holos, do Instituto Federal de Educação, Ciência e Tecnologia do Rio Grande do Norte. O objetivo do trabalho é refletir sobre a presença e influência das redes sociais digitais na sociedade e educação, buscando identificar sua importância enquanto ferramenta de comunicação e informação, bem como aspectos ideológicos inerentes a esse fenômeno.

Trata-se de uma pesquisa de cunho exploratório, que entrevistou e aplicou questionário em usuários e docentes de uma escola pública na zona urbana de uma cidade no Rio Grande do Norte. O problema de pesquisa apresentado foi: qual a influência das redes sociais digitais na sociedade e na educação contemporâneas? A discussão teórica parte de autores como Raquel Recuero, Pierre Lévy, Milton Santos e Manuel Castells.

Para os autores, seguindo a perspectiva de Milton Santos, é extremamente necessário contextualizar a aprendizagem às realidades política e socioeconômica em que se vive. Exige, portanto, um trabalho docente que seja capaz de repensar a sociedade, um profissionalismo comprometido com a dedicação e o esforço de superar as dificuldades da profissão, além de uma consciência de época. A técnica da informação, da cibernética, da informática e da eletrônica representam uma nova época. As redes sociais digitais são fruto dessa época, assim, é preciso uma reflexão sobre o que elas podem na sociedade e na educação.

Santos e Santos (2014) questionam as consequências na realidade socioespacial do poder das redes sociais digitais. Eles refletem os aspectos ideológicos que possibilitam novas maneiras de participação na sociedade, assim como as trocas simbólicas de informações, os encontros e a disponibilização dos pertences por meio dos canais digitais. Tudo isso possibilita nossos sistemas de ação. 
O período pós-Segunda Guerra Mundial é cenário propício para a produção de novos símbolos, sentidos e significados humanos. A técnica, a ciência e a informação são componentes que acabaram formando os novos espaços geográficos e as sociedades contemporâneas (SANTOS; SANTOS, 2014). Comungamos o mesmo pensamento com os autores, uma vez que a pós-modernidade é palco da cibercultura e demandou novas formas de sentir, agir e pensar na sociedade.

Santos e Santos (2014), apoiando-se na reflexão de Milton Santos, trazem que a informação é quem define as novas realidades espaciais. Essa informação é difundida por computadores, aparelhos celulares e outros canais eletrônicos e digitais. A realidade passa a ser configurada pela ciência, pela tecnologia e pela informação. É, pois, o período das novas redes técnicas, de novas relações sociais que permitem a circulação horizontal de ideias, mensagens, pessoas e mercadorias em um ritmo energicamente acelerado. Prioriza-se a interconexão, a comunicação sincrônica. Acontece, que esse ritmo necessita de aparatos técnicos, científicos e informacionais, seja nos lugares, seja na vida das pessoas.

Ainda, para Santos e Santos (2014), novos comportamentos e novas necessidades sociais surgem com a realidade socioespacial. Enquanto os autores relacionam a realidade socioespacial a tais comportamentos, inferimos que o aparelhamento digital, por si mesmo, já é fator determinante para novas sociabilidades e a formação de novas subjetividades na pós-modernidade. Para eles, as redes sociais digitais estão presentes massivamente no dia-a-dia e dinamizam novos saberes, novos conhecimentos e identidades. Assim, lançam mão do conceito de sociedade em rede, que é pautada pelas redes sociais e que demanda um espaço virtual. Essa sociedade em rede influencia o processo de ensino e aprendizagem. Voltamo-nos a concordar com os autores sobre a influência dessa sociedade nas questões de ensinagem e aprendizagem.

Os dados apresentados pelos autores mostram que a maioria dos usuários das redes digitais é composta pelas mulheres. Os autores atribuem ao maior tempo de ociosidade que dispõe a mulher em relação ao homem perante o mercado de trabalho. Aqui discordamos, visto que entendemos que os autores não consideraram o tempo de trabalho doméstico demandado pela mulher em uma sociedade sexista como a nossa. Prosseguindo com os dados, os autores identificaram quem a juventude é a camada populacional que mais faz uso das ferramentas de comunicação digital. Sobre o grau de escolaridade, a maioria dos usuários das redes sociais digitais estão ou já 
cursaram o ensino superior, chegando a $87 \%$, e os $13 \%$ estão ou já concluíram o ensino médio. Evidente que, as redes sociais sempre existiram, de um modo ou outro, centradas em diversos fins e formação, mas o que se torna novidade são as redes sociais digitais.

Para Santos e Santos (2014), as redes sociais digitais oportunizam e encaminham para novas espaços de relações. Mesmo assim, apesar da busca por perfis, os autores mostram que $89 \%$ das pessoas buscam por se relacionar na rede com aqueles que tem vínculos no cotidiano. As afinidades definem as relações e as buscas. Isso quer dizer que as redes sociais digitais funcionam como extensão das relações estabelecidas no cotidiano.

Sobre o conteúdo publicado nas redes sociais digitais, $51 \%$ dos entrevistados optam por notícias em geral, 31\% por conteúdos de entretenimento, $7 \%$ optam por conteúdos acadêmicos e $11 \%$ por conteúdos diversos dos apresentados. Já sobre a leitura, $6 \%$ preferem ler notícias em geral, 15\% têm preferência por entretenimento, $8 \%$ optam por ler assuntos acadêmicos e $8 \%$ sobre leituras diversas. Citando, Lévy, os autores falam da relação todos-todos, que para o sociólogo é o fenômeno ocasionado em função de uma cegueira, onde os indivíduos não analisam e nem refletem o que é publicado, apenas aglutinam informações.

Os autores reforçam, através da pesquisa, que, apesar de as informações estarem ao alcance de todos, elas são destinadas para grupos específicos. Há guetos que se formam nas redes sociais digitais. Sejam de estudantes, de religiosos ou profissionais. Esses e outros tantos grupos existem em função de uma fronteira nas redes sociais digitais. Assim, a comunicação é uma ferramenta para um determinado território, já que os grupos funcionam em função de um interesse, de um limite e da possibilidade das relações sociais dentro dele. São, portanto, espaços de poder e de controle.

As redes sociais digitais, quando pensadas para além do espaço virtual e como influencia o processo de ensino e aprendizagem, são, para Santos e Santos (2014), resultado das TDIC na escola. Elas, as redes sociais digitais, permitem, dentre tantas coisas, a comunicação e a informação imediata, conforme o interesse de quem as usam.

Os autores, contudo, não conseguem identificar se elas são dinamizadoras de novos conhecimentos. Alegam que as redes sociais possibilitam a informação, a comunicação e o lazer, mas, na lógica das relações sociais, elas desafiam as práticas 
de ensino e aprendizagem, disseminam valores e atitudes homogeneizantes, que resultam em mudanças de pensamento e de comportamentos. Dito de outra forma: desenvolvem identidade coletiva julgada pelos autores como sendo do tipo negativa. Negativa porque estando em um ambiente - a escola - que é plural, elas deveriam estimular uma contrarracionalidade, capaz de romper com o domínio de uns sobre os outros e do pensamento individual que torna todos em um.

É justamente aqui que divergimos com maior profundidade de Santos e Santos (2014). Não acreditamos que as redes sociais possibilitem a negação de uma identidade plural; na verdade, afirmamos que elas possibilitam a formação de novas subjetividades e que preza pelas identificações, marcas transitórias e não estáticas, que ligam as pessoas e os interesses em comum. Acreditamos ainda que, as redes sociais digitais, permitem sociabilidades heterogêneas, na medida em que entende os diversos grupos que estão nelas e que se intercruzam.

Em convergência com os autores, entendemos que a informação e a comunicação, no período em que vivemos, são realidades urgentes que não se podem mais negar, especialmente no campo da educação, na vida de professores que buscam por novas estratégias de ensino e na vida dos estudantes que utilizam as redes sociais digitais como formas de estar e de ser no mundo.

Trazemos assim, a conclusão de Santos e Santos (2014) ao final do seu estudo: i) as redes sociais digitais permitem diversos objetos comunicacionais, como computadores, celulares e outros; ii) essas redes criam novos espaços sociais de relacionamento; iii) esses espaços geram outras maneiras de participação política, novas formas de entretenimento, contato social, etc.; iv) há a necessidade urgente em se discutir nos ambientes formais de ensino as estratégias de ensino por meio das redes sociais digitais, visto que diversos aspectos da existência humana confluem nesses espaços.

O próximo trabalho analisado, encontrado após a busca na Periódico CAPES, foi Proposta de um modelo de e-Learning social, de autoria de José Martins, Ramiro Gonçalves, Vítor Santos, Manuel Pérez Cota, Tiago Oliveira e Frederico Branco, publicado na Revista Ibérica de Sistemas e Tecnologias da Informação em 2015. O objetivo do trabalho é identificar uma base comum que pudesse suportar um curso de e-learning implementado sobre uma rede social. Trata-se de uma revisão bibliográfica que partiu da compreensão cada vez maior de implementação de processos de aprendizagem sociais e colaborativos. 
Os autores apresentam, após sua fundamentação teórica, um modelo de avaliação de aprendizagem projetado para ser aplicado sobre cursos de e-learning. Contudo, o que nos interessa na análise desse trabalho é encontrar direcionamentos sobre a relação redes sociais e processos de ensinagem e aprendizagem.

Nessa perspectiva, o que os autores apresentam quanto à imbricação das redes sociais nos cenários de ensinagem e aprendizagem é que: i) há bons exemplos de tecnologias utilizadas em atividades de aprendizagem, como uso de ferramentas de criação, gestão e suporte de atividades e ambientes virtuais de aprendizagem. Apesar de existir um conjunto de variáveis que afetam o uso das redes sociais nos processos de ensino e aprendizagem, há, decerto, experiências que desenvolvem atividades de ensino baseadas nas redes sociais e essas experiências têm influenciado o trabalho docente. ii) Pode-se desenvolver recursos nas redes sociais que combinem a familiaridade dos alunos e um programa curricular que passa a ser desenvolvido no ambiente virtual. Isso permite maior dinâmica, colaboração e interação entre os indivíduos. Assim, um caminho possível para isso é: avaliação diagnóstica inicial sobre os conhecimentos dos alunos, desenvolvimento de atividades de aprendizagem ativa, colaborativa e cooperativa, e por fim, avaliação de aprendizagem final. Vemos, nesse sentido, que é possível utilizar as TDIC e as redes sociais a favor do ensino. iii) As avaliações de aprendizagem final necessitam da utilização de tecnologias, visto que a aprendizagem se deu neste cenário.

Interessante perceber que os autores demonstram que o professor tem papel ativo na incorporação das TDIC e/ou das redes sociais nos processos de ensino. Caminhos possíveis de aplicar as tecnologias em favor da aprendizagem são construídos quando o professor assume uma posição de se abrir para as TIC.

Avançamos e analisamos o artigo Educação de Jovens e Adultos e novas tecnologias da informação: uma abordagem educacional, de autoria de Cristiana Barcelos da Silva, Carlos Henrique Medeiro de Souza e Gerson Tavares do Carmo. Esse trabalho foi publicado em 2016 na revista Holos. O objetivo do trabalho foi compreender como os professores da Educação de Jovens e Adultos - EJA se posicionavam frente ao desafio da utilização das tecnologias digitais da informação e da comunicação na prática educacional.

Os autores partem do princípio de que a instituição escolar é apontada como lócus de estudos e análises de fenômenos educacionais. Após uma proposta de programa chamada Nova EJA, da Secretaria de Estado de Educação do Estado do 
Rio de Janeiro - SEEDUC, os autores perceberam a necessidade de se (re)pensar o uso das TDIC nas escolas. Para isso, aplicaram questionários que foram analisados na perspectiva dos estudos de Lévy sobre o novo papel do professor e das competências e habilidades necessárias à prática docente de Tardif.

O ponto de partida do trabalho analisado foram as características dos professores do Programa Nova EJA. Ora, esse programa elegia a utilização de TDIC para fins educacionais no ambiente escolar. Já em 1996, trazem Silva, Souza e Carmo (2016), os Parâmetros Curriculares Nacionais - PCN's recomendavam no Brasil o uso de tecnologias. Para isso, elas deveriam estar inseridas nos currículos e nas disciplinas, consideradas, portanto, instrumentos de aprendizagem na educação escolar. Algumas diretrizes, desse tipo, conduziram e influenciaram a prática docente. Mas, para os autores, foi mesmo na prática e na relação docente-discente que as TDIC emergem com força no contexto da educação.

A sala de aula passou a ter uma infinidade de equipamentos multimídia. Citando Castell, os autores do estudo reforçam que os estudantes trazem para as salas de aula seus aparelhos eletrônicos e digitais equipados com sistemas wireless. É preciso que essas questões possam ser refletidas tanto em nível pedagógico, quanto em nível sociológico. Consequências no ensino, na aprendizagem e nas relações sociais são percebidas com o uso de aparelhos digitais na sala de aula.

Nossas reflexões convergem com Silva, Souza e Carmo (2016). Entendemos e afirmamos que ao trazer para o espaço da sala de aula seus aparelhos munidos de internet, os estudantes, que são nativos digitais, concebem outros processos de aprendizagem e de sociabilidades. Desse modo, é preciso que o professor conceba outros processos de ensinagem que tenham nas TDIC um caminho de diálogo, construção de conhecimento e de relações sociais mais críticas. Nesse posicionamento, dizemos que o aparelhamento digital é essa forma de ser e de estar que se manifesta através dos diversos usos que se faz dos aparelhos digitais, das redes sociais e das TIC. Inegavelmente, reiteremos o poder que a tecnologia tem na vida das pessoas.

Silva, Souza e Carmo (2016) afirmam que os recursos tecnológicos mais utilizados pelos docentes são o datashow e a televisão. Tais aparelhos são de uso consolidado no ambiente escolar. O computador é usado por uma parte dos docentes, mesmo que se considere que este equipamento é importante para uso nos ambientes virtuais, para atividades de comunicação pessoal e para o lazer. Um dos motivos que 
justificam o não uso do computador é justamente a não disponibilidade por parte da escola. Citando Kenski, os autores dizem que a escola conectada deve ser um ambiente tecnológicos em redes com uma infraestrutura adequada.

Algo interessante evidenciado no estudo de Silva, Souza e Carmo (2016) é que o grupo de docentes considera que, para utilização dos recursos tecnológicos, é preciso conhecimento sobre a complexidade do desafio que estava posto, demandando habilidades para utilizar as tecnologias como mediadoras no processo de ensino e aprendizagem. Ao citar Tardif, os autores demonstraram que as novas tecnologias são criadoras das práticas sociais de interação. Contudo, os autores colocam que, no caso dos cursos de formação da EJA, não quer dizer que os docentes irão reinventar suas práticas e seu fazer pedagógico e incorporar recursos tecnológicos na sala de aula. Para isso, os docentes apontaram a necessidade de uma formação profissional inicial que conscientize e forme o profissional para uso das TIC.

Por outro lado, a escola deve oferecer a infraestrutura para o bom uso das TDIC na mediação da aprendizagem, mas deve também fazer manutenção dos equipamentos e aparelhos usados. Vemos, como Silva, Souza e Carmo (2016) mostram, que, há um paradigma educacional que se coloca em evidência: a profissionalização docente diante das TDIC.

Prosseguimos e encontramos o artigo Novas tecnologias, a busca e o uso da informação no ensino médio, de Anderson Messias Roriso do Nascimento e Kelley Cristine Gonçalves Dias Gasque. Esse artigo, fruto de uma pesquisa de doutorado, foi publicado no ano de 2017 na revista Informação \& Sociedade: Estudos, da Universidade Federal da Paraíba. O problema de pesquisa foi: como ocorrem a busca e o uso de informações por jovens do ensino médio para a formação escolar no contexto das novas tecnologias?

O trabalho se desdobra sobre como os jovens no ensino médio buscam e usam a informação por meio das novas tecnologias para a formação escolar. A metodologia adotada foi o método documentário fundamentada na análise de grupos de discussão. A construção teórica abrange a discussão sobre o conceito de novas tecnologias, juventude, ensino médio, busca e uso da informação e letramento informacional.

Os autores trazem algumas questões de grande destaque nos achados da pesquisa. Sobre a importância da internet, da escola atual, do ensino médio e do uso de recursos tecnológicos para a pesquisa escolar, os grupos de discussão trazem 
questões pertinentes sobre a juventude na contemporaneidade e como ela é massivamente marcada pelas TIC.

Para os estudantes participantes da pesquisa, a internet possibilita ampliar as informações obtidas na escola. A internet serve para fins de entretenimento e para fins de estudos. Contudo, nos mostram Nascimento e Gasque (2017), a visão estudantil sobre os problemas gerados pela internet é reduzida a termos econômicos. Para os autores, os jovens da sociedade contemporânea são chamados de "geração zapping" (NASCIMENTO; GASQUE, 2017, p. 210). São jovens que mudando de canal o tempo todo, ou seja, a identificação é sempre fluida. Outro ponto de destaque é que o uso de recursos e aplicativos da internet requer concentração. Isso resulta também em concentração nos estudos.

Nascimento e Gasque (2017) trazem uma consequência negativa de se viver online constantemente: diminui-se o tempo de descanso e de sono e, assim, compromete-se a aprendizagem. Citando Turkle, os autores mostram que o uso desenfreado e constante das redes sociais e dos aparelhos digitais pode ser um sinal de preenchimento da ausência dos pais, o que leva os jovens a descobrir sua identidade no ciberespaço.

Ainda: o protagonismo dos jovens no ato de estudar é uma nova demanda da formação no ensino médio. Trazendo o pensamento de Demo, Nascimento e Gasque (2017) enfatizam a relevância do professor exercitar em sala de aula a prática da pesquisa. Isso torna a escola um lugar privilegiado na produção do conhecimento. A escola atual e os recursos tecnológicos, continuam os autores, contribuem significativamente para novos processos de ensino e aprendizagem. E os estudantes reconhecem que as instituições de ensino estão atentas às tais mudanças e se adaptando. Assim, comungamos da afirmação de Kensky trazida por Nascimento e Gasque (2017) ao dizer que novas estruturas educacionais são demandadas pelo constante fluxo de interações nas redes.

Outro ponto de destaque trazido pelos autores do estudo é que, apesar de os jovens utilizarem cotidianamente aparelhos digitais e novas tecnologias, nem sempre o fazem da melhor maneira, visto que uma boa quantidade, apresentada no estudo, não consegue identificar uma maneira confiável para as necessidades escolares. Assim, é papel do professor demonstrar o valor educativo das TDIC na sala de aula, bem como as instituições de educação devem proporcionar altos níveis de 
investimento para se chegar a uma mudança real na educação por meio do uso das TDIC.

Sobre a busca de informação entre jovens no contexto escolar, os estudantes preocupam-se em encontrar informações de forma mais rápida, sem se preocupar com a origem da informação. O Google, Wikipédia e Youtube foram as plataformas mais consultas pelos estudantes. O site Escola Brasil também aparece nas consultas. Nascimento e Gasque (2017) relatam que essa preocupação em encontrar uma informação mais rápida e sem se preocupar com a fonte, também é partilhada pelos professores, que buscam conteúdos em canais de informações mais próximos e rápidos, não se preocupando com a qualidade da informação.

Para Nascimento e Gasque (2017), os estudantes, em sua maior parte, usam o Youtube, Skype, WhatsApp e Facebook como principais redes sociais para estudo e socialização. Já em relação aos recursos tecnológicos, os mais utilizados foram Ipad, computador e celular. A biblioteca escolar é uma realidade distante, onde a rotina estudantil a exclui, justificando acervo limitado e desatualizado.

Acerca do estudo e das propostas de atividades de ensino e aprendizagem no ensino médio, Nascimento e Gasque (2017) analisam que os estudantes fazem revisão a partir do conteúdo ministrado em sala de aula e para isso consultam resumos no caderno e pesquisas na internet. Citando Bauman, Nascimento e Gasque (2017) alertam para a necessidade de cuidados voltados ao uso das tecnologias de um modo efetivo, pois as distrações podem se tornar armadilhas. Isso mostra, por exemplo, que os estudantes preferem, muitas vezes, a leitura de material impresso do que o digital, pois a leitura digital, diante das possibilidades de entretenimento, pode distrair o estudante.

Diante de tudo isso, os autores concluem o estudo apontando para a necessidade em se lidar com a multiplicidade e quantidade de informações produzidas na sociedade contemporânea. Por um lado, a realidade do ensino médio é centrada na competitividade dos exames de vestibular. $\mathrm{O}$ ensino e aprendizagem tem caráter de treinamento. Assim, a formação humana e a produção de conhecimento são preocupações distantes.

Nascimento e Gasque (2017) ainda mostram que o uso das novas tecnologias ocorre de modo pouco sistemático e sem funcionalidade objetiva. Os conteúdos não são integrados ao currículo. A dimensão do aprender a aprender é pouco engajada nos processos de aprendizagem. Muitos estudantes não são letrados 
informacionalmente. Assim, utilizam recursos simples de busca, mas o foco da busca é sempre a facilidade de acesso.

Os autores sinalizam para a formação de professores voltada para a aplicação dos conteúdos de letramento informacional. Além disso, há a necessidade de criar espaços de comunicação para formação da comunidade. E, para finalizar, Nascimento e Gasque (2017) evidenciam o ensino médio como etapa de formação humana, ética e cidadã que possa contribuir para a preparação dos sujeitos para a vida e que contribuem para a sociedade de maneira crítica e autônoma.

O último trabalho analisado foi o artigo de Valdeci Reis, Geovana Mendonça e Lunardi Mendes. Intitulado De iniciantes a vanguardistas: o uso de tecnologias digitais por jovens professores, o trabalho foi publicado em 2018 pela revista Holos e faz parte de um recorte de uma dissertação de mestrado em Educação. O artigo discute três perfis de professores: iniciantes, moderados e vanguardistas, compreendendo os usos que tais professores fazem das tecnologias digitais. O objetivo do artigo é compreender como jovens professores nascidos em uma sociedade em rede incorporam e usam as tecnologias digitais na sala de aula; a metodologia da pesquisa foi a abordagem etnográfica virtual.

Reis, Mendonça e Mendes (2018) mostram que é necessário compreender o papel da educação na contemporaneidade e isso significa empreender esforços que consigam avaliar esteticamente a era tecnológica que atravessamos. Ainda, analisam os autores, é preciso refletir com criticidade a sociedade que atravessamos, pois ela é fundada na conexão de redes digitais. Os autores, e aqui há uma estreita aproximação com nossa pesquisa, dizem que as redes digitais impactam nossa subjetividade.

Divergimos quando, seguindo os caminhos propostos por Lévy (2000), não falamos em impactos, mas em implicações. A ideia de que as redes digitais impactam a subjetividade nos faz voltar à etimologia da palavra impacto: que quer dizer impelido, contra (MICHAELIS, 2020). Ora, a ideia de impacto nos leva a acreditar que as redes digitais são grandes estruturas que entram em choque contra nós, que causam perturbação e outros sentidos negativos. Dizemos implicações porque acreditamos que as redes digitais, assim como os aparelhos digitais, se cruzam com nossos sentidos e produzem novos conhecimentos, sensações e percepções.

Os autores, ao citarem Guatarri, dizem que a complexidade da engenharia da informação, bem como os novos processos subjetivos produzidos através das redes 
digitais, contribui para analisar a sociedade atual. Importante que os autores do estudo também fazem uma denúncia: há um paradoxo disseminado pelo uso das redes: de um lado aqueles que detêm a riqueza, de outro lado aqueles que não têm as mínimas condições de subsistência. Assim, encontramos aqueles que produzem e detêm a informação, e aqueles que consomem.

Ponto interessante trazido por Reis, Mendonça e Mendes (2018, p. 313) é que os sistemas informáticos são, em sentido mais simples e objetivo, "formas hiperdesenvolvidas, hiperconectadas, hiperconcentradas da subjetividade humana". Não ousamos tanto quanto os autores, mas seguimos este caminho para afirmar que as subjetividades são expressas na realidade virtual, de modo conectado e sutil. Assim, não há como desviar-se da tecnologia. Cabe-nos entender as relações de poder que são estabelecidas nas conexões digitais.

Os autores são enfáticos ao afirmarem que os artefatos tecnológicos, juntos da mobilidade da comunicação, produzem novos processos de subjetivação. Concordamos com Reis, Mendonça e Mendes (2018) e prosseguimos: os artefatos tecnológicos produzem também novas sociabilidades, novas cosmologias, outros conhecimentos de mundo. Assim, os autores trazem a necessidade de se (re)pensar a aprendizagem com a utilização das redes sociais.

O papel do professor é redimensionado diante destes fatos. Reis, Mendonça e Mendes (2018) mostram que os jovens professores têm maior tendência em usar artefatos tecnológicos na sala de aula. Não se deve somente ao fato de que eles nasceram em uma sociedade de ampla difusão de redes e artefatos tecnológicos digitais. Contudo, esse fato se deve às práticas desses professores e sua aproximação com a temática, seja por meio de cursos extracurricular, seja mesmo na formação continuada ou na pós-graduação. Assim, concluem os autores, é imprescindível que existam discussões sobre a relação currículo, formação de professores e tecnologias digitais.

Assim, após analisar estes trabalhos, percebemos a necessidade ainda maior de discutir sobre o aparelhamento digital no ensino de sociologia. Acreditamos que os estudos abrem caminho para nossa discussão e muito contribuíram para que pudéssemos pensar nosso objeto de pesquisa. Propomos, portanto, investigar o aparelhamento digital no ensino de sociologia para percebermos quais são as implicações para a formação humana nesta etapa de ensino. 


\section{REVISÃO BIBLIOGRÁFICA: A PÓS-MODERNIDADE, O SUJEITO E AS INTERFACES DIGITAIS}

\subsection{Relações sociais, modernidade e liquidez}

As relações sociais são um fenômeno dinâmico de grande discussão para o campo sociológico. Interessante caminhar na perspectiva de Castro (2002, p. 122) quando nos aponta para as relações sociais não como uma "província ontológica distinta", mas como possibilidade dos fenômenos sociais enquanto relações como sociais. Isso quer desmitificar, epistemológica e metodologicamente, as relações sociais como algo distante dos indivíduos, como uma estrutura sólida e imutável, estabelecida a priori e independente da ação dos sujeitos.

Avançamos e ainda afirmarmos que para se pensar as relações sociais é necessário radicalizar o conceito de social, que consiga admitir todas as relações como sociais porque dispõem de condições suficientes para sinalizar as produções simbólicas e de poder contextualizadas a determinado recorte temporal e histórico.

Dito isto, consideramos a discussão sobre relações sociais a partir da perspectiva de Zygmunt Bauman. Nossa opção teórica se deve ao fato de que este sociólogo polonês possui uma vasta produção teórica sobre o tema e mais, ele

discorre sobre as relações sociais na modernidade, o que, no nosso estudo, é essencial para compreendermos o nosso objeto de pesquisa.

As teorizações de Bauman nos mostram uma crítica sociológica acerca do tempo e de sua velocidade. Para ele, a modernidade transformou-se em um espaço único, diferente de outros períodos históricos da humanidade, onde podemos encontrar duas fases diferentes: a fase sólida e a fase líquida.

Para Bauman (2001), a modernidade é semelhante a uma metamorfose, se levarmos em consideração as transformações que ela passou. Essas transformações são, sobretudo, no social, objeto de análise do sociólogo. Nesse sentido, podemos afirmar que a sociedade que entra no século XXI não é mais moderna que aquela que entrou no século XX: elas são modernas de jeitos diferentes.

A característica da modernidade é a forma como as relações sociais acontecem. Assim, o autor nos diz sobre a marca dessas relações: "compulsiva e 
obsessiva, contínua, irrefreável e sempre incompleta modernização" (BAUMAN, 2001, p. 40).

Ao interpretar a modernidade, com o objetivo de demonstrar a sociedade e as relações sociais que são tecidas neste recorte temporal, do mesmo que Bauman (2001), o sociólogo judeu Walter Benjamim (1987) expõe as experiências da modernidade como um conhecimento fragmentado. Ele chama de experiências não autênticas ou inautênticas. A modernidade passa a barganhar a experiência autêntica pela experiência não autêntica. As sociedades modernas emergem como sinal do declínio das experiências e este declínio é resultado do capital e patrimônio culturais que condensaram variadas características e perderam sua capacidade genuína de assimilação.

A vida social moderna foi forjada em uma dinâmica tal, que isolou o sujeito do bojo cultural, promovendo o distanciamento desse sujeito das experiências autênticas. O que dizemos com isso? Ora, assim como Benjamin (1987), acreditamos que a experiência é fonte das criações e da superação do indivíduo por ele mesmo. Pelas experiências autênticas, ele é levado a comunicar novas e outras coisas do mundo. $A$ decadência da experiência, ao contrário, conduz o sujeito à sua ruína. Assim, podemos entender que as esperanças na modernidade são frutos de um declínio cultural:

\begin{abstract}
Esses quadros são talvez a cópia da Renascença terrível e caótica na qual tantos depositaram suas esperanças. Aqui se revela, com toda clareza, que nossa pobreza de experiência é apenas uma parte da grande pobreza que recebeu novamente um rosto, nítido e preciso como o do mendigo medieval. Pois, o valor de todo o nosso patrimônio cultural, se a experiência não mais o vincula a nós? A horrível mixórdia de estilos e concepções do mundo do século passado mostrou-nos com tanta clareza aonde esses valores culturais podem nos conduzir, quando a experiência nos é subtraída, hipócrita ou sorrateiramente, que é hoje em dia uma prova de honradez confessar nossa pobreza. Sim, é preferível confessar que essa pobreza de experiência não é mais privada, mas de toda a humanidade. Surge assim uma nova barbárie (BENJAMIN, 1987, p. 115).
\end{abstract}

A experiência autêntica foi ofuscada pelas transformações sociais que a modernidade acabou por produzir como condição deste tempo, a saber: crescente urbanização, o capitalismo, a sofisticação da técnica e a indústria cultural. Essas condições inerentes à modernidade colocaram o sujeito afastado das experiências autênticas e, pois, o deslocaram, o homem e a mulher para novas periferias existenciais humanas. 
Esse sujeito é tomado como herói por Calegari (2016, p. 102): "[...] as experiências do homem moderno são comparadas às de um herói, pois são necessárias forças superiores para suportar as pressões da vida moderna". Basta ver que os sujeitos são transportados para outros espaços, por meio do fenômeno da urbanização, além de eles manterem outra relação com o trabalho e a cultura, visto que o capitalismo e o desenvolvimento da técnica sedimentam novos processos sociais.

Ora, é mister pensarmos que essas pressões da vida moderna, denunciadas por Calegari (2016), convergem com as ideias de Benjamin (1987) e do próprio Bauman (2001), uma vez que as teorizações trazidas por esses autores convergem para a ideia da Modernidade Líquida. Nos diz Bauman (2001) que, logo no começo da era moderna, as estruturas sociais eram sólidas. Família, religião, educação e política, por exemplo, constituíam-se como estruturas que, em seus sistemas de formação, influenciavam desde os sistemas de mercado até a construção das subjetividades e tinham por base as tradições, os costumes e as intencionalidades dessas instituições e estruturas.

Afirma Bauman (2001, p. 147): "O tempo rotinizado prendia o trabalho ao solo, enquanto a massa de prédios da fábrica, o peso do maquinário e o trabalho permanentemente atado acorrentavam o capital. Nem o capital, nem o trabalho estavam ansiosos para mudar, e nem seriam capazes disto". Podemos pensar que o tecido social era mantido pelas relações intersubjetivas. Esse tecido dependia de padrões e regras que eram estabelecidos pelas instituições sociais. É neste sentido que o nascimento da modernidade pode ser considerado um período de solidez, ou seja, poucas transformações na sociedade.

Bauman (2007, p. 65) afirma:

[...] o modelo mais importante dessa foi a solidariedade interna da fábrica, sindical e ocupacional, que fincou raízes e floresceu "naturalmente" no ambiente relativamente estável, da 'fábrica' fordista, o epítome do ambiente sólido-moderno em que os 'carentes de outro capital' se fixavam.

Em Durkheim (2007), encontramos uma descrição breve e profunda sobre as sociedades pré-capitalistas. Nelas, a relação de parentesco era o elemento determinante para a identificação social. É justamente esse fenômeno que define a solidariedade mecânica, ideia desse sociólogo. Assim, em um período pré-moderno, 
as relações sociais eram ligadas às estruturas das instituições sociais, sendo elas fundamentais para a funcionalidade dos costumes, das tradições e da construção da identidade do sujeito.

Em contrapartida, Bauman (2009) nos mostra na sua obra Vida Líquida, que o tipo de vida que foi desenvolvido no final do século XX e início do XXI foi um modo de vida constituinte da sociedade moderna líquida. Para ele, em uma sociedade com esse modo de vida, os indivíduos não destinam tanto tempo para consolidar as tradições, os hábitos culturais e as formas de ação.

A modernidade, que é descrita de diferentes formas, pode ser considerada como tendo uma fase sólida e outra líquida. Enquanto a modernidade sólida é uma oposição à modernidade líquida. Esta carrega traços iluministas que se transformaram em teorias positivistas, especialmente pelo poder cultural da Revolução Industrial e que culmina com o fordismo. A sociedade moderna é assente em uma racionalidade que tem como base a ciência e a técnica, bem como com o planejamento, elemento estruturante desta sociedade.

Desse modo, a modernidade líquida ganha características de inconstância, leveza, fluxo contínuo de relacionamentos. O movimento é a ordem das relações sociais, bem como a mutação. Esses elementos, associados à falta de segurança, criam uma estrutura de sentimentos que fundamentam a falta de garantias de proteção e a falta de credibilidade no outro. Há uma crescente aposta na liberdade como condição do individualismo e que promove a busca desenfreada e contínua por novas relações a cada instante.

A velocidade é o principal elemento da modernidade; o tempo não faz mais sentido; as realidades são ampliadas; o sujeito é preso em uma metamorfose infinita, buscando novas configurações a todo instante: "[...] em suma, a sociedade de consumo líquido-moderna despreza os ideais de 'longo prazo' e da 'totalidade'[...]” (BAUMAN, 2009, p. 64).

A modernidade é então, uma passagem das transformações sociais, econômicas e científicas. Sua intenção maior é superar os elementos estruturantes da Idade Média e 'salvar' a sociedade da velha incapacidade moral que impedia o desenvolvimento da razão como fonte de conhecimento de mundo e das produções e criações sociais. Os elementos sólidos construídos na modernidade sólida acabaram se 'derretendo' diante da dinâmica de fluxo contínuo e da mutação das relações sociais, de modo que: 
Se o "espírito" era "moderno", ele o era na medida em que estava determinado que a realidade deveria ser emancipada da 'mão morta' de sua própria história - e isso só poderia ser feito derretendo os sólidos (isto é, por definição, dissolvendo o que quer que persistisse no tempo e fosse infenso à sua passagem ou imune a seu fluxo) (BAUMAN, 2001, p. 9).

As relações sociais eram mantidas por regras e padrões que foram convencionados e estabelecidos pela religião, pela política e pela família. Durkheim (2007) aponta que essa regulamentação permitia a formação de uma consciência coletiva que mantinha uma coesão interna entre os indivíduos e suas relações com o social. A construção da modernidade enfrentou e superou marcas medievais. Podemos dizer que valores foram liquefeitos.

Essa liquefação dos elementos sólidos que formatavam as relações sociais é um projeto intencional da modernidade líquida, que possibilitou a busca desenfreada e descomprometida pelas liberdades, pela autonomia irrestrita dos sujeitos e pela autorregulação de valores. Assim, é possível compreender esta lógica quando Bauman (2001, p. 10) nos diz:

\begin{abstract}
Os primeiros sólidos a derreter e os primeiros sagrados a profanar eram as lealdades tradicionais, os direitos costumeiros e as obrigações que atavam pés e mãos, impediam os movimentos e restringiam as iniciativas. Para poder construir seriamente uma nova ordem (verdadeiramente sólida!) era necessário primeiro livrar-se do entulho com que a velha ordem sobrecarregava os construtores.
\end{abstract}

A modernidade líquida inverteu valores sociais. A individualidade passou a ser fonte das relações e fator preponderante para a multiculturalidade. O capitalismo passou a reger e construir outros tempos e espaços através da globalização, derrubando fronteiras e desarticulando instituições. Espaços públicos foram privatizados e espaços privados tornaram-se públicos. A globalização trouxe alguns aspectos negativos para as relações sociais na modernidade, como nos diz Bauman (2007, p. 30):

O novo individualismo, o emagrecimento dos vínculos humanos e o definhamento da solidariedade estão gravados num dos lados da moeda cuja outra face mostra os contornos nebulosos da "globalização negativa". Em sua forma atual, puramente negativa, a globalização é um processo parasitário predatório que se alimenta de energia sugada dos corpos dos Estados-nação e dos seus sujeitos (2007 p. 30).

Para o sociólogo, a globalização, em seus aspectos negativos, traz aspectos desconstrutivos e provocativos da interação humana de forma sólida. Não quer dizer que Bauman (2007) se coloque contra os processos de desenvolvimento trazidos pela 
globalização, mas que ele tem uma leitura crítica sobre as mazelas advindas da globalização. Assim, na modernidade líquida, a globalização representa um fenômeno recente e que merece ser discutido, bem como suas consequências para as relações sociais.

1.2 O sujeito da modernidade líquida e as sociabilidades modernas

Quando falamos da modernidade líquida, o fazemos para nos referirmos ao estado cultural e social da sociedade atual. Para Bauman (2001), a vida pública e privada, os relacionamentos humanos e as estruturas que forjam os processos de subjetivação na modernidade passaram por transformações que ressignificaram as tessituras sociais. As instituições sociais então, tornaram-se líquidas. Assim como os líquidos, a metáfora sinaliza para a disformidade institucional, que vai ganhando contornos outros.

Na modernidade líquida institui um outro tempo experimentado pelos sujeitos modernos: é o tempo da provisoriedade, da objetificação, do imediatismo, da supervalorização egóica. Se há liberdade, ela vem acompanhada da insegurança, que gera o medo da profundidade das relações dos sujeitos entre si e com o mundo (BAUMAN, 1998; 2001).

É nesse tempo que é líquido que a busca pela liberdade é acompanhada da sensação de impotência. O anonimato, a massificação e homogeneização das diferenças colocam o sujeito por sua própria conta na vida social. O que então, torna o sujeito responsável socialmente se as instituições sociais perderam sua solidez? Ora, são justamente as forças individuais que irão reger o sentir, o agir e o pensar dos sujeitos.

As contradições sociais são vistas através do paradigma - poderíamos dizer assim - da biografia dos sujeitos. Ou seja, é o sujeito e suas experiências em busca da liberdade que irão modelar as formas de estar no mundo social, sem a necessidade de recorrer às agências e instituições que possam oferecer segurança para os conflitos.

Fato é, conforme Bauman (2001) nos coloca, que as pessoas se tornam solitárias, ensimesmadas. Fecham-se nas suas experiências e nos seus medos. A disponibilidade para estar com o outro, quem seja ele, é limitada ou mesmo ausente. 
As relações tornam-se frágeis e mercantilizadas, sendo rompidas a qualquer momento quando ferem os interesses pessoais de uma das partes. Assim, "o interesse público é reduzido à curiosidade sobre as vidas privadas de figuras públicas e a arte pública é reduzida à exposição pública das questões privadas e a confissões de sentimentos privados (BAUMAN, 2001, p. 46).

Nisso, a compreensão da realidade é posta através da socialização e sociabilidade (BAUMAN, 1997). A socialização, para o autor polonês, é um conceito que se liga à interação com a estrutura social. Ela pretende criar um ambiente onde possibilite escolhas que podem ser discursivamente realizadas. Entra nesse mérito a lógica da racionalidade sobre o que se ganha e o que se perde com determinada escolha. Faz parte da socialização a crença em um futuro que é mediado pela ordem. As ideias dos fortes, nesse ponto de vista, são tomadas enquanto ideias fortes que devem modular a história, colocando de lado todos que se levantem contra a ordem.

A liberdade passa a ser restringida, bem como as escolhas. Se há um propósito a ser seguindo e estabelecido pela ordem, todos devem, em comum e coletivamente, seguir tal objetivo. Demanda, portanto, do sujeito a racionalidade, impondo o distanciamento de tudo que possa ser espontâneo. Como consequência, a sociabilidade vem enquanto uma ausência de quadro referencial e que acaba impossibilitando as previsões das ações dos sujeitos.

Para Bauman (1997), a sociabilidade provoca a unicidade, indo além do que é meramente racional. Ela é, geralmente, avessa às normalidades, às regras, à regularidade. É ela que cancela o sentido puramente mecânico da ação. Na modernidade líquida, a sociabilidade passa a ser uma marca profunda e elementar onde os sujeitos experimentam a não-referência. Ou seja, longe de esquemas cognitivos, éticos, morais e estéticos, longe de quadros referenciais, o sujeito se vê sozinho, consigo mesmo, pautando sua ação na individualidade que ele mesmo forjou.

A multidão surge como um grupo de indivíduos que partilham e compartilham ações imediatas, instantâneas, permitidas por ações e condições semelhantes. Riesman (1971) coloca a multidão como conjunto agregado pela solidão, que tem padrões comportamentais que rompem com a interação coletiva. Já nos anos de 1960, o autor percebe a emergência do sujeito dirigido, governado, guiado e orientado por si mesmo.

Esse fenômeno de ensimesmar o sujeito e ser guiado por suas próprias estruturas egóicas é o mesmo que atravessa as relações sociais na modernidade 
líquida. Essa teoria social nos indica que o processo, metafórico, de passagem de estado sólido para o líquido, não é um processo desprovido de relações de poder. Ao contrário, há uma concentração de poder no sujeito, quase que confundível com autossuficiência. Essa questão é originada justamente na busca plena pela liberdade e nas consequências dessa grande aventura moderna. Da mesma maneira,

[...] nenhum molde foi quebrado sem que fosse substituído por outro; as pessoas foram libertadas de suas velhas gaiolas apenas para ser admoestadas e censuradas caso não conseguissem se realocar, através de seus próprios esforços dedicados, contínuos e verdadeiramente infindáveis, nos nichos pré-fabricados da nova ordem (BAUMAN, 2001, p. 13).

A sociedade do risco é a imagem mais potente para imaginarmos a modernidade líquida e suas relações frágeis (BECK, 1997). Para o autor, os riscos são produções sociais e existenciais. Na bolsa existencial do sujeito se depositam os riscos e ele é condenado a lidar com eles. Justamente essa condenação que leva o sujeito a experimentar a política-vida (GIDDENS, 2002). Essa trata da realização do eu, considera a relação dialética entre o local e o global, bem como se volta para os sistemas e categorias próprios da modernidade. Algumas qualidades da modernidade líquida, como rapidez, radicalização, profusa intensidade e descontinuidade são valores que levam o sujeito a cair na política-vida (GIDDENS, 1991).

Mesmo com distintas visões sobre a modernidade, em Giddens (2002; 1991) e Bauman (2001) vamos encontrar o primeiro autor sugerindo que a modernidade geraria laços mais favoráveis que contribuiriam para uma vida social melhor. É na política-vida que as questões sociais poderiam melhor ser analisadas. Ainda para o autor, a busca pela liberdade na modernidade configura uma política emancipatória que poderia romper com os grilhões que limitam os sujeitos. É um movimento de lançar-se contra a exploração e opressões que vêm das instituições e mesmo de grupos de pessoas. Isso permitiria uma expansão do que Fridman (2014) veio a denotar como expansão da política de vida.

A isso, Giddens (2002) vai relacionar as questões de inconformidade e contestação que são emergentes dos processos de reflexividade do eu às políticas de autorrealização. Importa, nesse sentido, o tensionamento entre aquilo que é local e aquilo que é global. A política-vida corresponderia, em certa medida, à autonomia de ação, em que o sujeito escolhe, agenciado por si mesmo; "ela é uma política de escolha [...], que num nível individual e coletivo, alterou radicalmente os parâmetros existenciais da atividade social" (GIDDENS, 2002, p. 197). 
A política-vida vem a ser uma virada política sobre o próprio estilo de vida do sujeito social. O sujeito se indaga em que ética deve-se viver (GIDDENS, 2002). Isso o leva a outra descoberta e inquietação: quem ele pretende ser? Assim,

O surgimento da política-vida, afirmei, resulta da centralidade do projeto reflexivo do eu na modernidade tardia (...). A capacidade de adotar estilos de vida livremente escolhidos, benefício fundamental gerado por uma ordem pós-tradicional, está em tensão não só com os obstáculos à emancipação, mas também como uma variedade de dilemas morais (GIDDENS, 2002, p. 212).

Esse conceito tem intensa aproximação com a estética da existência de Foucault (1999), o que não apaga a crítica de Giddens (2002) a Foucault (1999). Para o autor, as investigações foucaultianas sobre as sociedades de controle não permitem visualizar a emergência e surgimento de sujeitos que promovem a subversão do poder. De modo mais incisivo, a crítica do sociólogo aponta para a relação entre corpo e agência. Mas, conseguimos realizar uma leitura foucaultiana sobre a estética da existência enquanto uma possibilidade da política-vida, uma vez que o sujeito, ao interrogar-se, produz uma estética existencial e novos modos e estilos de vida. Podemos mesmo dizer que as resistências são criadas, operadas e movimentadas como modos de subjetivação, que buscam romper com a autoridade instituída.

O sujeito na modernidade não tem escolha senão decidir e agir. Escapar dos processos de individualização e sair do jogo moderno líquido é uma demanda existencial que ainda não vislumbra uma saída, mesmo com todas as resistências criadas. A construção do eu é parte de um processo social reflexivo, inacabado, constante; as subjetividades deixam de ser pré-dadas e passamos a ser laboratório de nós mesmos (GIDDENS, 2002).

Bauman (2001) quando investigou o espírito da modernidade - sem cairmos nas armadilhas dos essencialismo, dizemos espírito, mas compreendo as diversas formas de modernidade - conseguiu perceber a vida contemporânea profundamente e efusivamente longe de laços sólidos e, principalmente, duradouros. As sociabilidades passam a ser forjadas em um cotidiano baseado na perspectiva e no desejo do eterno novo. Não há tempo para aprofundar os vínculos sociais e afetivos, tão liquefeitos e frágeis.

Para nosso contexto de contemporaneidade, o mal-estar é a própria inexistência da segurança, antes ofertada pelas instituições sociais. Bauman (2000, p. 24) alerta que o "mundo contemporâneo é um recipiente cheio até a borda de medo 
e frustação à solta que buscam desesperadamente válvulas de escape". É nesse mundo que Fridman (1999) consegue ver que houve mudanças de lugar entre o que se ganha e o que se perde com a segurança e seu desejo de constância e regularidade.

As sociabilidades na modernidade líquida pensam sujeitos que estão prontos, constantemente a se transformar. Como em um serviço onde consome conforme suas demandas e necessidades, o sujeito também vai sendo transformado e vai abandonando práticas e tradições na medida em que surgem outras demandas e necessidades para construir seu estilo de vida, que é liquefeito. É a eterna subordinação de construir suas subjetividades (BAUMAN, 1998). As experiências passam a ser colecionadas, visando aquilo que ainda não pode ser experimentado.

A liquidez das sociabilidades é organizada com vistas às aventuras, às insatisfações, ao imediato. Não há tempo para materializar hábitos, ações. O que importa é a busca por experiências ainda não sentidas. Mas qual experiência importa? Qual é capaz de agenciar o sujeito em seu seio social? Ora, a experiência mais desejada é sempre aquela que está por vir. Os processos de subjetivação padecem de um esquema temporal. As identidades são forjadas no esquecimento. Nos diz Bauman (1998, p. 36-37): "[...] a própria memória é como uma fita de vídeo, sempre pronta a ser apagada a fim de receber novas imagens". No esquecimento a construção das identidades, na modernidade, é um ato quase impossível.

3.3 Pensando a Cibercultura e outros cenários de aprendizagem a partir da Revolução Digital

Ao pensarmos na globalização, não podemos deixar de lado os aspectos digitais que impulsionaram outros processos de produção de subjetividades e de relações sociais. É o caso, por exemplo, da virtualização. Para Lévy (2011), a virtualização e suas marcas na modernidade têm afetado a informação, a comunicação, a economia e até mesmo os processos de exercício da inteligência. Mesmo que o virtual esteja associado ao não estar presente, Lévy (2011) nos mostra que a palavra se relaciona com a existência em potência e não em ato. Esse campo do virtual foi enunciado pelo digital. 
É no campo digital que as relações sociais sofrem contundentes transformações. Não somente as relações sociais, mas a própria construção dos sujeitos e do saber na modernidade. Nesse campo, podemos pensar outra arqueologia do saber: sujeitos que interagem em fluxo contínuo de trocas simbólicas, que produzem dados e informações diversas, que assumem posições autorregulatórias sobre suas interpretações de mundo e que constroem novos espaços e tempos não lineares. O território digital nos permite compreender melhor a ideia de inteligência coletiva.

Para Lévy (2011), a inteligência coletiva pode e é distribuída entre os indivíduos, não existindo um grupo privilegiado. O saber, assim, é algo própria e inerente à humanidade e, portanto, todos os indivíduos podem oferecer conhecimento. Ninguém há neste contexto que seja excluído da produção do conhecimento, de tal modo que a inteligência coletiva é um valor fundamental da modernidade.

Assim, o saber de um indivíduo é valioso para que determinados grupos possam se desenvolver. Nisso, podemos pensar que os intelectuais coletivos, ou seja, todos aqueles que produzem um saber contextualizado e necessário para um grupo, são mediados pelas tecnologias digitais da informação e comunicação. As tecnologias e os saberes dos indivíduos entram em profunda sinergia. Lévy (2000) afirma assim, que a coordenação dos saberes pode ocorrer no ciberespaço. Este vai além das tecnologias e instrumentos que fornecem uma infraestrutura mínima de tempo e espaço, mas diz respeito, sobretudo, ao tempo e espaço que convergem para o acolhimento dos saberes e indivíduos que produzem esses saberes.

O ciberespaço permite que indivíduos possam se interligar, independente do espaço geográfico onde se situem. É uma desterritorialização de saberes e o suporte para o desenvolvimento da inteligência coletiva. Ocorre assim, que os sujeitos são estimulados a desenvolverem e mobilizarem competências efetivas e múltiplas. Lévy (2011) nos mostra que a inteligência coletiva é uma proposta para além da cognição, mas se trata, prioritariamente, de um projeto global que supõe ações práticas que mobilizem sujeitos para a construção de competências. Ainda mais: é o reconhecimento e enriquecimento mútuo dos sujeitos que produzem saberes.

Interessante percebermos que quando Lévy apresenta a ideia de inteligência coletiva, o mundo estava superando a dicotomia ideológica entre os países socialistas ou capitalistas. Assim, vencida esta dicotomia, as identidades dos indivíduos foram abaladas e ruídas. O sociólogo tunisiano insistiu e persistiu para que outros caminhos 
fossem compreendidos para além das identidades étnicas, nacionais ou religiosas. Ele propôs então, a construção do laço social baseado no saber. Lévy (2011, p. 32) afirma que "o núcleo da engenharia do laço social é a economia das qualidades humanas".

De outro modo, o que reúne os indivíduos não é mais o lugar geográfico ou uma ideologia, mas as capacidades de partilhar os saberes individuais. Isso porque as identidades passariam a ser identidades do saber. Esse saber não diz respeito aquele científico, mas aquele que é extensivo à vida, que se relaciona com o saber viver e viver saber (LÉVY, 2011).

A inteligência coletiva pretende tornar o saber em uma base principal para as relações humanas. Porém, para Lévy (2011), isto só será possível quando construirmos o espaço do saber. Neste espaço, as relações humanas valorizam os sujeitos e suas habilidades; é um espaço virtual. Para o sociólogo, o espaço do saber está em construção na modernidade e ainda não é efetivo e pleno. Mesmo que as tecnologias disponíveis permitam colocar os sujeitos em processos sinérgicos que efetivam até certo ponto o espaço do saber, esse espaço requer mudanças políticas, sociais e educacionais.

O espaço do saber é elemento que define a produção coletiva do conhecimento, bem como a possibilidade do exercício de livre pensamento. Há ligações entre os espaços e o indivíduo coexiste simultaneamente nos espaços geográficos, virtuais, digitais e outros. Porém, na modernidade, as possibilidades advindas das tecnologias imprimem transformações e até mesmo mutações nos modos de vida das pessoas que são típicas do espaço do saber. Conforme Lévy (2011, p. 198):

\begin{abstract}
Dessa forma, cada novo espaço "repousa" sobre os precedentes. Nenhum espaço antropológico pode destruir os que estão "embaixo" dele sem arriscarse a se autossuprimir [...] As situações e os seres concretos encontram-se imersos em várias frequências antropológicas ao mesmo tempo [...] Os espaços antropológicos mantêm relação, mas segundo uma causalidade sem contato. Por exemplo, tudo o que um intelectual coletivo perceber, ele o integrará a seu mundo, avaliará segundo seus critérios, submeterá a seu próprio tempo, metamorfoseará apropriando-se dele, de tal modo que não restará, na entidade considerada, nenhuma ligação com o outro meio antropológico.
\end{abstract}

O teórico se mostra otimista em relação ao uso das tecnologias digitais da informação e comunicação. Ele fala, então, da cibercultura como um projeto utópico. As interações digitais e virtuais criam coletivos de inteligências em espaços que 
dispõem de liberdade para a comunicação. Assim, formatam a autonomia individual na medida em que as pessoas podem se expressar livremente, não passando por crivos alheios e de autoridades exteriores a si mesmo.

Esse pensamento é crucial para Lévy (2011). Isso porque leva a outras reflexões sobre o saber produzido no mundo virtual. Esse saber é produzido a partir de interações e contatos diretos entre participantes que se encontram livre de interferências. Essa interação e comunicação permitem o acesso de variadas informações que carregam experiências criativas da modernidade. A autonomia passa a ser o meio desse saber, inaugurando outras condições para o desenvolvimento do conhecimento.

A escola, nessa perspectiva, passa a ocupar uma posição oposta às tecnologias digitais da informação e comunicação: "É certo que a escola é uma instituição que há cinco mil anos se baseia no falar/ditar do mestre, na escrita manuscrita do aluno e, há quatro séculos, em um uso moderado da impressão" (LÉVY, 2011, p. 8).

A escola é o espaço onde os conhecimentos são impostos, mesmo que alguns enfrentamentos sejam realizados nesse sentido. Ela não oferece situações para que o saber seja construído a partir da autonomia do pensar e do sentir; não valorizam o saber individual. Mesmo assim, a modernidade nos coloca diante da cibercultura e acabamos por criar novas maneiras de nos relacionarmos com o social. Chamaremos, a partir das ideias de Lévy, de aparelhamento digital o modo como os indivíduos se mobilizam para, na escola, produzir saberes individuais.

Em favor do autodidatismo, o aparelhamento digital mobiliza o indivíduo por meio das tecnologias digitais da informação e comunicação para a produção de um espaço de cibercultura, onde afloram novas dinâmicas de conhecimento e que possibilita informações flexíveis, personificadas e aprendizados em rede. Para isso, há uma exploração livre dos meios pedagógicos que valorizam a subjetividade dos intelectuais coletivos. Ainda, o aparelhamento digital é a condição de aprendizagem da modernidade, pois não dissocia o uso das tecnologias digitais da informação e comunicação com a produção de saber individualizado.

No aparelhamento digital os indivíduos têm como suporte as tecnologias digitais da informação e comunicação para estabelecer as relações sociais; também neste fenômeno, o saber é produzido em virtude de aparelhos e mídias digitais que criam novos espaços e novos tempos de interação social e produção da subjetividade. 
Esses aparelhos e mídias digitais é uma extensão da própria pessoa que a utiliza. Assim, podemos dizer que os aparelhos e mídias digitais são condição sine qua non para produção de saberes individuais. Lévy (2011) afirma que a inteligência coletiva reconfigura as noções de conhecimento porque produzem capacidades criativas nucleares e novos modos de utilizar as TDIC em favor da aprendizagem. Neste sentido, é importante refletirmos sobre o lugar da educação nesse contexto.

\subsection{Cibercultura, ciberespaço e processos de subjetivação}

O ciberespaço (LÉVY, 2000) apresenta-se enquanto um oceano de informações onde as pessoas navegam e constroem uma realidade outra na modernidade. Ele tornou-se um espaço formativo e modelador dos costumes, comportamentos e hábitos, levando as pessoas a sentirem um outro mundo. Faz parte do ciberespaço, como dispositivo de formação humana e social, a construção da percepção de si e dos outros. É nele que as tecnologias digitais da informação e comunicação vão despontar como mediação social, cultural e político, bem como permitir engajamento no mundo.

Nesse sentido, Sperotto (2009) mostra-nos que o ciberespaço é constituinte de novas subjetividades. O uso e a operacionalização das TDIC para diversos fins acabam por construir um ambiente virtual que personaliza identidade, subjetividades e modos de aprender. Essa potência do ciberespaço decorre de várias ondas de transformações sociais e nos modos de produção

A internet e as TDIC são responsáveis por introduzir novos hábitos, novas visões de mundo, novos modos de estar no social. Ao tornar a vida mais dinâmica, as TDIC acabam transformando os processos de comunicação e de produção de cultura, de saber e de poder. Nesse sentido, Costa (2008) nos mostra que os sujeitos não estão mais satisfeitos em compartilhar o espaço físico, mas também demandam construir espaços virtuais e relações que são atravessadas pelo virtual.

Podemos falar, assim como assegura Castells (1999), de uma revolução tecnológica orientadas nas TDIC. A cultura passou a ser afetada pelos espaços virtuais e pela realidade tecnológica. Lévy (2000) defende que a cibercultura é esse espaço próprio das particularidades dessa revolução tecnológica. Localizada em um ciberespaço, a cibercultura emerge desse contexto, mas ela própria o modifica através de técnicas materiais e intelectuais. 
Para Lévy (2000), esse oceano composto de uma infraestrutura e de materiais comunicacionais, que é o ciberespaço, ao intercomunicar e interligar pessoas e o mundo, acaba por criar formas novas de ser. Interessante percebermos que não se trata de um agenciamento ou mesmo de uma estrutura. Falamos de um espaço enquanto campo (BOURDIEU, 1989), um espaço onde forças são disputadas em vistas a representar, legitimamente algum valor.

Interessa-nos questionar: quais forças sustentam o jogo do ciberespaço? Que tipo de sujeito é pensado neste campo? Quais relações materiais e sociais deste campo são dispostas e inclinadas a uma educação pautada na formação humana? Como pensar uma lógica de justiça social e tecnológica que considere a emergência do ciberespaço? Ora, Hall (2004) evidencia que entre a vida social e a técnica há uma estreita relação com as tecnologias digitais. Isso acaba por resultar em novas práticas culturais e novas sociabilidades.

No ciberespaço encontramos possibilidades de mobilização social, engajamento político e cultural, bem como formas outras de relações sociais. As demandas sociais tornam-se múltiplas porque são as possibilidades de pensar, sentir e agir neste campo, especialmente quando pensamos as redes sociais e seus usos. Falamos da interconexão como elemento e valor do ciberespaço. Esse elemento é gerador do que entendemos como novos modos de universalização. Em concordância com Lévy (2000), o que acaba caracterizando uma universalidade - ou se quisermos falar em outro termo, totalização - no ciberespaço é sua capacidade não totalizante, mas múltipla. Na universalidade do ciberespaço conseguimos interagir com os diversos quadros que compõem o universal.

Isso torna a cibercultura e o ciberespaço uma construção histórica sem antecedentes, pois, segundo Rüdiger (2004), há uma conexão dialética entre o humano e seus recursos tecnológicos. Essa conexão é responsável por transformar o mundo. Ao transformar o mundo, o modo de ser, individual e materialmente, também é transformado. Lemos (2003) discute essas transformações colocando que a cibercultura é uma forma social e cultural que surgiu entre as trocas sociais, humanas e tecnológicas.

A cibercultura passa a ser uma mobilizadora das necessidades do sujeito de se comunicar e de conhecer o mundo. As redes sociais atuariam nesse sentido, permitindo que essas necessidades sejam atendidas. Nos diz Recuero (2009) que as redes sociais, enquanto meios emergentes e modernos dos sujeitos se comunicarem, 
implicam em difusão de informações. A relação entre local e global é tensionada com vistas à circulação das informações de modo rápido e imediato. É assim que o autor ainda nos mostra que os sujeitos sociais são fortemente marcados por esse imediatismo da difusão das informações.

Nessa questão, seguimos os passos apontados por Lévy (2000), ao afirmar que ciberespaço é campo de prática para a movimentação social virtual. Pela interconectividade, os sujeitos movem-se conforme seus interesses, seus posicionamentos e passam a constituir as comunidades virtuais. Espaço e tempo são ressignificados, visando relações sociais pautadas nas trocas virtuais, nos ganhos sociais dessas trocas e no desejo de inclusão, já que a sociedade pós-moderna é pautada no agenciamento de si. A tecnologia vem como uma força histórica, humana e social que desvela as potencialidades criativas do sujeito, intensificando o convívio virtual.

$\mathrm{Na}$ cibercultura os indivíduos não apenas navegam no ciberespaço. Como afirma Virilio (1999, p. 21), a cibercultura amplia "a espessura ótica das aparências do mundo real". Essa lógica adentra a vida privada dos sujeitos que estão no ciberespaço. Como já foi mencionado, tempo e espaço são ressignificados no ciberespaço. O tempo passa a ser regimentado pelo imediatismo, a transmissão e difusão direta das informações. O espaço é acessado em múltiplos lugares. Há um alargamento da própria noção de espaço.

Pensamos, a partir de Foucault (1988), que novas forças surgiram no pósSegunda Guerra Mundial. Modos de controle surgem como demandas de uma sensação de segurança. Esses contornos geraram nossas condutas, que, em um movimento de inconclusão, requerem constantes atualizações. A noção de individualidade e de um sujeito enquanto corpo massificado atravessa também o ciberespaço. É assim que há a criação e reelaboração de subjetividades mais solitárias, voltadas para si mesmo.

As diferenças sociais, os processos de identificação, as singularidades são disputadas pela ideia de homogeneização, porque é mais fácil controlar as massas. O controle dá a sensação de segurança. Afirma Hardt (2000, p. 361):

Da mesma maneira, talvez, com que Foucault reconheceu no panóptico o diagrama do poder moderno e da sociedade disciplinar, o mercado mundial poderia fornecer uma arquitetura de diagrama (mesmo não sendo arquitetura) para o poder imperial e a sociedade de controle. 
A velocidade, como valor do ciberespaço, passa a reconfigurar as relações sociais, bem como as formas de poder e de saber. Há uma sincronia e proporcionalidade entre poder e saber e a própria velocidade. Quanto mais veloz, mais poder e mais saber. Essa sincronia do imediatismo no ciberespaço, acaba por fazer surgir um novo tempo: um tempo próprio do virtual, onde o movimento instantâneo regimenta e inaugura padrões de comportamento. Virilio (1999) mostra que há uma inércia nisso, que faz o sujeito ser deslocado na velocidade e mesmo assim ele permanece em um ponto zero. Isso reduz o mundo a um lugar sem distinção, automático, onde não temos tempo para pensar e sim para agir rapidamente ao que se chega enquanto informação.

Esse tempo, próprio do ciberespaço e cibercultura, converge na televigilância, onde tudo é vigiado e, continuamente, sem intervalos, é examinado. A luz das telas fazendo uma analogia às TDIC e às redes sociais - passam a acompanhar rigorosa e constantemente os gestos individuais e a construção do cotidiano. De tão cotidiana e tão banalizada, nossas ações sofrem o poder invisível e telecontrolado das TDIC. Castells (2000) diz que a sociedade atual poderia ser compreendida como aquela que acumula, armazena e processa informações imediatas. Não interessa tanto a produção e o armazenamento das riquezas materiais, mas da informação retroalimentadas e interconectadas.

A informação ganha um papel preponderante nos nossos processos de subjetivação. A partir da informação, o indivíduo transforma o conhecimento de mundo e de si e passa a agir de tal modo. É a base da sociedade do conhecimento, caracterizada por uma topografia da rede. Essa rede é mobilizada e formatada por sua flexibilidade e potencialidade de articulação e transmutação de si mesma, chegando a ser fluida, não estanque, inconstante.

Castells (2000) chega a falar de uma materialidade da virtualidade, que ganha um corpo informacional, difuso, dotado de tecnologias e microeletrônica. Desse modo, as ferramentas tecnológicas, além de fazer parte do próprio sujeito, vão dar forma aos arranjos sociais, chegando a construir uma máquina social carregada de virtualidade. Essa materialidade virtual, se assim podemos chamar, é específica da subjetivação no ciberespaço. O valor da rede surge nessa noção de formação de subjetividade. Ao invés de processos de subjetivação individual, fechado em si mesmo, passamos a experimentar um processo múltiplo e coletivo. 
As subjetividades são forjadas e pensadas em multiplicidade - para em seguida se homogeneizar -, rompendo com a noção de sujeito. Nisso, o sujeito ganha uma conotação de máquina (DELEUZE; GUATTARI, 2010), a síntese de heterogêneos. A máquina carrega o múltiplo e o unifica, perdendo a potência da criação em favor da automação, da técnica, do mecânico. Falamos, portanto, de subjetividades maquinadas, elaboradas no ciberespaço enquanto construção dos valores ontológicos e pragmáticos de tal campo.

Thompson (1998) mostra que as TDIC modificaram as formas de comunicação e, diretamente, nos modos que interagimos uns com os outros. A mobilidade permitida no ciberespaço é singular e provovou comportamentos e processos subjetivos outros. Para Lévy (2000), que traz uma concepção mais positiva acerca dessas relações no ciberespaço, o maior contato entre as pessoas intensificaria o convívio. Nos distanciamos desse pensamento, partindo das noções já apresentadas até aqui. Calvino (2009) mostra que vamos nos subjetivando de modo híbrido com as tecnologias. É aqui que pensamos de modo mais foucaultiano e deleuziano. Acreditamos que as máquinas se conectam com as máquinas; e se as subjetividades no ciberespaço são maquiandas, entramos em um processo de elaborar interfaces digitais em nossas relações sociais e nos processos de subjetiviação.

A aparência que tomamos de empréstimo às máquinas é de um sujeito informacinal, mecânico, totalmente móvel e imediato. As interfaces tecnológicas que modulam nossas subjetividades constituem uma interação de todos-com-todos. Estabelecemos uma rede de contratos fundados em interesses pessoais. Passamos a desterritorializar saberes, discursos e vozes. Isso fragmenta a noção de identificação. Evidente que é uma maneira negativa de se perceber as afetações dos processos de subjetivação no ciberespaço, contudo, isso é um dos reflexos considerados a partir da modernidade líquida.

Calvino (2009) reitera que a sociedade em telas dilui processos de subjetividades mais sólidas. Cria-se uma aparência de subjetividade mais ou menos verdadeira e/ou autêntica para esconder as reais demandas individuais e afetivas dos sujeitos sociais. Com suas telas e dispositivos conectados, os sujeitos produzem agenciamentos através das tecnologias.

Contudo, não podemos esquecer que essa crítica levantada não pode perder de vista que as subjetividades na modernidade são polifônicas e constituídas por 
condições e possibilidades de discursos múltiplos que espelham outras instituições, como a família, a escola e a mídia. As telas tornam-se dispositivos de produção e modelação das subjetividades, onde as pessoas estão dispostas aos fluxos informativos (SPEROTTO, 2009).

3.5 Interfaces digitais e aparelhamento digital

É comum, na pós-modernidade, a sensação de que conhecimento é ciência, principalmente na sociedade da informação, onde as TDIC desempenham grande relevância na produção do conhecimento. O conhecimento, em uma abordagem das TDIC, ganha uma dimensão espacial infinita, trazendo uma implicação social: o valor da neutralidade social como quadro referencial desse conhecimento (BAUMAN, 2001).

O que criticamos é justamente tal neutralidade, visto o conhecimento ser sempre localizado e politicamente posicionado. A neutralidade social do conhecimento oferece uma ideia de que ele é uma produção distribuída de modo justo, igualitário e disponível para todos. Acontece que o conhecimento é distribuído geopoliticamente, bem como as TDIC o são. Eles são pensados em uma lógica de desigualdade social e de classe social, contribuindo para a reprodução de juízos pessoais e modos sociais excludentes (SANTOS, 2006).

Nesse cenário, as experiências cotidianas - aqui damos ênfase às sociais e pedagógicas - acabam sendo moduladas em função desse mesmo conhecimento com sua pretensa neutralidade social, mas potencialmente carregado de vieses ideológicos e visões de mundo que coadunam com o capital e os valores pósmodernos. O tempo acelerado, a ampliação da noção de espaço - ou mesmo a virada do espaço físico para o virtual -, os fluxos (in)constantes de pessoas e suas relações com o capital, a modernização e seu projeto civilizador transbordante de ideias consumistas e uma lógica de mercado que regimenta os processos sociais e de formação humana, são desafios postos pela noção de experiência contrahegemônica.

Para se combater tais essas questões mecânicas pós-modernas do social, recorremos a Bondía (2002) que nos mostra o cotidiano como sendo robustamente marcado pelos acontecimentos humanos, tantas vezes sem sentidos, e que se 
relacionam com a satisfação imediata das necessidades. Parece mesmo que o cotidiano é a própria efervescência do imediatismo. Grande é o fluxo de informações confundidas com conhecimentos neutros, bem como a reelaboração de relações sociais sem mediação cultural e politicamente humana. O cotidiano pós-moderno é próprio das máquinas que comandam as escolhas humanas, que emitem linguagens, que decidem nossos passos; máquinas que se confundem com a própria noção de humano, que interliga inteligências artificial e humana, que dotam o humano de dimensão ciborgue (DELEUZE; GUATTARI, 2010; HARAWAY, 1994).

A valorização de uma experiência contra-hemegônica - porquanto longe daquela que atravessa o imediatismo pós-moderno - é uma expressão sociológica de intensa luta contra os desafios mecânicos postos na pós-modernidade. Assim, a experiência, como lugar dos acontecimentos sentidos, atravessados, mediados e politicamente refletidos, é um enfrentamento ao presente pós-moderno. Podemos mesmo dizer que é um movimento esquizo ${ }^{6}$, que pretende deslocar as estruturas que nos movem na contemporaneidade. $O$ mundo e a realidade passam a ser mediados por sentidos humanos: tateamos, olhamos, sentimos cheiro, sons, imaginamos, problematizamos, produzimos o cotidiano histórico e material. É a possibilidade de rompimento com a lógica mecânica da pós-modernidade. Renovamos o mundo com a capacidade do sentir (BONDÍA, 2002).

As experiências tornam-se singulares, nesse sentido, porque são ímpares e mediadas. Lançamo-nos em incertezas, em mistério, em ativa participação no social e na vida. A aventura do cotidiano acaba forjando relações sociais cada vez menos mecânicas, automáticas. Benjamin (1992) nos alerta para nossa capacidade humana e social de compartilhar as experiências. Isso nos torna menos alienados e desterrados de uma lógica mecânica; passamos a ser artistas do cotidiano. Por meio da técnica, o humano vai se tornando distante da experiência e vai dotando seu corpo de uma capacidade-máquina. Não vivemos a morte da experiência na pósmodernidade, mas dela nos aproximamos.

Quando tratamos das TDIC, a capacidade de nos tornarmos em máquinas e distantes da experiência é potencializada. Miskolci (2016) nos mostra que o acesso a computadores de mesa e à conectividade via telefônica reestabeleceram outras

\footnotetext{
${ }^{6} \mathrm{O}$ termo exprime a ideia de separação, divisão, desagregação. Utilizamos para afirmar a ruptura com as estruturas hegemônicas postas como legítimas. Ao romper com tais estruturas, somos considerados dissidentes do que é compreendido como sendo verdadeiro.
} 
relações sociais, chegando à construção de relações em rede. Como a forma de produção de conhecimento é geopolítica e assimétrica, o acesso aos equipamentos não se dava de modo justo. Tanto o custo do acesso e manutenção à internet, como também as interfaces mais estáticas e menos interativas das TDIC, acabaram por elitizar um grupo que acessava e dominava os conteúdos e usos da internet, das TDIC e das redes sociais.

Essa minoria privilegiada acabou acumulando capital econômico, cultural e social. Contudo, houve um momento de popularização da internet e das interfaces digitais. O acesso tornou-se mais barato, as interfaces mais atrativas e dinâmicas e as redes sociais foram sendo capilarizadas, provocando mudanças significativas nos processos de subjetivação dos indivíduos. Afirma Miskolci (2016, pp. 280-281):

\begin{abstract}
No início do milênio, o acesso passou a se dar cada vez mais por banda larga e a interface da rede se tornou mais amigável para que os usuários passassem a ser criadores de conteúdo. A chamada Web 2.0 tornou possível o sucesso das plataformas que conhecemos como redes sociais, como o antigo Orkut e o atual Facebook. Além dessas melhoras na rede, na qualidade e velocidade, no barateamento dos equipamentos, dois outros fatores articulados e indissociáveis permitiriam que a rede alcançasse a maior parte da população brasileira em 2014: o crescimento econômico baseado na inserção das classes populares no universo do consumo, o que disseminou a telefonia celular com acesso à rede entre os mais pobres.
\end{abstract}

Ainda para Miskolci (2016), no Brasil, os telefones - do tipo smartphones foram responsáveis por popularizar as tecnologias digitais da comunicação de modo integrado, em rede. Com preços acessíveis e também com interface simples, a navegação na rede mundial de computadores permitiu a experiência do imediatismo, do fluxo constante de informações, da integração em rede, do compartilhamento do tempo e espaço da cibercultura. Faz parte desse movimento uma demanda social cada vez maior pela inclusão tecnológica. Como percebemos, essa demanda influenciou os processos identitários dos sujeitos.

Emerge disso a realidade de uma linguagem digital. Uma linguagem que gera uma realidade de mundo histórico: a era digital. A era digital abriu possibilidade de novas formas de comunicação existirem. Novos conhecimentos são produzidos e levados a quaisquer lugares. Há uma passagem do físico para o virtual de modo radical. Quem não acompanha essa automatização é deixado para trás. Nesse processo do virtual, as interfaces digitais passam a não apenas vigiar todo o cotidiano dos atores sociais, mas de modelar suas ações. Pelas interfaces digitais, o humano 
vai acoplando em si mesmo as TDIC e criando em si um ciborgue que tem o mundo mediado pela força e potência dos aparelhos digitais.

Ao invés de experiências sensíveis, as experiências imediatas levam o sujeito a perceber o mundo, principalmente, pela linguagem virtual. $O$ mundo virtual, para Lévy (2011) é potencialmente ágil. Nisso, a virtualização do mundo físico configura novas formas de força e finalidade. Otimista dos processos de virtualização, o autor nos mostra que há mais benefícios do que malefícios em virtualizar o mundo físico. Não entramos nesse mérito polarizador, mas problematizamos a virtualização do seguinte modo: em que medida estamos deixando nossas potências humanas - e, portanto, sensíveis - para sentir o mundo por meio das interfaces digitais e de seus aparelhos? A polarização trazida por Lévy (2011) não contribui para avançarmos na discussão. Por isso propomos pensar que não se trata de julgar as interfaces digitais e os processos de virtualização do mundo físico enquanto bom ou não, mas de perceber quais valores estão atrás desses fenômenos.

Qual seja a revolução, trará consigo implicações. Nesse sentido, a era digital implica em reverberações nas relações sociais. Alguns valores como dinamismo, imediatismo e a facilidade na difusão das informações são fundamentais para pensarmos as relações sociais, os processos de subjetivação na pós-modernidade, bem como para analisarmos sociologicamente a categoria das interfaces digitais e sua influência no conhecimento que o sujeito tem de si e do mundo. A própria comunicação é afetada por tais valores. Parece mesmo existir uma disputa entre os sujeitos para estar, a todo momento, e em qualquer lugar, pronto para comunicar as informações que lhes chegam, sem o cuidado de mediar essas informações, seja pela experiência no sentido benjaminiano, seja por critérios racionais mais críticos.

O acoplamento dos aparelhos digitais ao próprio sujeito como forma de conhecer o mundo, sendo formatado e mediado pelas interfaces digitais - e a isso denominados aparelhamento digital - parece levar a materialização da era digital. Pouco interessante que resulta desse fenômeno a busca pela velocidade cada vez maior na troca das informações. Ercilia (2000, p. 12) nos diz que: "Já estamos presenciando hoje, após pouco tempo, uma grande aceleração na difusão de informação. Nunca tantos livros, jornais, revistas, músicas e informações de todo tipo foram acessíveis tão rapidamente a um número tão grande de pessoas como hoje". A era digital chegou e com ela as novas formas sociais de produzir sentidos. $O$ 
aparelhamento digital, enquanto fenômeno dessa era, mecanizou nossos processos de subjetivação e nossas relações com o outro e com o mundo.

Parte aparente disso é que, segundo Negroponte (1995), no social, tudo passa a ser bit $^{7}$. Dito de outro modo: tudo passa a ser digital, inclusive a própria relação de construção do social. Do mesmo modo:

Compomos com bits as imagens, textos, sons, agenciamentos nos quais imbricamos nosso pensamento ou nossos sentidos [...] o digital é uma matéria, se quisermos, mas uma matéria pronta a suportar todas as metamorfoses, todos os revestimentos, todas as deformações (LÉVY, 2010, p. 103, grifo nosso).

Atentem que nossos agenciamentos passam a ser também digitais. É nessa ordem que formas outras de existir socialmente são elaboradas quando os aparelhos digitais e suas conectividades mediam nossa relação com o mundo. A era digital propõe - ou impõe - o aparelhamento digital como centro dos processos de subjetivação. Quando pensamos o social, e dentro dele a educação, precisamos refletir com bastante força crítica as implicações desse aparelhamento digital nos processos formativos.

O digital é redimensionado; ele leva as pessoas a interagirem em rede e constantemente. Não se trata de vê-lo de modo polarizado: ou bom ou mal. Trata-se de ponderar, como afirma Lévy (2011, p. 22): "Cada novo sistema de comunicação e de transporte modifica o sistema das proximidades práticas, isto é, o espaço pertinente para as comunidades humanas". O digital traz benefícios quando usados de modo crítico, sem perder de vista a experiência de estar no mundo.

As TDIC e as interfaces digitais trouxeram mudanças para nossa sociedade. A internet dinamizou o social e nisso temos que pensar em como a conectividade, seja nos aparelhos celulares, nas TVs ou outros dispositivos, permite a alienação de nós mesmos, buscando sempre a construção da experiência de mundo.

\subsection{O lugar da educação no contexto do aparelhamento digital}

Pierre Bourdieu elaborou teorizações complexas sobre as relações sociais e, consequentemente, sobre as estruturas sociais. Sua reflexão crítica acerca das estruturas sociais nos ajuda a compreender, com profundidade e rigorosidade

\footnotetext{
${ }^{7}$ Menor unidade de medida da informação. Pode ser armazenada e transmitida.
} 
epistemológica, questões que se ligam à sociologia da educação. Ao identificar o que o senso comum não conseguia olhar com criticidade, Bourdieu elaborou um sistema teórico capaz de evidenciar e denunciar as condições de participação social dos indivíduos. Essa participação social é baseada na herança social, que ele chama de estrutura estruturante (BOURDIEU, 1989).

Para entendermos a estrutura estruturante, temos que entender a sociedade e suas profundas relações. Constantemente a sociedade consegue reestruturar-se a partir das ações dos indivíduos, de modo que o acúmulo dos bens simbólicos, especialmente a educação, concentra-se no pensamento dos indivíduos na forma de estruturas. Também, os bens simbólicos são concentrados nas manifestações dos indivíduos e em suas ações (BOURDIEU, 1989).

Para melhor entendermos, Bourdieu nos oferece os conceitos de campo e de habitus. O campo representa um espaço atravessado e demarcado por dominação, conflitos, interesses e tensões; o campo educacional é um exemplo desse espaço. Cada campo existente apresenta certa autonomia, possui regras elaboradas de organização e de hierarquia social.

Os campos são limitados, pois os indivíduos atuam conforme seu capital social. Dito de outro modo: as possibilidades que possuem os indivíduos advêm da rede de contatos onde está localizado o indivíduo. É mesmo uma relação dialética entre sujeito e sociedade que se abre em uma via de mão dupla: a ação do sujeito e a estrutura do campo, socialmente determinados.

Ainda sob esse ponto de vista, ações, comportamentos, escolhas e tudo que envolva a subjetividade do indivíduo não surge de cálculos e planejamentos, mas são produtos do habitus. Esse conceito nos leva a entender que os indivíduos elaboram suas trajetórias e percursos sociais, da mesma forma que tais trajetórias e percursos são modos de reprodução social.

A reprodução, entretanto, não se realiza sem a sutileza dos agentes da ação e das instituições. Com isso queremos dizer, conforme Bourdieu (1989), que as funções sociais, bem como suas interações que permitem o indivíduo pensar, sentir e agir em diferentes contextos sociais, são determinadas pelo habitus. Este traduz os estilos de vida, e os diversos posicionamentos do indivíduo. Também é o meio pelo qual se cria ou desenvolve estratégias individuais e coletivas (BOURDIEU, 1989).

Importante também é, em Bourdieu (1998), a categoria de capital cultural. Esse conceito é ligado à escolaridade nos trabalhos do sociólogo. Refere-se aos 
dispositivos técnicos e simbólicos que o sujeito adquire em seu meio social. Ainda: é o conjunto de diplomas, dos diversos níveis de conhecimentos gerais, bem como as experiências artísticas, estéticas, linguísticas e de etiqueta. Difere-se do capital econômico e do capital social. O primeiro se relaciona com as posses financeiras e bens adquiridos pelo sujeito; o segundo é o conjunto de relações sociais que o sujeito articula com outros sujeitos.

Para Bourdieu (1998), os estudantes de classe média, assim como da alta burguesia, estão em maior proximidade com a cultura tomada como erudita. Pelas práticas culturais, políticas, sociais, linguísticas e artísticas que atravessam a família da classe média, os estudantes dessa camada social apresentam maiores chances de sucesso escolar. Há uma estreita relação entre cultura e desigualdade escolar. A escola, demanda de seus estudantes, competências que são construídas no seio familiar e no meio social, de modo que tais competências são mais presentes, de modo hegemônico, podemos afirmar, nas famílias de classe média e da alta burguesia.

Vasconcellos (2002) nos mostra que a violência simbólica, conceito da sociologia de Bourdieu, contribui para entendermos os mecanismos que fazem com que sujeitos sejam subordinados e aceitem com naturalidade as representações e as ideias dominantes da burguesia. A violência simbólica é desenvolvida pelas instituições e agentes que as colocam em prática e, por isso mesmo, exerce autoridade. Através da cultura escolar, regras, valores e comportamentos da classe dominante, são postos e demandados nas classes populares. Por meio de conteúdos, programas, métodos pedagógicos e de avaliação, a violência simbólica se materializa e cria uma cosmologia de mundo a partir da cultura imposta por classes dominantes. De modo natural, regras, sanções, punições, direito, moral e linguagem dominantes são aceitas pela classe popular.

Trazemos todos esses conceitos bourdianos para anunciar a grande denúncia de Bourdieu (1998) quanto à escola: a escola legitima e reproduz as desigualdades sociais. Perdendo seu papel de instituição transformadora e democrática, a escola passa a ser uma das principais instituições e estrutura social que legitima privilégios sociais e reproduz as ideologias morais, sociais, políticas, estéticas e filosóficas das classes dominantes. Martins, Nogueira e Nogueira (2002) nos mostram que os alunos não são, contudo, sujeitos abstratos que competem de forma igual na escola. Cada 
um carrega uma bagagem cultural e social que é cooptada pela escola e passa a ser contextualizada para a economia e para os sentidos da existência social.

Nesse sentido, podemos pensar que as visões de mundo das classes dominantes são contextualizadas e impressas nos estudantes de classe popular a partir das experiências sociais e culturais que esses estudantes já carregam. Para além disso, o que se pensa, se pretende e se faz do mundo é também impresso nas experiências dos estudantes. É dessa forma que Bourdieu (1998) diz que a escola não é neutra. O que reproduz, o que legitima é posto desde as necessidades e demandas ideológicas das classes dominantes. Assim,

É provável por um efeito de inércia cultural que continuamos tomando o sistema escolar como um fator de mobilidade social, segundo a ideologia da escola libertadora, quando, ao contrário, tudo tende a mostrar que ele é um dos fatores mais eficazes de conservação social, pois fornece a aparência de legitimidade às desigualdades sociais, e sanciona a herança cultural e o dom social tratado como dom natural (BOURDIEU, 1998, p. 41).

O sujeito é um ator minimante detalhado e configurado social e culturalmente. Tudo é construído socialmente. As escolhas, os comportamentos, as ações, as afetividades, nada foge da construção social. Nisso, a formação inicial do sujeito se dá nos ambientes familiar e social. Esses ambientes compõem uma estrutura social específica, onde os sujeitos incorporam disposições que os direcionam a ações específicas e típicas da posição em que ocupam. Constitui um habitus familiar ou de classe, que o conduz ao longo de suas experiências em diferentes ambientes. A estrutura social se perpetua quando os próprios sujeitos tendem a reconfigurá-la e atualizá-la conforme a posição estrutural na qual foram eles são socializados (MARTINS; NOGUEIRA; NOGUEIRA, 2002).

Pensamos então, a partir dessas construções conceituais, que os indivíduos são caracterizados pela herança socialmente recebida. Essa herança inclui objetivos alheios ao sujeito. Exemplo disso é o capital econômico que permite o acesso a serviços específicos e o capital social, cujo conjunto de relações sociais mantido pela família permite certas relações sociais. Essa herança social do capital econômico e cultural criam referências culturais e de conhecimentos que legitimam uma linguagem própria, na medida em que a linguagem é uma forma de cosmologia social. Pela linguagem $o$ sujeito cria realidades, $o$ real e produz conhecimentos (VASCONCELLOS, 2002). 
Assim, o capital social, enquanto conjunto de recursos potenciais ligados à posse de relações aproximadamente institucionalizadas e que geram interconhecimento e inter-relação, representa a vinculação a um grupo, a um grupo de agentes que para além da ideia de posse de propriedades comuns, se unem por ligações úteis, pragmáticas e que, por consequência, são valorizadas dadas ao valor de utilitarismo, onde os agentes do mesmo se beneficiam mutuamente. Essas ligações são fundadas em trocas materiais e simbólicas, cujos processos de instauração e de perpetuação supõem o pleno reconhecimento dos agentes que participam das trocas (BOURDIEU, 1998).

Ao existir uma rede colaborativa e relacional, não se estabelece o caráter natural dessa rede, semelhante à rede familiar, mas se intui a construção normatizada e social dessa rede. Se a família é construída através de uma genealogia de parentesco, em muitos casos, a rede colaborativa social é tecida em contextos socialmente estabelecidos e simbolicamente favorável para os membros desta rede. É um trabalho de criar e manter as coisas necessárias para produzir e reproduzir relações duráveis e, sobretudo, úteis, com objetivo de possibilidade real de lucros materiais e simbólicos (VASCONCELLOS, 2002).

A rede de ligações constitui-se em uma estratégia de investimento social orientado para a reprodução das relações sociais. Nela, se estabelece afetividade, intersubjetividades, moral, ética e outros aspectos estruturantes que são próprios do grupo ideológico e social a que pertence os sujeitos. Há também garantias institucionais, os direitos. As trocas entre os membros são realizadas em palavras e em atos materiais. Nos diz Bourdieu (1998, p. 68):

\footnotetext{
A troca transforma as coisas trocadas em signos de reconhecimento e, mediante o reconhecimento mútuo e o reconhecimento da inclusão no grupo que ela implica, produz o grupo e determina ao mesmo tempo os seus limites, isto é, os limites além dos quais a troca constitutiva, comércio, comensalidade, casamento, não pode ocorrer. Cada membro do grupo encontra-se assim instituído como guardião dos limites do grupo.
}

O capital cultural é incorporado à realidade escolar, distinguindo-se nas formas de estado incorporado, estado objetivado e estado institucionalizado. No estado incorporado, o capital cultural apresenta-se sob disposições duráveis através do próprio organismo do indivíduo. O ter acaba se tornando um ser, algo realmente corporificado e parte da pessoa. Tal capital não é transmitido de modo instantâneo, mas, diferente do dinheiro, por exemplo, é adquirido de forma inconsciente. Bourdieu 
(1998, p. 75) nos diz: "Não pode ser acumulado para além das capacidades de apropriação de um agente singular; depaupera e morre com seu portador, com suas capacidades biológicas, sua memória, etc".

O estado objetivado é apresentado sob os bens culturais. O capital cultural, nesse estado, contém certas propriedades que se definem somente na relação com o estado incorporado. Sobre isso, Bourdieu (1998, p. 78) afirma:

O capital cultural no estado objetivado apresenta-se com todas as aparências
de um universo autônomo e coerente que, apesar de ser o produto da ação
histórica, tem suas próprias leis, transcendentes às vontades individuais, e
que permanece irredutível, por isso mesmo, àquilo que cada agente ou
mesmo o conjunto dos agentes pode se apropriar.

A existência desse capital cultural nesse estado só é possível como um capital ativo e flutuante, material e simbolicamente; é condição de ser apropriado por seus agentes e assim, usado como arma e objeto de lutas travadas no campo cultural. Além disso, no que se refere às classes sociais, os agentes são beneficiados, proporcionalmente, ao domínio que possuem de tal capital, na medida do capital incorporado (BOURDIEU, 1998).

Sobre o estado institucionalizado, Bourdieu (1998, p. 79) nos diz:

\begin{abstract}
Ao conferir ao capital cultural possuído por determinado agente um reconhecimento institucional, o certificado escolar permite, além disso, a comparação entre os diplomados e, até mesmo, sua 'permuta' (substituindoos uns pelos outros na sucessão); permite também estabelecer taxas de convertibilidade entre o capital cultural e o capital econômico, garantindo o valor em dinheiro de determinado capital escolar.
\end{abstract}

Esse estado é uma forma de objetificação que é colocada à parte. Isso porque é o tipo que confere ao capital cultural suas propriedades originais. Para fecharmos nossas teorizações a partir de Bourdieu (1998), repensamos a violência simbólica como demarcada na estrutura social, definida e sustentada por princípios e bases hegemônicas. O poder simbólico do capital econômico exerceu influência nos vínculos sociais e nas relações advindas deles. Os hábitos cultivados pela elite foram postos como sendo os melhores hábitos, comportamentos e estilos de vida, definindo os espaços sociais e suas interações.

A educação, nesta perspectiva, foi pensada a partir dos interesses da elite. A elite viu possibilidade de ganhos pela educação e seus princípios burgueses, de forma que o capital cultural se une ao capital econômico. O capital cultural, imprescindível 
para formamos nossas visões de mundo, foi vinculado às condições da classe dominante. Assim, pensar a educação é um movimento de refletir sobre o que é posto como naturalizado, sobre as violências simbólicas perpetradas e perpetuadas contra as classes populares, bem como sobre as intencionalidades, metodologias, didáticas e pedagogias em torno do que se pretende ensinar. 


\section{FUNDAMENTAÇÃO TEÓRICO-METODOLÓGICA}

Assumimos o caminho apontado por Severino (2007) que nos mostra que não basta em uma pesquisa seguir o método. É preciso um fundamento epistemológico que fundamente o método; é preciso que haja uma concepção filosófica sobre a relação sujeito e objeto. Toda escolha metodológica envolve uma posição epistemológica e política, de modo que a pretensa neutralidade do sujeito sobre o objeto é uma metanarrativa. Nos diz Severino (2007, p. 107):

O homem se constitui então como um organismo vivo, regido pelas leis da natureza, tanto no plano individual como no social, leis que determinam sua maneira de ser e de agir. Assim, os valores e critérios de sua ação se encontram expressos na própria natureza sob a forma de leis de funcionamento que se pode conhecer pelas várias ciências, aplicando-se o método científico, simultaneamente experimental e matemático.

É assim, que antes de concebermos nossas escolhas teórico-metodológicas, assumimos uma posição quanto à perspectiva de conhecimento do objeto de pesquisa deste trabalho. Primeiro, pensamos a questão da linguagem, pois é este fenômeno que atravessa com grande força e influência o objeto a ser investigado. Entendemos que a linguagem é uma forma de interação entre sujeitos que tem o objetivo de comunicar. A função da linguagem, além da comunicação, tem a função de regrar comportamentos e se aplica ao planejamento da ação (VYGOSTSKY, 1991).

Na compreensão de Bakhtin e Volochínov (1988), a língua tem sua verdadeira centralidade enquanto um fenômeno social de interação, de modo que ela só é possível na interação entre sujeitos. A comunicação torna-se um processo interativo, complexo, rompendo com a simples transmissão de informações, como explica Bakhtin e Volochínov (1988, p. 123):

A verdadeira substância da língua não é constituída por um sistema abstrato
de formas linguísticas nem pela enunciação monológica isolada, nem pelo
ato fisiológico de sua produção, mas pelo fenômeno social da interação
verbal, realizada através da enunciação ou das enunciações. A interação
verbal constitui, assim, a realidade fundamental da língua.

Não há como produzir linguagem fora da interação entre os sujeitos. Essa concepção permite entender a linguagem como organização discursiva conforme as intencionalidades e os contextos socioculturais e históricos onde se inserem os sujeitos. Para Koch e Elias (2010, p. 10-11): 
Na concepção interacional (dialógica) da língua, os sujeitos são vistos como atores/ construtores sociais, sujeitos ativos que - dialogicamente - se constroem e são construídos no texto, considerando o próprio lugar de interação e da constituição dos interlocutores. Desse modo, há lugar, no texto, para toda uma gama de implícitos, dos mais variados tipos, somente detectáveis quando se tem, como pano de fundo, o contexto sociocognitivo dos participantes da interação.

É na interação com o outro que o sujeito cria a linguagem. É assim que os sujeitos podem ser compreendidos como construtores sociais. Na interação social e verbal, nos diálogos e nas produções textuais, as trocas culturais e sociais de conhecimentos são estabelecidas, fornecendo pistas para a descoberta dos sentidos ocultos na linguagem.

O sujeito que fala e/ou produz textos, produz ações de elaboração de significados através da linguagem, realizando o contato com o outro que escuta ou lê o texto produzido. Essa ação se constitui enquanto compromisso e vínculo social que não existiram a não ser por meio da intenção do ato de produzir textos ou da fala (GERALDI, 1984).

Posicionamo-nos ainda a favor de que o Ensino de Sociologia ofereça recursos cognitivos, emocionais, culturais e metodológicos para que os estudantes construam um olhar e pensar sociológico sobre o mundo à sua volta. Esse olhar e esse pensar sociológico são fundamentais para a formação crítica. Além disso, o olhar e pensar sociológico são mediados pela linguagem. Por isso que trazemos uma concepção de linguagem enquanto um fenômeno social de interação entre os indivíduos. Pela linguagem, o indivíduo organiza suas experiências sobre o mundo (MORAES, 2014; OLIVEIRA, 2011).

Ao estudar os fenômenos sociais, buscamos conceber e compreender as regularidades da vida social. É uma investigação sobre as relações entre os sujeitos e os elementos que compõem o mundo social (BOURDIEU; CHAMBOREDON; PASSERON, 2000). Há nesse movimento uma tentativa de superar o senso comum. É a formação de uma consciência crítica e de uma imaginação sociológica (MILLS, 1969) que acabam construindo enfrentamentos sobre o mundo, problematizações sobre a história e que produz conhecimentos e experiências singulares. Assim, ao entendermos que o objeto de pesquisa deste trabalho é atravessado pela linguagem, então surge uma nova questão: como essa linguagem é afetada pelas tecnologias digitais da informação e comunicação? 
Quando levantamos esse questionamento, percebemos que o pensamento sociológico, assim como o olhar sociológico, demanda complexidade, especialmente no contexto desta investigação, a lembrar: o aparelhamento digital e suas implicações para o ensino de Sociologia. É uma relação que requer uma postura reflexiva, uma práxis epistemológica de estranhamento, que desnaturalize as tecnologias digitais da informação e comunicação na educação como modo de repensar e avançar o estudo sobre essas tecnologias.

O estranhamento é uma posição investigativa de desconstrução, de desnaturalização do modus operandi das tecnologias digitais da informação e comunicação que nos desloca sociologicamente e nos faz questionar de que modo o Ensino de Sociologia pode ser afetado pelas TDIC. Também, avançamos e chegamos a questionar como os indivíduos têm se relacionado socialmente dentro do contexto de mediação da linguagem pelas TDIC.

É esse estranhamento que desparamenta, desconfigura e desmonta os indivíduos aparelhados, que interagem, realizam trocas, produzem símbolos e novas formas de existir mediadas por tecnologias e situadas no ciberespaço. Com isso, queremos afirmar que a interatividade entre a objetividade e as subjetividades dos indivíduos aparelhados digitalmente contribui para uma linguagem capaz de interpretar um novo cotidiano. Isso converge para o que aponta os Parâmetros Curriculares Nacionais para o Ensino Médio (BRASIL, 1999, p. 42):

\footnotetext{
A objetivação implica a exteriorização da realidade, a partir da institucionalização (consolidação de um padrão pela tradição), da configuração de papeis sociais (tipificação de formas de ação) e da legitimação dos universos simbólicos e seus respectivos mecanismos de manutenção. A subjetivação implica a interiorização da realidade, através do processo de socialização.
}

Ao entendermos essa dinâmica de estranhamento, que nos leva a refletir sobre a relação e interação entre objetividade e subjetividades, o Ensino de Sociologia perpassa o entendimento da natureza social, torna-se uma prática transformadora, transgressora de métodos que pretendem o domínio da subjetivação.

Especialmente no Ensino Médio, seu caráter deveria ser reflexivo, desnaturalizante, de estranhamento da realidade social. Seu desafio é, portanto, explicar o mundo a partir das construções subjetivas que naturalizam as coisas sociais. Em oposição a isso, o Ensino de Sociologia, na perspectiva do Novo Ensino Médio, não deve priorizar uma formação de enfrentamento à naturalização social, 
"Afinal, não se deve pretender formar "jovens historiadores"; "jovens geógrafos"; "jovens filósofos"; "jovens sociólogos” etc., na escola de Ensino Médio. Não são essas as finalidades desse segmento de ensino" (BRASIL, 2019, p. 22).

Percebemos a postura de distanciamento da formação crítica e social do estudante do Novo Ensino Médio. Evidente que a formação de geógrafos, historiadores, filósofos e sociólogos acontece no Ensino Superior. Reclamamos apenas a falta da concepção de uma formação crítica, histórica e reflexiva em detrimento de uma formação voltada para uma pedagogia de competências, que em sentido amplo pretende a alfabetização técnica, social e conceitual.

Uma alternativa possível, e uma chave de leitura sociológica, é trazida por Oliveira (2011) que destaca a importância de uma posição teórico-metodológica capaz de criar sentidos mais amplos e não universais, mais plural e menos reducionista. Assim, compreendemos, na mesma direção do autor, que a realidade constitui o sujeito, ao mesmo tempo em que o sujeito social constitui a realidade.

Há a necessidade de uma problematização para construção dos objetos sociológicos e de "[...] o caráter também político e ideológico, não sendo uma simples descrição refinada da realidade, mesmo que o fosse, estaria mediada por todas estas questões" (OLIVEIRA, 2011, p. 06).

Desse modo, realizamos uma incursão metodológica, apoiada nesses argumentos e nesse enfrentamento epistemológico sobre a concepção de Ensino de Sociologia no Ensino Médio, capaz de contestar e disputar uma perspectiva sociológica mais genuína e comprometida com a investigação social do cotidiano que consiga ir além da simples "[...] ação de cunho interdisciplinar que articula o trabalho das disciplinas, no sentido de promoverem competências" (BRASIL, 2019, p. 14).

Essa questão nos impulsiona a entender todas as nossas escolhas teóricometodológicas. Em verdade, essa contextualização nos mobiliza a persistir em uma metodologia também crítica, politicamente engajada em uma visão de mundo, e pretensiosamente não neutra (SEVERINO, 2007). Nos termos de Thiollent (1980), a pesquisa sociológica não nega a influência da posição, histórica e biográfica, do pesquisador. Tampouco nega seus interesses e seus preconceitos. A neutralidade não existe, vai nos dizer Becker (1977), na pesquisa em Sociologia; a objetiva é puramente relativa.

Não queremos com isso negar o rigor metodológico, mas realizar um enfrentamento metodológico que possa perceber o objeto de pesquisa desta 
investigação a partir de desnaturalização e da construção do olhar e do pensamento sociológico genuíno. É um movimento de compromisso com visões de mundo, com propostas críticas e libertadoras; no sentido mais geral, é um movimento de transgressão. Aqui reside a originalidade da pesquisa em Sociologia.

\subsection{Campo de pesquisa}

A pesquisa foi realizada em uma escola pública da rede estadual de ensino, localizada na cidade de Arcoverde - PE. A escola pela cidade e pela escola dá-se em função da necessidade de interiorizar as pesquisas sociológicas e de visibilizar outros e novos campos de pesquisa que não são tão presentes na academia.

\subsection{Abordagem da pesquisa}

Diante dos pressupostos teóricos trazidos acima, nossa proposta teóricometodológica busca os significados implícitos no fenômeno a ser estudado. Para Minayo (1996), a pesquisa qualitativa em Sociologia trabalha com significados, motivações, valores e crenças, sendo que estes não se reduzem aos aspectos quantitativos, já que respondem a compreensões particulares.

A pesquisa qualitativa permite que o pesquisador possa emergir no mundo dos sujeitos observados. Pretende-se compreender os sentidos, os significados que estão ao redor dos fatos e do cotidiano. Assim, diante do nosso objeto de pesquisa, objetivamos conhecer alguns sentidos que se colocam atravessados no cotidiano da escola e da prática dos sujeitos participantes da pesquisa.

Severino (2007) nos ajuda a pensar a pesquisa qualitativa por meio de outra compreensão que não seja a pesquisa em si mesma e a sua modalidade de metodologia. Assim, o autor recomenda a expressão abordagem qualitativa para se referir aos conjuntos de metodologias e suas diversas referências epistemológicas. $A$ abordagem qualitativa é uma referência epistemológica capaz de estruturar cada escolha metodológica a partir dos sentidos e significados que se busca conhecer.

Quando elegemos a abordagem qualitativa para esta pesquisa, realizamos uma reflexão sobre o objeto de pesquisa. Também, pensamos que o fazer ciência, na perspectiva qualitativa, privilegia a análise dos microprocessos, ou seja, é mesmo um 
estudo sobre as ações sociais, individuais e grupais. A abordagem qualitativa ainda permite um intenso exame dos dados, demarcando sua profundidade e convergindo para a discussão das unidades sociais (THIOLLENT, 1980).

Thiollent (1980) nos apresenta a flexibilidade quanto à escolha dos procedimentos de coleta de dados em uma pesquisa qualitativa. Essa flexibilidade é importante para uma pluralidade interpretativa e para a plasticidade do trabalho com os dados. Não se configura em uma rede infinita de interpretação sobre os dados, mas de compreender que mantemos uma relação de proximidade com o fenômeno que é contextual. O conhecimento então, é relacional e interativo, e não completo e estático.

Por fim, justificamos nossa escolha por essa abordagem porque ela é realizada com a intuição, a imaginação e a experiência do pesquisador, como mostra Nisbet (2000). Essas capacidades são essenciais para o trabalho sociológico e são definidoras de um trabalho intelectualmente artesanal, lapidado e liberto.

\subsection{Tipo de pesquisa}

Em relação aos objetivos apresentados nesta pesquisa, realizamos uma escolha metodológica quanto ao tipo de pesquisa. Pretendemos, segundo análise dos objetivos, conhecer as causas e as relações do fenômeno. Buscaremos compreender o fenômeno do aparelhamento digital, suas características, suas relações com a cibercultura e os cenários de aprendizagem. A partir disso, exploraremos a discussão sobre as novas subjetividades no contexto pós-moderno e realizaremos interpretações sobre como as aulas de Sociologia são influenciadas pelo aparelhamento digital.

Diante disso, optamos pela pesquisa do tipo exploratória, visto que se aproxima melhor dos nossos objetivos. Segundo Severino (2007), a pesquisa do tipo exploratória busca levantar informações sobre um objeto ou fenômeno. Por meio dessas informações, o pesquisador mantém uma postura de exploração sobre a manifestação do objeto na realidade.

Richardson (2007, p. 281) nos indica que "a pesquisa exploratória procura conhecer as características de um fenômeno para procurar explicações das causas e consequências de dito fenômeno". Podemos pensar, dentro deste trabalho, que o 
caráter exploratório se dá em virtude da necessidade de descobrir os mecanismos de funcionamento do aparelhamento digital e seus desdobramentos nas aulas de Sociologia e, consequentemente, na formação de novas subjetividades nesse contexto.

Por meio do nosso Estado da Arte, percebemos que o fenômeno do aparelhamento digital é uma forma de existir na contemporaneidade e que as pesquisas são próximas dessa análise, mas não utilizam este conceito. Analisamos que outras perspectivas são investigadas, necessitando-se de um esforço sociológico sobre o tema. É dessa maneira que a pesquisa exploratória nos ajuda a discutir sobre o fenômeno a ser investigado. Ainda, sua escolha se deve também porque:

ela visa prover o pesquisador de um maior conhecimento sobre o tema ou problema de pesquisa em perspectiva. Por isso é apropriada para os primeiros estágios da investigação, quando a familiaridade, o conhecimento e a compreensão do fenômeno por parte do pesquisador são geralmente insuficientes ou inexistentes (MATTAR, 1994, p. 84).

Acreditamos, portanto, que a pesquisa do tipo exploratória coaduna com nossas intenções metodológicas de desenvolver e ampliar um olhar e pensamento sociológico sobre o fenômeno de um modo crítico, reflexivo e desnaturalizante. Assim, nossa proposta é realizar a exploração do tema, discutindo sua rede de sentidos.

\subsection{Método da pesquisa}

A falta de liberdade política e de pensamento, típica de governos autoritários, totalitários e fascistas, constrói uma realidade social constantemente vigiada. Os problemas sociais vão se amontoando, se tornando insustentáveis; surgem táticas de resistência e de enfrentamento. Há nessas táticas uma maneira de disfarçar a potência de liberdade oculta. É nessa direção que, como afirma Coelho (2012), surge a reflexão sobre o discurso social como uma produção de sentidos sobre os problemas sociais.

Durante o governo ditatorial de Franco, na Espanha, o discurso social foi constantemente vigiado. Ao mesmo tempo, uma escola sociológica espanhola começa a preocupar-se do discurso social. É esse cenário político de ditadura, resistência e estudos sociológicos sobre o real manifesto no discurso que vamos encontrar uma nova maneira de analisar o discurso (COELHO, 2012). 
Mesmo assim, esses discursos sociais guardavam em si uma realidade de resistência, de política e de cultura capaz de desvelar aquilo que estava tentando ser ocultado. Na década de 1970, a Escola Qualitativista Crítica de Madrid, em seu esforço intelectual de ocupar-se, epistemológica e metodologicamente, do real não aprendido de modo crítico, faz emergir a Análise Sociológica do Discurso - ASD. Pensada principalmente por Ibáñez (1990), o estilo de interpretação da realidade social proposta por essa análise busca um modelo de representação e compreensão do texto social, materializado, histórica e socialmente reconstruído pelos interesses dos atores envolvidos no discurso.

Conde (2009) aponta para a ASD como uma proposição hermenêutica do social capaz de vincular-se à linguagem como uma categoria de uso social. Interessante perceber que essa proposição é mesmo um trabalho socioanalítico que concebe o sujeito da pesquisa como um sujeito que produz conhecimento; rompe-se, portanto, com aquela lógica sujeito investigador e objetos investigados (IBÁÑEZ, 2010). Nessa mesma direção, como mostra Coelho (2012), essa proposta de análise permite uma intervenção social, visto que o pesquisador se transforma e transforma a ordem social. Também, o que é posto como latente, torna-se manifesto.

Para distinguir-se da análise de conteúdo e análise do discurso, Coelho (2012) aponta para algumas questões que distanciam essas análises da ASD: 1) a análise de conteúdo produz uma perda da dimensão subjetiva da linguagem. Ao fazer isso, esquece-se da produção social dos sentidos; 2) a análise do discurso mantém uma postura estruturalista de análise semiótica. A ASD não se trata de uma análise qualitativa de conteúdo, mas uma análise contextual que apresenta os sentidos que enunciam os atores sociais. De outro modo, na ASD o sujeito é recuperado no texto social.

Coelho (2012) nos mostra ainda que, influenciado por Foucault, o discurso é entendido, dentro da ASD, como uma produção e uma prática social. Distancia-se da dimensão da individualidade, portanto. Ainda: os discursos são produzidos dentro de um conjunto de ligações, de nós sociais entre os sujeitos que falam; a circulação do discurso depende da forma como a rede de relação e conflitos sociais é organizada.

Outra característica da ASD é a interpretação contextualizadora. Coelho (2012) afirma que ela é a chave de análise discursiva. Essa interpretação envolve uma reflexão em rede, pois entende diversas perspectivas que formam o contexto de formação do discurso social, tais como a cultura, a história, a linguística, o social e 
outros. Para a interpretação contextualizadora é preciso selecionar quais contextos se pretende priorizar para a análise.

Para Alonso (1998), a ADS é um esforço para recuperar os sujeitos sociais através dos discursos. Eles são entendidos como emissores, receptores e intersubjetivos que tecem o discurso e o contexto. É o sujeito social que vai do interior ao exterior, do objetivo ao subjetivo.

A partir de Godoi, Mastella e Uchôa (2018), apresentamos uma figura-esquema de como se realizar uma ASD.

\section{Figura 1 - Análise Sociológica do Discurso}

\section{Preparação do trabalho de leitura}

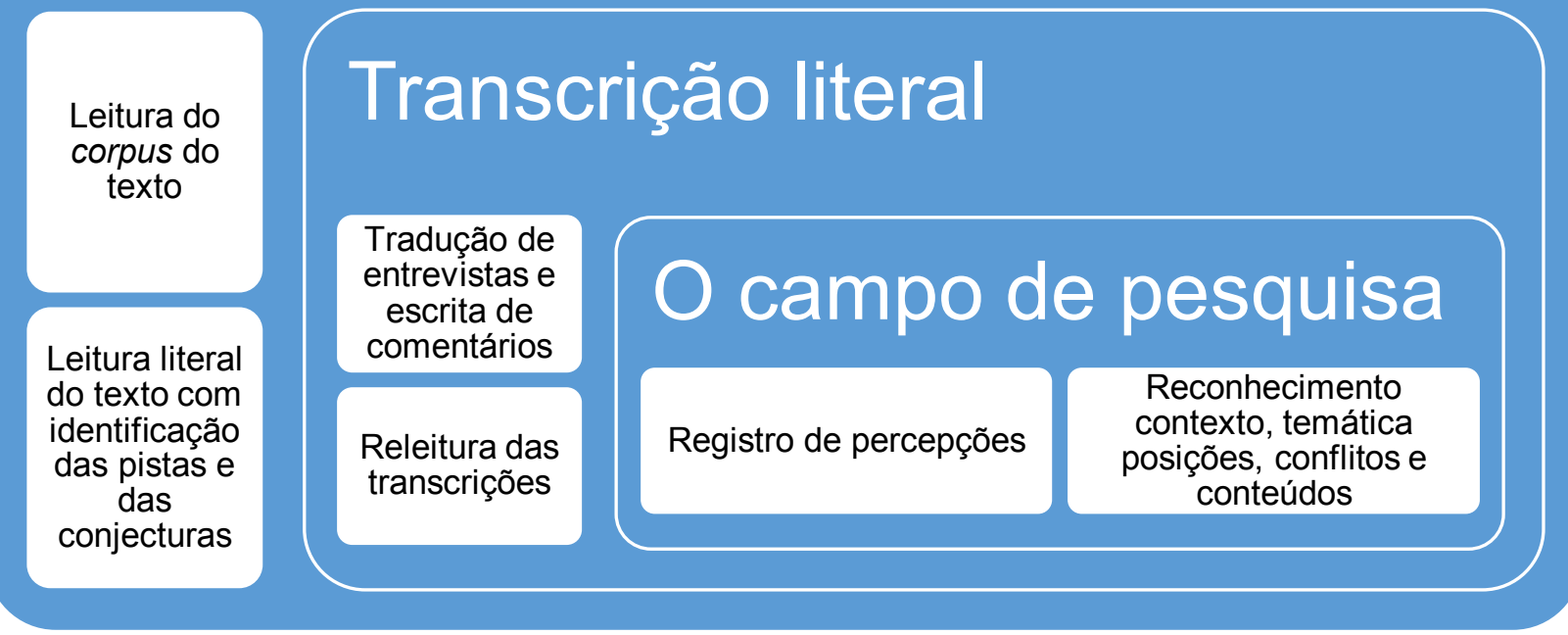

Fonte: figura-esquema adaptada de Godoi, Mastella e Uchôa (2018).

Como procedimento de interpretação na ASD, Godoi, Mastella e Uchôa (2018) recomendam produzir hipóteses que sinalizem para um sentido inicial, assim como manter uma postura atenta à literalidade do texto. Em seguida, é preciso analisar o texto como um fenômeno social atravessado por outras redes de sentidos. Para os autores, é preciso ainda analisar as enunciações, conflitos e significados postos no texto. Abaixo mostramos esse movimento em forma de figura a partir da compreensão de Godoi, Mastella e Uchôa (2018): 


\section{Figura 2 - As Direções do Discurso}

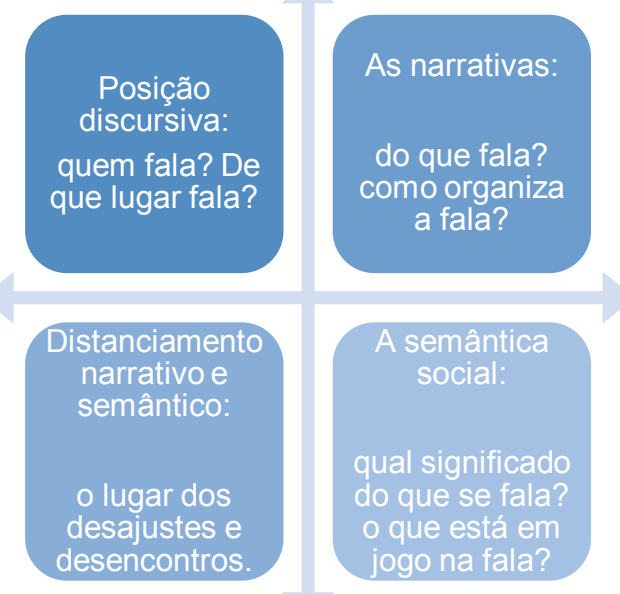

Fonte: Figura sintética adaptada de Godoi, Mastella e Uchôa (2018).

Assim, compreendemos que a ASD se aproxima de nosso objeto de pesquisa quando pensa o discurso como categoria analítica do social. Não somente por isso, mas porque é um movimento metodológico que analisa o discurso em seu nível coletivo. Sabemos que os sujeitos são atravessados por esquemas, ideias e concepções culturais e sociais que são manifestas no discurso. Elegemos, portanto, a ASD como o método desta pesquisa.

\subsection{Técnica de pesquisa}

Antes de mais nada, é preciso anunciar que o momento presente é de profundas mudanças sociais. Um momento que o mundo parou diante da pandemia da COVID-19. Estamos aprendendo a viver esse momento tão confuso, incerto e que requer ainda mais de nossa capacidade criativa. Quando construímos nosso objeto de pesquisa, pensamos em uma pesquisa de campo que pudesse priorizar metodologias e interação social.

Contudo, o momento é de respeito ao isolamento social, à saúde e ao bemestar de todos. Assim, nossas técnicas de pesquisas foram realizadas, valendo-se da perspectiva tecnológica aqui defendida, por meio do ciberespaço. Tanto a aplicação de questionário quanto o grupo de discussão serão mediados por tecnologias. Escolheremos o Google Meet e Google Forms como plataforma tecnológica que 
mediará as técnicas de coleta de dados. Essas plataformas são escolhidas diante da segurança ofertada na sua política de privacidade e também por ter uma variedade de aplicações que podem facilitar o acesso, a gravação e outras questões relacionadas à pesquisa.

Para manter coerência entre os procedimentos metodológicos e o objetivo de pesquisa, escolhemos duas técnicas de pesquisa que dialogam com a ASD e que demonstra potencial de coleta de dados. Primeiro elegemos a aplicação de questionário, com abordagem estruturada, e depois escolhemos o grupo de discussão como técnica de pesquisa.

O questionário, conforme Richardson (2007), é uma técnica importante para a pesquisa qualitativa. As perguntas em um questionário foram fechadas e objetivaram motivar o entrevistado a manifestar um sistema, mais ou menos organizado, de crenças, motivações, sensações e atitudes. A natureza dessa técnica é saber como e por que algo acontece.

No que se refere ao grupo de discussão, Godoi, Mastella e Uchôa (2018) apontam que essa técnica se aproxima do discurso social. O grupo de discussão permite que conflitos ideológicos sociais surjam durante os diálogos. Pretende-se, com essa técnica, a reprodução do discurso ideológico, as marcas do cotidiano e os signos da realidade social. Essa reprodução se dá pelos discursos dos sujeitos sociais.

Para os autores, essa técnica permite a interpretação dos contextos, dos valores, das crenças e das expectativas. Surgem "[...] a projeção de seus desejos, resistências e temores, conscientes e inconscientes em torno do problema investigado" (GODOI; MASTELLA; UCHÔA, 2018, p. 37). Uma das vantagens dessa técnica é a produção livre do discurso, o que permite uma interação maior entre os participantes e o moderador.

O grupo de discussão chega a um consenso ao final de sua interação. Há trocas, negações e (re)produção de sentidos e das representações cotidianas e sociais. O grupo de discussão é formado pelo pesquisador, que é o mediador, e pelos sujeitos sociais. A função do mediador é provocar um tema e discussão capaz de chegar a um consenso. A duração do grupo de discussão é, geralmente, de duas horas. Para selecionar os participantes do grupo, o pesquisador não pode esquecer o contato dos sujeitos com a realidade a ser pesquisada, suas posições culturais e 
sociais e aqueles sujeitos de discursos que denotem relações relevantes com o objeto de pesquisa (GODOI; MASTELLA; UCHÔA, 2018).

Nesse sentido, propomos realizar entrevistas em profundidade com professores de sociologia, coordenador pedagógico e diretor. Isso porque pretendemos identificar suas visões sobre o aparelhamento digital e como eles lidam com esse fenômeno. Em seguida, propomos o grupo de discussão com a formação de estudantes, pois eles são os sujeitos da pesquisa e podem revelar o discurso social sobre o fenômeno, visto que concebemos o aparelhamento digital a partir das vivências dos estudantes.

\subsection{Análise e sistematização dos dados}

Para analisar os dados obtidos, propomos, mantendo coerência com ASD, a sociohermenêutica. Coelho (2012) nos diz que essa concepção abrange a dimensão mais pragmática da linguagem, bem como dos seus usos sociais. Entende, pois, que o sentido excede o texto. O discurso sendo uma "atividade, prática social e discursiva" (COELHO, 2012, p. 99) é um processo criativo, que tensiona conflitos, mobiliza sentidos.

Pela sociohermenêutica, analisamos o discurso contextualizador em detrimento do sentido individual do discurso. Trata-se de uma contextualização histórica daquele que enuncia, suas redes de sentidos e suas conexões com o mundo social.

\subsection{Fontes de informação}

Foram participantes desta pesquisa os estudantes de terceiro ano do Ensino Médio da escola pública estadual que denominaremos Escola Florestan Fernandes. Esses participantes ingressaram no grupo de discussão, que chamamos de rodas de conversa. Realizamos duas rodas de conversas nos dias 11 e 17 de novembro de 2020.

Além dos estudantes, entendemos que foi importante a participação dos professores de Sociologia, coordenação pedagógica e direção da escola. Essa escolha se dá em virtude de que são atores sociais dentro da instituição que podem 
revelar outras perspectivas do fenômeno a ser investigado. Esses participantes integraram a pesquisa por meio da aplicação de questionários. Não pretendemos, contudo, centrar os dados nos discursos do corpo docente, mas entendê-los de modo suplementar.

4.8 Critérios de inclusão e exclusão

Critério de inclusão: estudantes matriculados na escola desde o primeiro ano do Ensino Médio, pelo menos; estudantes que façam uso diário de aparelhos digitais; estudantes que tenham cadastro em pelo menos uma rede social.

Critério de exclusão: estudantes matriculados na Educação de Jovens e Adultos; estudantes que não desejam participar da pesquisa voluntariamente. 


\section{ANÁLISE E DISCUSSÃO DOS DADOS}

A presente seção da pesquisa pretende, com a utilização dos materiais produzidos em campo, construir a análise crítica da discussão. Para facilitar a compreensão de cada objetivo, foram divididas as categorias centrais de investigação do trabalho e em cada uma foi delimitado, teoricamente, com um sociólogo mais influente dentro do campo para embasamento e discussão.

Optamos por trazer os discursos dos estudantes em quadros, para melhor compreensão da análise dos dados. Em cada quadro, que é apresentado durante a análise, trazemos as unidades de análise, que serviram de sustentação para análise. Destacamos essas unidades nos discursos utilizando como critério os termos que mais sobressaem das narrativas e que possibilitam uma interpretação mais rigorosa e aprofundada. São termos que estão ligados às categorias de análise e que são desdobrados, de modo interrelacional, em um exercício sociológico crítico de análise.

A partir da identificação das unidades de análise, conseguimos pensar em que campo o discurso é atravessado, disputado e construído socialmente. Para Bourdieu (2012) passa a ser a representação de um espaço simbólico. Nesse campo, agentes - que são sujeitos e são determinados e autodeterminados - acabam, em suas lutas, determinando as formas simbólicas que estruturam o campo. Após a percepção dos campos, tecemos uma análise que se volta para as categorias de investigação deste trabalho.

\subsection{Apresentação do campo da pesquisa}

A Escola Florestan Fernandes ${ }^{8}$, situada no município de Arcoverde- PE, foi construída no ano de 1947. Foi considerada a escola piloto daquela época, onde acolhia e irradiava para outros setores instruções da Secretaria de Educação e Cultura de Pernambuco. Em 1970 tornou-se Ginásio, com a finalidade de ministrar o Ensino Médio de $1^{\circ}$ Ciclo Secundário, que passou a funcionar no turno noturno, sendo, posteriormente, elevada à categoria de $1^{\circ}$ e $2^{\circ}$ graus. No ano de 1974 , com a

\footnotetext{
${ }^{8}$ Optamos por representar a escola do campo de pesquisa a partir de outra nomeação, visando proteger a identificação dos sujeitos participantes. Assim, chamaremos, neste trabalho, o campo de pesquisa de Escola Florestan Fernandes.
} 
reestruturação do ensino pela Secretaria de Educação, foi substituído o então Grupo Escolar, passando a ser apenas uma Entidade, com Ensino de $1^{\circ}$ e $2^{\circ}$ graus, onde este eixo educacional encontra-se funcionando até os dias atuais. Com a aprovação da Lei de Diretrizes e Bases Nacionais 9394/96, a Escola passa a ter cadastro no Ministério de Educação e Cultura - com Associação de Pais e Mestres, Grêmio Estudantil e Conselho Escolar que dão suporte a Unidade Executora da Escola.

A Escola possui alunos com média de 11 a 50 anos de idade, com 1220 alunos matriculados, estes frequentando assiduamente a escola, nos dias de segunda-feira à sexta-feira. A escola oferece o ensino nas modalidades Ensino Fundamental Anos Finais, Ensino Médio e Ensino Médio de Jovens e Adultos. Por estar situada em uma área privilegiada da cidade e também por ofertar a modalidade regular de Ensino Médio no turno noturno, atende a todos os bairros do Município e também a uma parte da zona rural.

O perfil socioeconômico é bem diversificado, mas a maior parte dos estudantes encontram-se inseridos na renda mínima, onde dependem do Programa Federal Bolsa Família. Verifica-se que do número de 1220 alunos, $80 \%$ são localizados na zona urbana e $20 \%$ vêm da zona rural. Destacamos que todo o material de apoio ao estudante, como cadernos, livros, merenda, fardamento e outros, são subsidiados pelo Governo Estadual e Federal.

A Escola Florestan Fernandes é uma entidade de inclusão, onde atende alunos portadores de necessidades especiais em sala regular e também possui uma sala de Atendimento Educacional Especializado (AEE). Apresenta estrutura física adequada, em boas condições, com mobiliário conservado e em boas condições de uso.

A Escola dispõe de Pessoal Educativo, distribuído em: 01 Gestor, um Gestor Adjunto, 03 Educadores de Apoio, 03 Técnicos Educacionais, 01 Secretário, 01 Bibliotecário, 04 Merendeiras, 04 Auxiliares de Serviços Gerais e 02 Porteiros. Sobre a estrutura e Funcionamento, a instituição possui 12 salas de aula, 01 sala de professores, 01 sala biblioteca, 01 sala secretaria, 01 diretoria, 01 laboratório de informática, 01 depósito de merenda, 01 cozinha, 01 pátio coberto/refeitório, 11 sanitários femininos, 11 sanitário masculinos, 01 sanitário para professores e 01 quadra esportiva.

As turmas em funcionamento estão assim distribuídas: 04 turmas do $6^{\circ}$ ano do Ensino Fundamental, 05 turmas do $7^{\circ}$ ano Ensino Fundamental, 4 turmas do $8^{\circ}$ ano Ensino Fundamental, 5 turmas do $9^{\circ}$ ano Ensino Fundamental, 05 turmas do $1^{\circ}$ Ensino 
Médio, 04 turmas do $2^{\circ}$ Ensino Médio, 4 turmas do $3^{\circ}$ Ensino Médio, 01 turma do $3^{\circ}$ módulo do Ensino Fundamental, 01 turma do $5^{\circ}$ módulo do Ensino Fundamental, 01 turma do $7^{\circ}$ módulo do Ensino Fundamental, 01 turma do $8^{\circ}$ módulo do Ensino Fundamental, 02 turmas do $1^{\circ}$ Módulo do Ensino Médio de Jovens e Adultos, 01 turma do $2^{\circ}$ Módulo do Ensino Médio de Jovens e Adultos, 01 turma do $3^{\circ}$ Módulo do Ensino Médio Ensino Médio de Jovens e Adultos, 01 turma do Projeto Travessia Ensino Médio e 02 turmas de Atendimento Educacional Especializado (AEE).

A Escola Florestan Fernandes tem como função social principal respeitar e valorizar as experiências de vida dos estudantes e de suas famílias. Quanto à educação, a escola tem como missão a construção de justiça, fraternidade e democracia, com conceitos humanitários para formar estudantes críticos politizados, com visão ampla de mundo, capazes de superar preconceitos sociais e que atuem na sociedade e usufruam de direitos e deveres presentes na Constituição Federal do Brasil de 1988 e na Lei de Diretrizes e Bases Nacional da Educação do Brasil, Lei 9394/96 que rege a educação no Brasil. A instituição de ensino também oferece aos estudantes as garantias nas leis Antibulling $n^{\circ} 13.995$ de dezembro de 2009, Lei Afroindígena $\mathrm{n}^{\circ}$ 11.645, como também no Estatuto da Criança e do Adolescente.

A Escola Florestan Fernandes orienta as suas ações pedagógicas a partir da Lei 9.394/96, principalmente com a difusão das ideias de Piaget, Vigotsky e Wallon, onde numa perspectiva sócio-histórica essas teorias buscam uma aproximação com modernas correntes do ensino que consideram a forma de atuação sobre o homem e o mundo, ou seja, como processo de interação verbal, que constitui a sua realidade fundamental.

Os objetivos principais da instituição, quanto aos níveis de ensino são: desenvolver as competências de aprendizagem, postura pesquisadora, autoestima, valorização do lugar como espaço vivido e apropriado; desenvolver as habilidades e competências a aprendizagem e formação para atuar no mercado de trabalho; desenvolver competências e habilidades de aprendizagens, capazes de formar cidadãos críticos e conscientes dos seus direito a e deveres, com capacidade de ingressar no mercado de trabalho e dar continuidade aos estudos.

A proposta de educação da Escola Florestan tem ênfase em três aspectos importantes na questão da metodologia de ensino: pedagogia de análise crítica dos conteúdos, como processo de interação verbal; prática-teoria-prática e participação coletiva. Dessa forma, a escola acredita que a educação não é obra apenas da 
inteligência e do pensamento, é também da afetividade, do sentimento. E que esta combinação precisa estar tanto no ato de educar, como no de ser educado e deve ser pilar da relação educador-educando, sustentado pelo companheirismo e pelo respeito no sentido profundo e libertador da palavra.

Quanto à avaliação, a instituição pesquisada entende o ato como um processo contínuo e pontual, contextualizado por toda a comunidade escolar, com realização de práticas avaliativas a partir de avaliações diagnósticas participativa, mensurativa, levando em consideração o aluno como um todo, com sua bagagem cultural e as diferenças individuais. A orientação metodológica das avaliações norteia o trabalho do professor em detrimento as competências e habilidades desenvolvidas pelos estudantes.

5.2 Os sujeitos participantes e as questões éticas da pesquisa

Lembramos que o cenário das pesquisas empíricas em 2020 sofreu grandes reverses dada a pandemia do novo coronavírus. Conseguimos identificar, pelos critérios de inclusão, 22 estudantes. Quando verificamos os critérios de exclusão, chegamos a um quantitativo de 13 estudantes. Sabendo das dificuldades de acesso à internet, bem como dos estados psicológicos que tivemos que enfrentar dada as situações de morte e doença neste ano, realizamos 2 rodas de conversa com a participação dos sujeitos participantes. As rodas de conversa tinham duração de até 30 minutos e foram gravadas e armazenadas pela pesquisadora. Utilizamos o Google Meet como ferramenta de suporte para as rodas de conversa.

Os sujeitos participantes assinaram Termo de Consentimento Livre e Esclarecido, bem como o Termo de Assentimento Livre e Esclarecido, quando foi o caso. Os termos foram enviados via correio eletrônico.

Em relação ao corpo docente que respondeu questionário por meio do Google Forms, também assinaram Termo de Consentimento Livre e Esclarecido. Identificamos os professores que lecionavam sociologia e enviamos o questionário eletrônico. Participaram dessa etapa três professores. Enviamos para sete professores, mas obtivemos a participação de apenas três.

De início temos os dados básicos dos entrevistados que, por questões éticas da pesquisa, utilizamos códigos para identificar o(a) estudante. Assim, temos: 


\section{Quadro 2 - Sujeitos Participantes da Pesquisa}

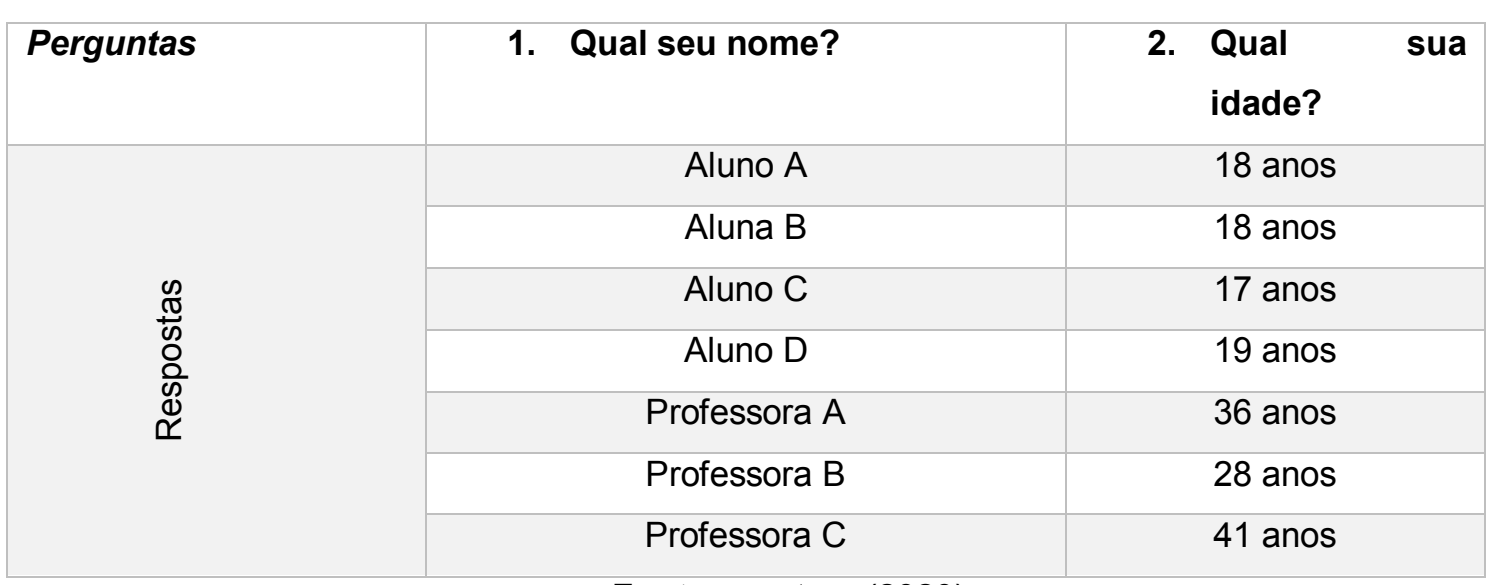

Fonte: a autora (2020).

5.3 Os cenários de aprendizagem: aparelhamento digital e cibercultura no contexto de investigação

Com o advento das novas tecnologias, tem-se uma modificação cada vez maior das formas de interação entre os indivíduos. E é através dessa nova perspectiva que se deve desenvolver cada vez mais o entendimento dessas novas tecnologias e ferramentas de interação social para melhor compreendemos o social em sua complexidade.

Abaixo segue o quadro que servirá de roteiro, neste primeiro momento, para nossa análise: 


\section{Quadro 3 - Um Bom Professor}

\begin{tabular}{|c|c|c|c|}
\hline SUJEITO & DISCURSO & $\begin{array}{l}\text { UNIDADE(S) DE } \\
\text { ANÁLISE }\end{array}$ & CAMPO \\
\hline Aluno A & $\begin{array}{l}\text { "É aquele que não... já foi falado...é aquele } \\
\text { que não se prende só no assunto e sim } \\
\text { interage além com o aluno" (RODA DE } \\
\text { CONVERSA, 14/11/2020). }\end{array}$ & Interação & \\
\hline Aluna B & $\begin{array}{l}\text { Acho que aquele professor que não só vê } \\
\text { que o aluno não... tipo ele tá } \\
\text { desinteressado, ele vai lá e tenta fazer com } \\
\text { que o aluno se interesse, corre atrás do } \\
\text { aluno quando vê que o aluno tá se } \\
\text { perdendo no meio do caminho, faz } \\
\text { coisas variadas, diferentes, aí faz aulas } \\
\text { divertidas também. Mas também tem na } \\
\text { parte em que ele faz aquela aula mais fria. } \\
\text { Tipo aquele professor que interage com } \\
\text { todos os aluno, como o aluno A disse, que } \\
\text { tenta buscar sempre o melhor, não só pra } \\
\text { turma, não só pra o aluno, mas pra ele } \\
\text { também, que ele se sinta bem dando } \\
\text { aquela aula" (RODA DE CONVERSA, } \\
\text { 14/11/2020). }\end{array}$ & $\begin{array}{l}\text { Interesse } \\
\text { Desvio } \\
\text { Interação }\end{array}$ & \\
\hline Aluno C & $\begin{array}{l}\text { "Bom, pra mim é... eu acredito que o } \\
\text { professor não tenha só que saber o } \\
\text { assunto, ele tem que saber é... como eu } \\
\text { posso falar...ele tem que saber passar o } \\
\text { assunto pra pessoa, tentar fazer com que } \\
\text { os alunos absorvam o conteúdo, } \\
\text { entendeu? Porque eu acho que não } \\
\text { adianta a gente... não adianta ele saber o } \\
\text { assunto, obviamente ele vai saber por ser } \\
\text { professor, mas o importante é repassar } \\
\text { entendeu? Eu acredito nisso" (RODA DE } \\
\text { CONVERSA, 14/11/2020). }\end{array}$ & $\begin{array}{l}\text { Conhecer } \\
\text { Saber } \\
\text { Transmissão } \\
\text { Produção de } \\
\text { conhecimento } \\
\text { Aprendizagem }\end{array}$ & 0 \\
\hline Aluno D & $\begin{array}{l}\text { "É uma das primeiras coisas que eu falei no } \\
\text { começo, professora é... aquele professor } \\
\text { que é amigo do aluno que... Professor } \\
\text { praticamente é a família da gente durante } \\
\text { o período da nossa vida, então...o } \\
\text { professor além de ser professor, ele tá ali } \\
\text { como nosso amigo, conselheiro também. } \\
\text { Que eu vejo muito professor que só chega } \\
\text { pra dá aula, só conhece o aluno ali em } \\
\text { sala de aula e pronto, depois dali não } \\
\text { existe mais o aluno pra ele, não existe mais } \\
\text { nada, passa na rua, finge que nem } \\
\text { conhece. Então eu acho que seria esse um } \\
\text { bom professor" (RODA DE CONVERSA, } \\
\text { 14/11/2020). }\end{array}$ & $\begin{array}{l}\text { Interpessoalidade } \\
\text { Relações sociais } \\
\text { Cotidiano }\end{array}$ & \\
\hline
\end{tabular}

Fonte: A autora (2020). 
Para podermos construir o conhecimento, iniciemos discutindo as ideias de cibercultura e os diferentes espações reais ou virtuais. $E$ através disso vamos compreender a relação desse novo ambiente com suas regras e os processos de aprendizagem. Deste modo, um dos principais teóricos dentro dessa perspectiva é Pierre Lévy (1998), que vem a definir e desenvolver várias concepções e significados dentro deste meio tecnológico. Na discussão dos processos de interação entre os atores sociais, questionamos: em que lugar se dão essas interações entre os seres?

Quando observamos as relações entre sujeitos, entendemos que esses acontecimentos pressupõem um local, um ambiente e um espaço no tempo, uma vez que determinação de locais e de acontecimentos partem não só do espaço físico que se ocupa, mas também do espaço temporal que as interações ocorrem. Com isso emerge o pensamento do ambiente cibernético ser um local ou não.

Mas o pensamento sobre o ambiente esbarra na definição de virtual; está sendo uma versão, uma atualização da realidade, porém ao mesmo tempo, não podendo ser definida como uma realidade alterada. Ou seja, o virtual seria uma espécie de realidade atualizada, com novas formas e questões, porém, não seria uma realidade tal quanto conceituamos, sendo uma representação de algo que existe concretamente. São informações abstratas que, lançadas dentro de um ambiente, se tornam caricaturas das figuras ou representações do que seriam na realidade. Sendo assim, já podemos abordar o virtual como uma representação da realidade, que por ser somente um espelho não se define inversamente como realidade (COSTA; SOUZA, 2005).

Chegamos então, no ciberespaço. Ele pode ser apresentado como a interação ou comunicação entre os diferentes tipos de sujeitos conectados dentro deste espaço. Portanto, o virtual e o ciberespaço têm relações mútuas, todavia, não se definem um no outro, ou seja, o virtual seria o espaço ou a recriação da realidade, e o ciberespaço seria as comunicações ou interações entre os indivíduos dentro destes ambientes.

Assim responde-se à pergunta inicial: as interações ou ciberespaço se dão em um espaço, porém este sendo uma abstração da concepção de espaço (LÉVY, 2011). Quando se coloca a definição de ciberespaço, não a joga direto no lócus de pura comunicação, mas também se anexa a ela todo o mar de informações carregado nos atos de ir e vir do conhecimento. 
Assim, a base para firmar as concepções de cibercultura - pois esta é a denominação de todos os vícios, os modos e formas, as práticas de modos de pensamento agrupados dentro do desenvolvimento e crescimento do ciberespaço, ou seja, enquanto um - é a comunicação. Nela temos a informação sendo transitada de um local para outro; a cibercultura são as atitudes, as práticas vinculadas a essas informações os vícios carregados dentro de cada troca de conhecimentos (SIMÕES, 2009).

Para se chegar a esse pressuposto, seguiu-se um raciocínio linear, partindo de simples suposições teóricas. A língua oral, de início, era como se dava a passagem de informações; a escrita seria a ampliação deste aspecto, pois desta forma o sujeito responsável pelo pensamento se distancia do conhecimento por ele apresentado, já que o peso de validação não fica mais no sujeito e sim na informação passada. Sendo assim, os aspectos e caracteres escritos se sobrepõem em importância e validade científica sobre os caracteres orais. A escrita passa a ser uma virtualização do pensamento, da memória. Assim temos como exemplo a enciclopédia, um amontoado de informações antes oralizados, agora completas em verdades e justificativas (SIMÕES, 2009; VEIGA-NETO,1999).

Após o processo de escrita, de representação através de caracteres físicos, temos a hipertextualização, na qual o conhecimento não se baseia somente nos aspectos de um único sujeito e sim do coletivo. As informações são validadas pelo todo, pelo grupo pensante. Com isso chega a construção da inteligência coletiva, que nela são baseadas as premissas do ciberespaço e cibercultura (VEIGA-NETO, 2009).

Com a democratização dos computadores, vemos cada vez mais uma introdução de sujeitos nesse ambiente e dessa forma os aspectos de cibercultura se modificam, pois as informações existentes se agregam em novas perspectivas de vida e de se relacionar com o outro sujeito. A hipertextualização torna-se um conjunto de informações não mais linear, permitindo assim que o sujeito transite entre um e tantos outros lugares, intenções e posições. O texto passa a ser o principal meio que lhe permite linkar?

Assim cada indivíduo apresenta uma visão ou concepção sobre o texto principal, já que cada um envereda de acordo com assuntos, temas os quais ache mais importantes ou atrativos. Constrói para cada um, uma verdade sobre a realidade

\footnotetext{
${ }^{9}$ Neologismo que vem do termo em inglês, link. Podemos entender como sendo ligação.
} 
e assim temos o ciberespaço com a cibercultura de cada indivíduo interagindo e se alterando. Pode-se pensar, no entanto, que um texto construído, seja através de caneta e papel, impresso ou até mesmo digitado em computador, se assemelha entre suas variações. Pois não são somente um amontoado de informações de forma linear, seguindo um raciocínio de um ponto "A" para um ponto " $B$ ".

O que os torna diferentes são as ferramentas que os permitem ser modificados e nos modificar: um texto em papel não possui a mesma maleabilidade que um produzido na internet, já que este último permite uma mescla maior de informação, pelo simples fato de reprodução e supressão de informações de modo mais simples - o ato de copiar e colar. E essa ferramenta, que através de sua utilização altera nossa forma de entender o texto e de nos relacionar com ele, torna-se assim um hipertexto (VEIGA-NETO, 2009).

Para se compreender de modo simples, pensemos no processo de plágio de informações, que com o desenvolver de novas formas de escrita ou de interação com os textos se tornou uma prática mais fácil de se realizar e, por contraponto, de mesma medida se tornou mais rígida sua verificação e punição. Ou seja, o simples ato de se modificar a interação do sujeito para com o texto, fez com que posturas e ações fossem tomadas frente a essa ação.

Com os novos horizontes trazidos pela internet, e se valendo de uma representação abstrata do funcionamento da mente humana, surgem novos modos de se aprender. Através dos aspectos de hipertextos, temos uma nova forma de cultura, e essa vem apresentando alguns pilares para sua formação. Os grupos da sociedade que visam novas tecnologia fazem surgir a cultura tecnocrática. Nela os grupos que primam pelo desenvolvimento e inovação de novas ferramentas para produção e alteração de conteúdo dentro da internet, acabam consolidando a ideia de que o progresso humano se dá através da tecnologia (CASTELLS, 1999).

Além de traçar as bases de sustentação e desenvolvimento da internet, do ciberespaço e da cibercultura, precisamos atentar que, como discutido inicialmente, a interação entre indivíduo e máquina/aparelhos digitais, no caso aqui computadores ou, atualmente, aparelhos de telecomunicação móvel, gera uma diferenciação dos campos de interação, passando de um local para um não-lugar. E como toda relação entre sujeitos depende de um local no espaço-tempo, temos a mudança das percepções de tempo, este passando de maneira demasiadamente rápida, pois tem 
relação direta com a transmissão de informações, e estas sendo de modo contínuo e acelerado, o tempo segue o curso de mesma forma.

Mas o ato de compreender isso não é somente de modo a se ter mais informações sobre a internet, e sim conseguir empregar conhecimentos e concepções dentro deste meio, compreendendo seus regimentos e formas. $O$ fato de perceber $o$ acelerado passar do tempo no meio virtual, nos leva a entender o desfasamento das informações que a cada hora são lançadas dentro deste. Lembrando que os indivíduos que se fazem presentes nesse meio são bombardeados diretamente por dados e informações com vistas a consumirem cada vez mais.

A comunicação como principal ferramenta que cria e molda as ideias dentro deste campo - que é a internet - é de extrema importância, pois com ela as capacidades dos sujeitos que compõem a sociedade são lançadas para o ambiente, conjuntamente com suas culturas e práticas. Ao mesmo tempo que as lançam, os sujeitos as modificam, já que o desenvolvimento permitiu a criação dos computadores e, por conseguinte, da internet, e esta altera as concepções e formas de ver o mundo que o sujeito inicialmente possuía.

E assim, os grupos culturais alteram a cibercultura e por ela são alterados, conforme utilizam as ferramentas que por elas são aprimoradas. O aparelho digital deixa de ser uma coisa única e passa a ser o todo, sem ser possível delimitá-lo, e o sujeito que o utiliza como extensão de seu corpo e pensamento, se une nessa egrégora, sendo um coletivo de ideias e ações. Assim,

[...] o programa no qual alguém edita um determinado texto, está fisicamente
gravado no HD do computador, e quem o digita está sempre saindo do
totalmente virtual para o físico, salvando o documento para não perder as
informações no limbo da virtualidade. E ainda assim, o texto em estado virtual
antes de ser gravado no espaço físico, o "lugar" Hard Disck, tem o suporte
físico da memória, podendo até mesmo ser, com alguma sorte, recuperado
da inexistência concreta. O chat, a câmera de vídeo conferência, ou mesmo
os jogos e programas de realidade virtual, são mediações físicas, numa
interface de homem concreto - máquina concreta - homem concreto. Virtual
por Virtual, a realidade é sempre uma virtualização do que está gravado em
nossos cérebros (SOUZA; COSTA, 2005).

Com a ideia de consciência coletiva vem também a ideia de que a internet, como meio de difusão de informações, democratiza a informação, pois, uma vez que informação está ali presente, todos podem ter acesso a ela. Com isso, deduzimos alguns aspectos sociológicos interessantes que resultam disso: 
a) os sujeitos que não adentraram nesse ambiente tecnológico estariam julgados e lançados à margem pela sociedade que utiliza desse ambiente, denominados analfabytes (LIMA, 2009) - sendo uma espécie de mescla de ações que vem a produzir desconforto nos não utilitários.

b) Lembrando que nenhum indivíduo está completamente imerso e participativo, já que a internet é ampla e multifacetada, por seguinte têm os que dela fazem utilização, sendo bem aceitos e preferidos, e por último, dentro do grupo dos que da internet utilizam, há aqueles que se perdem em meio a tanta informação, que não conseguem se achar ou firmar-se e são levados a esmo por toda a imensidão de informações ali presentes (VEIGANETO, 2009; LÉVY, 2001).

c) Com isso temos dois grades focos: um que determina que o virtual ao ser uma representação da realidade em sociedade, também repetiria as segregações, tornando um discurso ou ciberespaço superior ou detentor de maior poder em comparação com outros (SIMÕES, 2009; CASTELLS, 1999). E o de igualdade como já citado, uma vez que o conhecimento pertence a todos, não há a distinção de maior ou menor saber, quando dentro da internet (SIMÕES, 2009; LÉVY, 2001).

Ao contextualizar essa análise com a educação atualmente, temos que o ambiente em que os sujeitos se inserem está em plena modificação, sendo representações mais próximas dos ambientes e comunidades que eles estão inseridos ou que gostariam de estar. Estes ambientes, uma vez o sujeito inserido no espaço virtual, apresentam o tempo transcorrendo de modo diferente, pois com mais e mais bombardeamento de informações, a percepção dessas informações e o passar de uma para outra é alterada. A construção de informações deixa de ser de partida de um único indivíduo sendo agora de um coletivo pensante. Logo, o indivíduo gera conhecimento através das relações com todos, e é esta informação que voga nos embates de verificação da verdade.

As ferramentas digitais, como computadores e aparelhos telefônicos, geram modificações no sujeito, seja na forma de absorver informações, no modo de interagir com outros sujeitos ou ambiente ao seu redor. Com isso, geram mais mudanças nessas ferramentas, gerando aparelhos, constantemente construindo um ciclo de mutações. Nestes processos de ter acesso a toda uma gama de informações, alguns se guiam e mantem firmes, enquanto outros são levados pela correnteza e se perdem 
em meio a tanto conhecimento, dado e informação, não sabendo, assim, como se reerguer.

Abaixo lançamos o quadro que trará o segundo momento de nossa discussão:

\section{Quadro 4 - Uso das redes sociais}

\begin{tabular}{|c|c|c|c|}
\hline SUJEITO & DISCURSO & $\begin{array}{l}\text { UNIDADE(S) DE } \\
\text { ANÁLISE }\end{array}$ & CAMPO \\
\hline Aluno A & $\begin{array}{l}\text { "A rede social tá sempre presente no meu } \\
\text { dia a dia. Porém, ao usar tem que ter pelo } \\
\text { menos uma moderação, porque nem tudo } \\
\text { que a gente vê na internet deve acreditar, } \\
\text { deve compartilhar, tem que ter sempre uma } \\
\text { atenção" (RODA DE CONVERSA, } \\
\text { 14/11/2020). }\end{array}$ & $\begin{array}{l}\text { Cotidiano } \\
\text { Uso } \\
\text { Consciência }\end{array}$ & \\
\hline Aluna B & $\begin{array}{l}\text { "A tecnologia é muito presente atualmente na } \\
\text { minha vida. Digamos que completamente, eu } \\
\text { uso a tecnologia pra tudo, entre aspas, mas } \\
\text { às vezes eu acho que ela influencia muito a } \\
\text { gente fazer coisas boas e coisa ruins também. } \\
\text { Então às vezes a gente tá com os amigos e } \\
\text { esquece do mundo e fica só no celular e tal. } \\
\text { É tanto que as vezes eu crio muitos critérios } \\
\text { de tipo... eu vou sair com meus amigos, ou eu } \\
\text { deixo o celular em casa, ou eu levo o celular e } \\
\text { não utilizo, eu deixo o celular só pra olhar a } \\
\text { hora essas coisas e tal. Porque a gente se } \\
\text { prende muito nesse meio de tecnologia e } \\
\text { acaba esquecendo de viver a vida aqui fora, } \\
\text { fora das redes sociais, fora de celular, de } \\
\text { internet e tal. E como o aluno A disse, a } \\
\text { internet ela tem suas notícias e tem coisas } \\
\text { que a gente pode usar para o bem, quanto } \\
\text { para o mal. E a gente tem que saber separar } \\
\text { o que de fato é verdadeiro e o que não, o } \\
\text { que de fato nos atinge... e às vezes quando } \\
\text { essas coisas que nos atinge nos faz mal a } \\
\text { gente precisa se desligar um pouco e não } \\
\text { rebater aquilo. E hoje em dia o que mais tem } \\
\text { é discussão, é briga por causa da tecnologia" } \\
\text { (RODA DE CONVERSA, 14/11/2020). }\end{array}$ & $\begin{array}{l}\text { Cotidiano } \\
\text { Presença } \\
\text { Uso } \\
\text { Influência } \\
\text { Realidade } \\
\text { Realidade virtual } \\
\text { Critérios } \\
\text { Aparelhamento } \\
\text { digital } \\
\text { Mediação } \\
\text { conhecimento do } \\
\text { Verdade(s) }\end{array}$ & \\
\hline Aluno C & $\begin{array}{l}\text { "Minha relação... primeiramente que a } \\
\text { senhora sabe que a maioria dos alunos que } \\
\text { estudam à noite a gente trabalha né? E } \\
\text { desde o meu trabalho eu já trabalho no } \\
\text { computador. É...eu acredito que a maioria } \\
\text { das profissões futuras estão sendo } \\
\text { modernizadas pra isso, pra trabalhar cada } \\
\text { vez mais com a tecnologia. E eu posso dizer } \\
\text { que eu passo quase todo o tempo } \\
\text { conectado a ela, porque pela manhã eu } \\
\text { trabalho no computador, como eu já falei, a } \\
\text { tarde é o momento de estudar. Eu estudo } \\
\text { cursinho, também online, e a noite a escola. } \\
\text { Mas aí o cursinho à tarde eu acho melhor que }\end{array}$ & $\begin{array}{l}\text { Trabalho } \\
\text { Profissionalização } \\
\text { Modernidade } \\
\text { Conectado/Online } \\
\text { Real/Virtual }\end{array}$ & \\
\hline
\end{tabular}




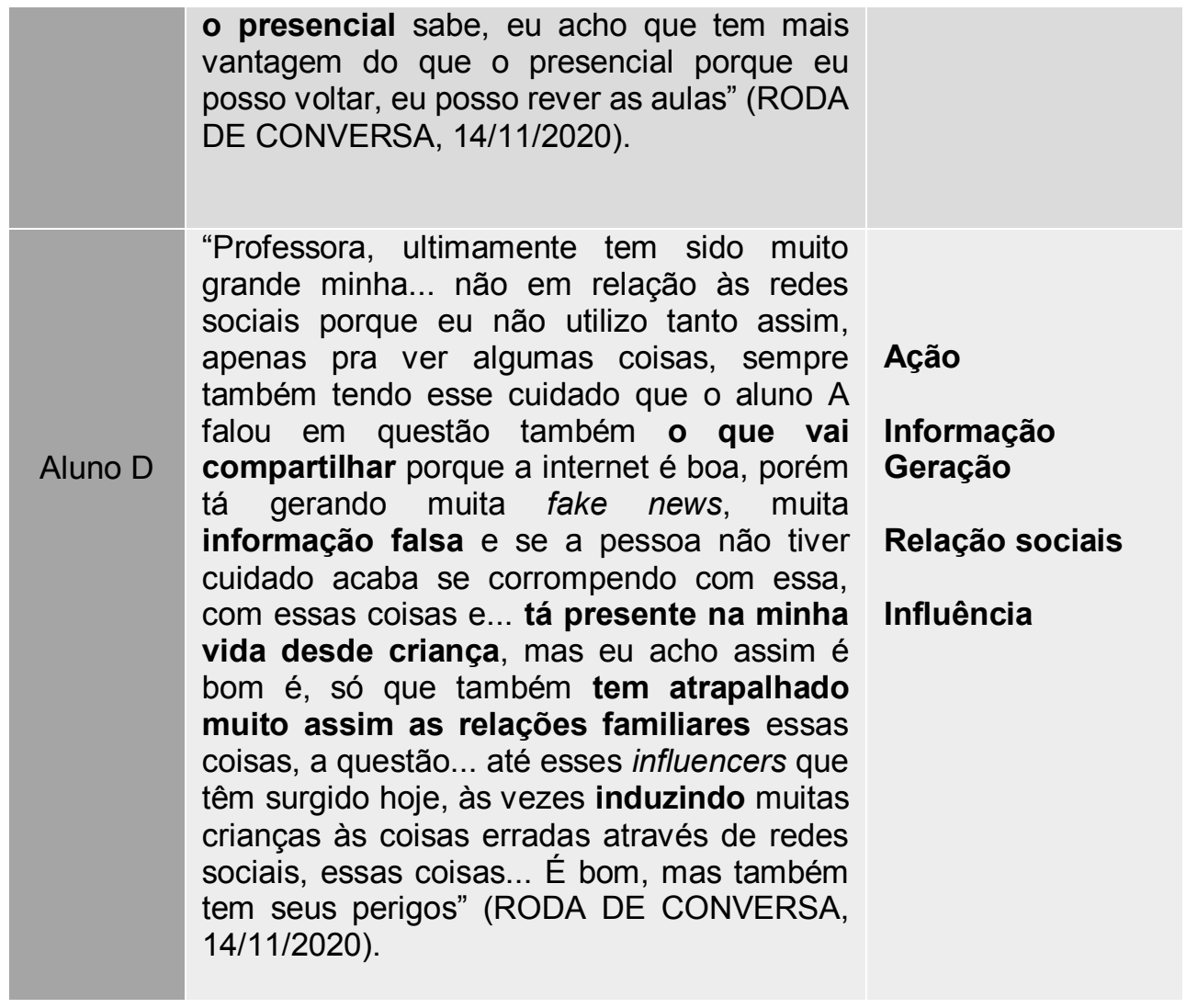

Fonte: A autora (2020).

Nos cenários de aprendizagem, o computador vem não só como uma ferramenta, mas como uma nova formulação de se interagir com o conhecimento. Quando antes se tinha uma forma cognitiva de verificação de novas ideias, com o emprego das novas máquinas e tecnologias, essa conformação precisou ser revista e aperfeiçoada, uma vez que as formas de interação e percepção do ambiente assumem uma nova ótica.

Todos os processos dentro do contexto de educação, especialmente a questão de ensino e aprendizagem, são reformulados, e dessa forma geram impactos em outros campos de atividade humana; produzem técnicas que auxiliam a alteração do conhecimento, assim começa-se a se desenvolver o que é denominado de tecnologias intelectuais (SIMÕES, 2009).

A hipertextualidade do ambiente vem como um resultado das mudanças nos processos de simulação. Isso ocorre seja tanto em relação ao conhecimento como da 
própria noção de ambiente, além das abstrações geradas pelo indivíduo nas suas fases de compreensão do que está sendo apresentado a ele sob a forma de conhecimento. Também ocorre na interação, seja com as ferramentas ou com a própria informação que o sujeito está absorvendo. Por meio da internet, toda essa informação e computação de informação é verificada e explanada, gerado por sua vez, uma grande variação de links, seja com outros textos dentro ou fora do assunto verificado pelo sujeito inicial (SIMÕES, 2009).

Quando observamos a cibercultura, percebemos as relações entre sujeito sendo regidas por representações sociais forjadas nas tecnologias. Dentro destas representações temos concepções, aqui já abordadas, que seria o valor dado a certos discursos, ou seja, algumas posturas e pronunciamentos através do ciberespaço podem ser ou não carregadas de um grau de poder, ou de valor sobre outros (CASTELLS, 1999). Podemos pensar que quando se leva essa discussão para dentro da escola, se traça um paralelo entres as informações que são passadas e verificadas pelo educador indo de encontro com a informação pesquisada pelo educando. Entendemos que essa forma de embate proporcionaria a atualização, constante, do primeiro, pois sem isso há uma proporcional e constante diminuição de importância, valor do conhecimento trazido por este.

Um ponto que pode ser lançado aqui como uma forma de compreender o impacto das novas tecnologias sobre o desenvolvimento intelectual e a concepção de conhecimento pelos sujeitos, é que a produção do conhecimento passa a ser mediada pelos aparelhos digitais. Se a cibercultura e o ciberespaço estão forjando novas formas de subjetividades e novos modos de conhecer e estar no mundo, então é preciso cada vez mais entender o advento do aparelhamento digital.

Desta forma, podem surgir diversas perspectivas. Dentro delas temos os sujeitos que se debruçam sobre essas novas formas de produzir conhecimento mediado pela tecnologia, delegando para elas as funções pensantes. Ou seja, o computador ou a máquina a qual esteja utilizando passa a processar os principais pensamentos contábeis e cognitivos. De modo inverso, outros indivíduos utilizam destes aparelhos apenas como um apoio ou mesmo uma ferramenta para compreender questões iniciadas em suas inquietações. Portanto, sendo nesse caso uma extensão que funciona concomitantemente com o próprio indivíduo. Enquanto a máquina calcula, reconta a informação, o sujeito repensa sua usabilidade, seus diversos enveredamentos dentro dos construtos sociais. 
Com mesmo peso, temos o emprego da memória e do armazenamento de informação repassados para a máquina, para os seus próprios suportes, os HDs. Graças a isso um número maior de informações é captado e verificado por um número também cada vez maior de sujeitos, e com isso temos a perspectiva dos indivíduos que se perdem nesse mar de informações ou que repassam a suas capacidades físicas de armazenamento de conhecimento para uma memória não mais abstrata e sim física, um objeto.

Mais profundamente nos processos educacionais, o enfoque se altera. Enquanto antes da disseminação da internet dentro das diversas classes e grupos, o papel da escola era principalmente o de difundir o conhecimento, ou seja, repassar para o maior número de sujeitos a informação que foi disciplinarizada, agora temos esse papel minimamente validado cientificamente. Naquele tempo-espaço presente, essa função com as novas tecnologias foi repassada para a internet e está cada vez mais rápida e diversa nesse emprego.

A escola tem por necessidade passar por uma reformulação, se desejar e pretender agora não a transmitir conteúdo, mas ensinar a aprender. Dito de outro modo: aprender a pensar, a mostrar para o indivíduo o que e como utilizar aquele conhecimento, informação absorvida, pois o sujeito agora já chega na escola com a informação em mãos e com fácil acesso a esta. Este processo de analisar a informação e saber o que fazer com ela é uma construção de abstração que vai além do simples memorizar informação, possibilitando um paralelo entre o sujeito e o aparelho que este utiliza.

Para o educador agora cabe a função de ensinar ao educando o processo máximo de abstração da informação, a sua aplicação, ou seja, a ferramentização ou instrumentalização da informação. Com isso também se torna, o professor, um ser incentivador da comunicação coletiva, o pensar não é mais construído, constituído por um único sujeito e sim pelo grupo (LIMA, 2009; ALMEIDA, 2013).

Como uma grande cadeia, pode-se pensar no processo de formação pedagógica, que passa a se concentrar nos atos de ensinar a aprender. O que antes tinha como base, na formação de professores, o ato de ensinar a estes a ensinar, como, quando e quais ferramentas utilizar para passar a informação, agora, com a reviravolta causada pela relação com o ambiente virtual, isso muda sobremaneira. Concentra-se em outro foco, outro campo: agora precisa ser observado o ato de ensinar o educador e passar a estas ferramentas que possibilitem incutir no educando 
o ato de apreender a informação e abstrai-la, denominada assim de matética (LIMA, 2009; PAPERT, 1994; RAMAL, 2007).

Com isso temos a mudança de paradigmas educacionais. Nessa reformulação do processo de ensinar, a escola agora cabe a função de ensinar a pensar o sujeito que agora traz, mais forte que antes, o conhecimento de sua vivência, de seus gostos, gerando para a educação um peso a mais, já que esta não vê mais o estudante como um mero depósito de conhecimento; ele mesmo tem em si e a seu alcance informações das mais variadas.

O educador agora tem que exercitar mais ainda os pormenores filosóficos do debate; o conhecimento agora é construído de acordo com a sua utilização e aprimoramento, conforme o embate de informações e o paralelo do que já sabe com o complemento que talvez ainda não tenha, o estudante, abstraído. Afirma Lima (2009, p. 18):

\begin{abstract}
Nada de entupir simplesmente os alunos de conteúdo, sem que dê aos mesmos a oportunidade de refletir, de digerir essa massa de informações multidisciplinares, de aplicá-las em seu cotidiano. Entende ainda que, num mundo totalmente interligado, globalizado e multidiversificado (além de sustentado por uma inteligência coletiva) uma ação educativa individualista é um terrível contrassenso. Toda a pedagogia da rede digital tem sido grandemente influenciada por teorias de aprendizagem que privilegiam ambientes educacionais interativos, com elevado grau de participação do aluno no processo de construção do próprio saber.
\end{abstract}

A educação e os processos de ensino necessitam de grande adaptação nos novos cenários de aprendizagem, principalmente quando a sociedade na qual se insere o sujeito passa por diversas modificações, e esta tem necessidade de atrair e se adaptar ao público-alvo de ensino.

As configurações do professor frente a um novo público, novas solicitações, novas perspectivas sobre o ensinar, com novas tecnologias e os novos espaços passam a ser desbravados e com eles novas formas de absorção de informação em suas novas velocidades. O aparelhamento digital do estudante cria janelas de saber que fazem com que o professor tenha que se refazer, mudar suas formas e concepções sobre o ato de ensinar, visto que os sujeitos aparelhados digitalmente veem no indivíduo humano uma nova figura: não o que passa a informação, mas o que motiva a conseguir novas informações a buscar.

O sujeito e sua relação com os aparelhos digitais e as redes sociais, o mar de informações e como ele lida com essa realidade, como ele desbrava, ou se perde dentro deste vasto campo podem ser percebidos nos discursos dos estudantes que 
trouxemos até aqui. São realidades outras que precisam ser encaradas na pósmodernidade.

5.4 Formação de novas subjetividades na escola no contexto da pós-modernidade líquida

O tempo-espaço que os sujeitos ocupam e as relações entre os sujeitos têm um grande peso em uma análise sociológica crítica, ainda mais quando estes são a força-motriz de mudanças e, ao mesmo tempo, são modificados por essa força gerada pela ação deles. Com isso, iniciamos com a ideia de liquidez das coisas e das ideias. Como principal força de alteração das coisas, temos o tempo, que neste caso é o conceito que mais tem força e ímpeto no entendimento dos relacionamentos, bem como lança resquícios de suas influências sobre os processos de ensino e nos moldes de entender o conhecimento (BAUMAN, 2001).

Abaixo apresentamos os discursos iniciais que estruturam esse pensamento, que será desenvolvido no decorrer do texto:

\section{Quadro 5 - As redes sociais e seus usos}

\begin{tabular}{|c|c|c|c|}
\hline SUJEITO & DISCURSO & $\begin{array}{l}\text { UNIDADE(S) DE } \\
\text { ANÁLISE }\end{array}$ & CAMPO \\
\hline Aluno A & $\begin{array}{l}\text { "Eu uso mais o Instagram. Porque lá a pessoa } \\
\text { pode acompanhar a vida dos famoso e tal, } \\
\text { essas coisinhas assim" (RODA DE } \\
\text { CONVERSA, 14/11/2020). }\end{array}$ & Rotina social & \\
\hline Aluna B & $\begin{array}{l}\text { "Eu uso muito o WhatsApp e o Instagram, mas } \\
\text { entre os dois eu acho que eu uso muito o } \\
\text { WhatsApp porque eu me comunico mais } \\
\text { com as pessoas e tal, tipo é... durante o dia } \\
\text { eu uso muito o WhatsApp pra me comunicar } \\
\text { não só com o pessoal da escola, mas com o } \\
\text { pessoal aqui de casa, que tudo é WhatsApp } \\
\text { com meus amigos também, por aí vai. Então } \\
\text { uso bastante o WhatsApp e trocar mensagem, } \\
\text { mensagem de texto tal" (RODA DE } \\
\text { CONVERSA, 14/11/2020). }\end{array}$ & $\begin{array}{l}\text { Comunicação } \\
\text { Tudo é } \\
\text { Mensagem } \\
\text { Texto }\end{array}$ & \\
\hline Aluno C & $\begin{array}{l}\text { "A rede social que eu mais uso é o WhatsApp, } \\
\text { porque eu acredito que seja mais acessível a } \\
\text { todos né, tanto as pessoas mais velha quanto } \\
\text { as mais novas. É... e acho que é onde tem o } \\
\text { maior público que eu conheço, tem a maior } \\
\text { quantidade de pessoas que eu conheço" } \\
\text { (RODA DE CONVERSA, 14/11/2020). }\end{array}$ & $\begin{array}{l}\text { Acessível } \\
\text { Interação social }\end{array}$ & \\
\hline
\end{tabular}




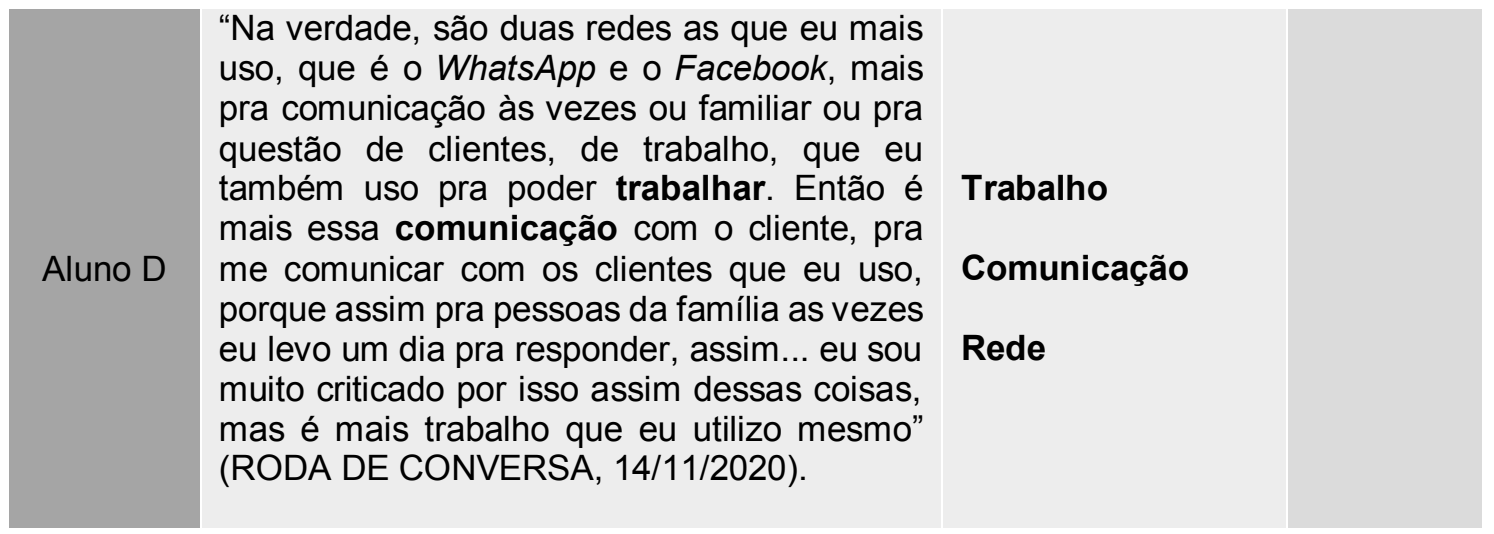

Fonte: A autora (2020).

Iniciar pelos processos que se baseiam o conhecimento é a melhor forma de compreendê-los. Assim, para entendermos a modernidade liquida, iniciemos o que seria definido como líquidos e sólidos, e o que eles têm de relação com as questões sociais. Na química e física, os objetos, quando estudados, são formados por estruturas menores, os átomos, e estes quanto à sua organização, sua disposição, são os responsáveis por sua forma. Quando o objeto apresenta átomos muito próximo e unidos entre si, formando uma verdadeira liga forte entre eles, temos um objeto sólido, um corpo que não se molda, que não sofre alterações, pelo menos não facilmente. Eles têm um formato específico e, por vezes, são definidos por esta forma, como o caso dos cristais, das esferas, mas, principalmente, eles não percebem em si, tão facilmente, o poder do tempo (BAUMAN, 2001).

Enquanto no outro lado temos os corpos líquidos, que por definição os átomos que o compõem são estruturas mais esparsas e por isto mesmo permitem uma divisão, separação desses corpos. Com a mesma facilidade que são divididos, podem ser reestruturados. Deste modo, percebe-se rapidamente sua capacidade de moldarse às diferentes conjecturas a eles apresentadas, mas, além disso, tem-se que o tempo age mais profundamente sobre estes corpos, pois eles têm capacidade de transpor estruturas, possuem uma facilidade natural quando se visualiza sua adaptabilidade ao longo do passar do tempo, seja este modo mais lentamente ou acelerado (BAUMAN, 2001).

Através disso podemos fazer nossas primeiras suposições, não ao sujeito enquanto ser físico ou o ser pensante, mas sim à sua cultura, suas ideias, suas formas de lidar com o outro. Quando cruzamos estas ideias, temos que a sociedade moderna parte de uma forma de lidar com as construções de uma forma mais sólida, ou 
tradicional, como são mais bem conhecidas. O modernismo ou o pós-modernismo, vem para quebrar com essa forma de lidar com as diferentes configurações de ideias, priorizando as com capacidade mais maleável.

Lancemos visão sobre os processos de aprendizado na pós-modernidade: no período pós-computadores e internet, as informações vêm e vão com uma maior facilidade, o que antes vinha sob a forma de um conhecimento rígido que demorava a se desfazer ou transformar-se e até por vezes permanecia cristalizado, agora tem uma validade muito menor. O conhecimento que agora é verdadeiro, amanhã já pode ter perdido sua validação, ou sua importância. Mas não por isso se faz menos importante na construção de novos ideais na sociedade.

A sociedade pós-moderna lança sobre os indivíduos que a compõem, verdades e concepções científicas de maneira acelerada e sobreposta. Utilizemos um exemplo do nosso cotidiano: o ovo pode representar, durante algum tempo, um alimento não tão positivo, do ponto de vista nutricional, pois foi considerado cheio de calorias, de gorduras, e tão rápido quanto ele foi demonizado, novas informações podem trazer sua importância, como sua composição facilita o desenvolvimento muscular, como ele é importante para saciar o desejo de uma alimentação desregulada. Com o tempo e uma nova reviravolta, este alimento passa a ser relacionado a um mal súbito, tudo isso em curto espaço de tempo ou em algum momento de maneira simultânea. Com esse exemplo, demonstra-se como o conhecimento, através do ciberespaço, é cada vez mais acelerado e, acima de tudo, mutável. Prender-se a padrões é possível, porém, com o avanço cada vez maior da informatização, essa postura talvez não seja mais tão desejada.

Outro elemento que surge das reflexões acerca dos discursos coletados é a construção de indivíduo e as mudanças que este sofreu, seja o ser físico, bem como o sujeito enquanto componente de uma sociedade. Com o advento das novas tecnologias, o indivíduo passa a adquirir, como construção de conhecimento e forma de se ligar à sociedade, o modus operandi de desenvolver seu conhecimento de forma comunitária, ou seja, o sujeito não pensa por si só, ele desenvolve novas concepções e conhecimentos através do pensar de diferentes sujeitos.

Contextualizando isso para a modernidade liquida, ou pós-modernidade, o sujeito quanto mais único e com caracteres diferenciados, mais particular ele irá se constituir. Nessa busca, se joga no campo das concepções consumistas, no próprio capitalismo, no qual o sujeito buscando a particularidade conecta essa à felicidade. 
Deste modo os objetos e vestimentas constituem um poder, ou seja, o indivíduo passa a ser um ser único, individualista e minimamente completo; em outros termos, poderíamos dizer, um ser feliz. Quando este, inserido na sociedade, exalta seu ser através de suas posses únicas e singulares, não se compreende como fixo, ele é mutável de acordo com o que a comunidade o sugere por busca de felicidade.

De forma resumida, as ideias de individualidade e de consumo se misturam, uma vez que essa forma é a que se encontra acessível para ser especial enquanto indivíduo em comunidade. Nas anteriores às sociedades modernas, o conceito de indivíduo se dava através dos aspectos de sujeitos que transmitem a ordenação, ou seja, a maior capacidade de repetição de suas ideias ou representações. Neste ponto, o sujeito se torna um indivíduo quando, de maneira rígida, repete ações ou expõem suas posses e estas se igualam aos outros da sua sociedade, já que nesse ponto o que se pretende espelhar é a igualdade; o ser diferente é tratado com aversão, o distinto não é aceito dentro dessa concepção (MOCELLIN, 2007; BAUMAN, 2001).

De modo geral, nos aspectos sociais, metaforicamente sólidos, temos que:

O indivíduo podia ser distinto e diferente, no entanto, caso desejasse uma aceitação plena deveria se conformar à identidade do Estado a que pertencia. No entanto, os indivíduos já eram entendidos como livres e iguais, podendo exercer direitos e deveres, sendo responsabilizados por suas ações, e sendo livres para empreender a tarefa de construção de uma identidade (MOCELLIN, 2007, p. 109).

Já nos aspectos líquidos:

\begin{abstract}
A modernidade líquida, sem a necessidade de homogeneidade nacional, torna o indivíduo a lei universal, isto é, agora todos devem ser indivíduos. Todos devem ser distintos através de seus próprios recursos. O consumo aqui tem um importante papel, ele se torna, na modernidade líquida, a principal forma de construção da individualidade. Como o consumo, que é passageiro - e se esvai com o fim do desejo - o indivíduo se torna algo móvel, passageiro (MOCELLIN, 2007, p. 109).
\end{abstract}

Não se pode deixar de falar sobre o contexto de felicidade dentro desses paradigmas. As palavras organizativas e estruturantes das relações sociais são: ter, possuir e mostrar. Assim se define como um ser ou sujeito feliz; a ideia de sucesso e prazer não se vincula aos prazeres futuros, se deseja a consolidação do agora, se troca a posse do dinheiro pelo deleite em gastá-lo, por exemplo.

Uma ilustração de felicidade e seu aspecto líquido, ou seja, passageiro, pode se encontrar quando os indivíduos dentro de redes sociais, na internet, se tornam a massiva repetição de uma felicidade exacerbada. O sujeito tenta de toda a forma 
vender, através de suas redes sociais, a perspectiva de uma felicidade plena. E é através desses grandes murais de felicidade compartilhada, que se constroem as visões de uma vida perfeita, ou seja, uma vivência repleta de belos locais, de viagens incessantes, de casais perfeitos. De modo bem resumido, se tem nelas uma felicidade móvel vendida como perene.

Essa felicidade, enquanto um estado de espírito e enquanto emergência da afetividade, pode ser vista nos discursos dos estudantes:

\section{Quadro 6 - As redes sociais e a construção de laços sociais}

\begin{tabular}{|c|c|c|c|}
\hline SUJEITO & DISCURSO & $\begin{array}{l}\text { UNIDADE(S) DE } \\
\text { ANÁLISE }\end{array}$ & CAMPO \\
\hline Aluno A & $\begin{array}{l}\text { "Sim, construo. Como alguns sabem eu sou } \\
\text { presidente de fã-clube. Aí através dele eu } \\
\text { consigo fazer várias amizades diferentes, de } \\
\text { lugares diferentes. É... aí é isso" (RODA DE } \\
\text { CONVERSA, 14/11/2020). }\end{array}$ & Relações sociais & \\
\hline Aluna B & $\begin{array}{l}\text { "Sim, eu também consigo fazer amizades, } \\
\text { assim virtualmente. Até porque eu consigo } \\
\text { criar um vínculo de afeto com a pessoa } \\
\text { virtualmente. Tipo um exemplo é o aluno A. Eu } \\
\text { não tinha nenhum tipo de contato com ele na } \\
\text { sala, a gente só tinha contato visual, e aí } \\
\text { depois que começou essa pandemia, a gente } \\
\text { começou um contato direto no WhatsApp } \\
\text { e a gente criou um vínculo afetivo. É tanto que } \\
\text { isso aconteceu também com outras pessoas... } \\
\text { então eu criei um vínculo com os } \\
\text { professores que eu não conhecia e... criei um } \\
\text { vínculo também com o pessoal da sala que eu } \\
\text { não tinha nenhum tipo de contato" (RODA DE } \\
\text { CONVERSA, 14/11/2020). }\end{array}$ & $\begin{array}{l}\text { Relações sociais } \\
\text { Afetividade } \\
\text { Virtualidade } \\
\text { Mediação das } \\
\text { redes sociais } \\
\text { Criação de vínculo }\end{array}$ & \\
\hline Aluno C & $\begin{array}{l}\text { "Sim professora, eu consigo muito. Dos três } \\
\text { idiomas que eu quero aprender muito, o } \\
\text { principal é inglês, que a gente é quase } \\
\text { obrigado a saber o inglês, e pra aprender eu } \\
\text { fiz amizade com pessoas de outros países } \\
\text { sabe. Tanto que eu conheço, eu virei amigo } \\
\text { mesmo de pessoas da Espanha, da França, } \\
\text { da Turquia e Portugal. E assim, as redes } \\
\text { sociais ajudam muito, né? Antes pra você } \\
\text { conhecer alguém de outro país você teria que } \\
\text { ir lá ou ela vir aqui. Hoje a gente pode apenas } \\
\text { curtir uma foto e começa uma conversa" } \\
\text { (RODA DE CONVERSA, 14/11/2020). }\end{array}$ & $\begin{array}{l}\text { Aprendizagem } \\
\text { social } \\
\text { Redes sociais } \\
\text { Curtidas }\end{array}$ & \\
\hline Aluno D & $\begin{array}{l}\text { "Através das redes sociais a gente consegue } \\
\text { sim construir afetividade. Porém, não } \\
\text { aquela afetividade genuína de tá ali com a } \\
\text { pessoa, é... perto, ter aquele contato. Mas } \\
\text { sim, dá sim pra construir uma afetividade, } \\
\text { fazer novas amizades, aproxima muito as }\end{array}$ & & \\
\hline
\end{tabular}


pessoas também. E... até possibilitando conhecer muitas pessoas novas, até de outros lugares que a gente talvez não conhecesse. Mas as redes sociais têm ajudado bastante sim nessa questão" (RODA DE CONVERSA, 14/11/2020).

Fonte: A autora (2020).

O tempo, na construção das ideias aqui verificadas, vem como um uma ferramenta de modificação, de desconstrução. O tempo é o principal fator determinante entre uma sociedade moderna e uma pós-moderna, pois é este que irá determinar quais as ideias e concepções aptas para se modificarem e se adaptarem às novas versões dos sujeitos e das sociedades seguintes.

A modernização das comunidades implica uma diluição e aceleração do tempo e espaço, mais uma vez se atrelado às concepções de virtual e ciberespaço. Isso gera uma necessidade social de estruturação dentro de um ambiente em que o tempo percorra o dobro de sua velocidade, que o espaço deixe de ter seu significado se tornando um não-lugar, ou uma representação destes na forma de virtualidade.

Para que se compreenda mais facilmente, as formas que o tempo e espaço tomam nas perspectivas da modernidade líquida, vêm do fator das coisas poderem mudar e se adaptarem a novas formas. O tempo seria o agente proporcionador destas mudanças, já que com ele se determina a passagem e o período de validade das coisas, lugares, pensamentos. E quando estes podem ser utilizados ao máximo e, por fim, lançados fora com desprendimento, pertencem ao ambiente pós-moderno.

No caso dos lugares, temos que o espaço assume a forma de acordo com que se relaciona a algo. Um lugar tradicional seria aquele que possui situações ou ideias vinculadas a ele. Quando este espaço não possui nenhuma relação deste tipo, ele é colocado como um não-lugar e este serve como uma passagem para diferentes tipos de sujeito, e quando estes estão inseridos neste local, perdem completamente suas características e se tornam comuns.

De maneira mais direta, tornam-se todos iguais, semelhantes, padronizados. $O$ virtual, como já visto anteriormente, seria nada mais do que a representação desses espaços dentro de um campo que não existe enquanto estrutura física (MOCELLIN, 2009; FRAGOSO, 2011; PORCHEDDU, 2009; BAUMAN, 2001). 
significado surge a partir de seus ocupantes, que devem o significar. É um lugar demarcado pela cultura de seus ocupantes. E reciprocamente, a cultura de seus ocupantes depende da forma como encaram o lugar. Tem-se associado essa concepção tradicional de lugar à formas de vida tipicamente pré-modernas - vilarejos fechados, aldeias indígenas, feudos medievais, pequenas cidades - caracterizadas por uma cultura muitas vezes bastante homogênea, com baixa diferenciação e elevada coesão de interesses entre os membros (MOCELLIN, 2009, p. 79).

Compreender estas diferentes formas de espaço, nos auxilia quando tentamos entender as relações entre os sujeitos nas sociedades modernas. Como exemplo, utilizemos uma suposição simples: quando dois sujeitos se encontram em uma praça, esta sendo um espaço tradicional, vinculado a ela existe toda a sorte de ideias e informações. Estes dois sujeitos pertencentes ao ambiente de pós-modernidade se chocam ao passar um pelo outro. De acordo com os aspectos da modernidade líquida, os dois agora travam uma batalha de poderes, não necessariamente física, mas, cada um em sua individualidade, tenta demonstrar o seu status, seja através de postura ou de exposição de bens materiais.

Agora imaginemos essa mesma situação ocorrendo dentro de um aeroporto, de uma rede de fast food, estes por não possuírem uma correlação de ideias, sendo somente um campo de passagem. Ambos os sujeitos, ao estarem nessa situação, nesse local, se tornam nulos um perante ao outro, ou seja, eles não tem um patriotismo vinculado a este local. Nesse ponto, ambos se tornam nulos um perante o outro naquele ambiente. E, por fim, a relação de toda essa discussão com as interações no campo da internet, uma vez que esta seria uma representação virtual do ambiente físico, as mesmas ações e interações são passiveis de ocorrer. E podem ser observadas através das interações e atritos dos sujeitos no campo das redes sociais. O espaço e tempo apresentam relações entre si e distribuem-se sobre as relações sociais em formas específicas (MOCELLIN, 2009; FRAGOSO, 2011; PORCHEDDU, 2009; (BAUMAN, 2001).

$E$, por fim, estas interações se dão através de dois vieses: o antropofágico e o antropoêmico, que se definem como: o primeiro como sendo o modo no qual se suga, expurga tudo, que não se possui de característica do grupo dominante, do outro sujeito. Ou seja, se pega o outro e retira-se dele tudo o que lhe faz diferente do grupo dominante até que se torne igual a este. Podendo ser através de alienação ou de ações como as que ocorrem nas guerras. Já o segundo, antropoêmico, é o processo de isolamento do outro, a exclusão da sua existência e dos seus laços sociais, ou seja, ele é impedido de qualquer função social, ou pelo menos são suprimidas ao 
máximo essas funções; podem ser adotados como exemplos o encarceramento, a separação espacial, o acesso seletivo destes locais (BAUMAN, 2001).

$\mathrm{Na}$ educação, essas construções vêm a fim de provocar modificações. Nas primeiras, temos a desmitificação e quebra das ideias fixas, o mundo líquido, moderno em si mesmo, interpreta essas ideias como algo a ser combatido. Tudo aquilo que se limita impedindo a liberdade de exercer suas funções, que impedem o sujeito de galgar de um conhecimento para outro e construir as relações de saberes sobre estes, está fadado a ser deixado de lado, ser tratado como obsoleto e por fim, modificado. Isso tudo até que se torne fluído e maleável, dentro da vivência de cada indivíduo. Já que o fator duradouro não é mais uma qualidade para favorecer as coisas, pois na modernidade as coisas e ideias são úteis durante um tempo fixo, permitindo sua máxima utilização, e posteriormente sua eliminação imediata, não permitindo ou desejando seu acúmulo. As ideias devem ser aproveitadas e tão logo percam sua influência sejam descartadas e substituídas por novas.

Como paradigma seguinte, temos as ideias de que a base pedagógica pressupõe o conhecimento como algo representante do ambiente fixo - ou quando mutável, necessitando de longo prazo, permitindo a previsibilidade do conhecimento, uma vez que a sociedade está em constante mudança e sua visão de ambiente, bem como das informações geradas por este, também apresentam grande variação. Isso faz com que essa base tenha de ser repensada e alterada.

E através dessa mudança, uma reafirmação do primeiro ponto é realizada: um grande ciclo do conhecimento que determina a mudança nas suas bases. Lembrando sempre que as mudanças a cada período se aceleram mais, sendo uma verdadeira batalha para manter-se em paralelo às mudanças na sociedade e as causadas por ela na educação (PORCHEDDU, 2009). Assim,

A história da pedagogia esteve repleta de períodos cruciais em que ficou evidente que os pressupostos e as estratégias experimentadas e aparentemente confiáveis estavam perdendo terreno em relação à realidade e precisavam, pois, ser revistos ou reformados. Todavia, parece que a crise atual é diversa daquelas do passado. Os desafios do nosso tempo infligem um duro golpe à verdadeira essência da ideia de pedagogia formada nos albores da longa história da civilização: problematizam-se as "invariantes" da ideia, as características constitutivas da própria pedagogia (que, incólumes, resistiram às mudanças do passado); conviç̧ões nunca antes criticadas são agora consideradas culpadas de ter seguido o seu curso e, portanto, precisam ser substituídas... Gostaria de repetir o que foi dito no começo: no ambiente líquido moderno, a educação e o aprendizado, não importa o uso que se faça deles, devem ser contínuos e permanentes. O motivo determinante para o qual a educação deve ser contínua e permanente está 
na natureza da tarefa que devemos desenvolver no caminho comum da "outorga dos poderes", uma tarefa que é exatamente como deveria ser a educação: contínua, ilimitada, permanente (PORCHEDDU, 2009, p. 662).

O sujeito e sua relação fluida através das redes sociais com os outros grupos, como as novas formas de entender o outro, são visíveis na postura tomada em espaços virtuais. $O$ entendimento do outro não é alguém que se relaciona diretamente, só o que se observa são seus resquícios de desejos, vontades de ser um ser único.

Isso vai nos mostrando a construção do ser social e suas formas de se expressar, este com a sua capacidade de adaptabilidade, fluido e apto a se modificar perante novas questões. Mostra também como o processo de defesa de seus territórios e locais de relação, afetividade, e como as ferramentas tecnológicas aproximam o sujeito de uma gama de informações, de sensações e estes perpassam elas, utilizam-nas, deleitam de suas companhias e seguem abandonando-as e seguindo seu curso nas redes sociais. Assim, temos:

\section{Quadro 7-O Eu nas redes sociais}

\begin{tabular}{|c|c|c|c|}
\hline SUJEITO & DISCURSO & $\begin{array}{l}\text { UNIDADE(S) DE } \\
\text { ANÁLISE }\end{array}$ & CAMPO \\
\hline Aluno A & $\begin{array}{l}\text { "Assim, eu vou falar a verdade. Nas redes } \\
\text { sociais, quando tá rolando alguma treta assim, } \\
\text { eu vou lá, meto a cara e brigo mesmo. Agora, } \\
\text { brigar assim, fisicamente, Deus me livre, tô } \\
\text { fora! Agora assim professora, em questão de } \\
\text { fazer amizade, na internet eu faço facilmente, } \\
\text { agora assim, fisicamente também faço, nessa } \\
\text { questão eu sou igual na internet e fora da } \\
\text { internet" (RODA DE CONVERSA, 14/11/2020 }\end{array}$ & $\begin{array}{l}\text { Ação } \\
\text { Realidade física }\end{array}$ & \\
\hline \multirow[t]{2}{*}{ Aluna B } & $\begin{array}{l}\text { "Eu sou bem de boa, então tipo da mesma } \\
\text { forma em que eu é... tipo ajo com a pessoa } \\
\text { naturalmente virtualmente, eu ajo com ela } \\
\text { naturalmente pessoalmente. Digamos que } \\
\text { pelo WhatsApp trato com maior amor do } \\
\text { mundo, maior carinho, "Bom dia amor, bom } \\
\text { dia paixão", essas coisas. Tipo você } \\
\text { conversando comigo diariamente, } \\
\text { pessoalmente, eu vou ser a mesma coisa, não } \\
\text { vou mudar por causa disso. E eu evito treta de } \\
\text { qualquer tipo que seja, seja ela virtual, seja ela } \\
\text { pessoal, eu evito qualquer forma, porque isso } \\
\text { não me faz bem, não é uma coisa que me faz } \\
\text { bem entrar em treta. Mas aí o povo me chama, } \\
\text { bota meu nome, fazer o quê!" (RODA DE } \\
\text { CONVERSA, 14/11/2020). }\end{array}$ & $\begin{array}{l}\text { Ação } \\
\text { Virtual }\end{array}$ & UI \\
\hline & $\begin{array}{l}\text { "Eu me considero a mesma pessoa, } \\
\text { professora. Eu acho que eu sou um pouco }\end{array}$ & & \\
\hline
\end{tabular}




\begin{tabular}{|c|c|c|}
\hline Aluno C & $\begin{array}{l}\text { tímido, nas redes sociais também, tanto que } \\
\text { eu não posto muitas fotos, não coloco muitos } \\
\text { status, muitos stories. Eu já me considero } \\
\text { tímido, sabe...Mas, todos os meus } \\
\text { princípios, vamos dizer assim, que eu ponho } \\
\text { nas redes sociais, é o mesmo que eu acho, } \\
\text { é a mesma coisa que eu defendo (RODA DE } \\
\text { CONVERSA, 14/11/2020). }\end{array}$ & $\begin{array}{l}\text { Princípios } \\
\text { Exposição }\end{array}$ \\
\hline Aluno D & $\begin{array}{l}\text { "Eu sou uma pessoa que eu diria assim, mais } \\
\text { restrita, eu num utilizo tanto redes sociais } \\
\text { assim pra questão de divulgação de vida, } \\
\text { como muitas pessoas fazem, fazem da rede } \\
\text { social até um diário da vida da pessoa. Então } \\
\text { essa questão quem sou eu nas redes } \\
\text { sociais, eu sou bem restrito, mas também } \\
\text { assim fora das redes sociais eu sou um cara } \\
\text { brincalhão, sou sociável. Então, tem essa } \\
\text { distinção um pouco entre eu nas redes } \\
\text { sociais e eu na... fora das redes" (RODA DE } \\
\text { CONVERSA, 14/11/2020). }\end{array}$ & $\begin{array}{l}\text { Eu } \\
\text { Dentro das redes } \\
\text { sociais } \\
\text { Fora das redes } \\
\text { sociais } \\
\text { Diferença }\end{array}$ \\
\hline
\end{tabular}

Fonte: A autora (2020).

De mesmo modo que se relaciona e entende o outro como algo passageiro, sua própria realidade, sua postura e costumes dentro do espaço virtual, também é algo passageiro. Lá, nas redes sociais, percebe-se que se pode ser o que quiser em diferentes frentes, conseguindo assumir posturas diferentes de acordo com o espaço por ele ocupado. Isso traz implicações para as formas como sabemos e conhecemos a realidade. Seguem os discursos dos estudantes:

\section{Quadro 8 - As redes sociais e o saber}

\begin{tabular}{|c|c|c|c|}
\hline SUJEITO & DISCURSO & $\begin{array}{l}\text { UNIDADE(S) DE } \\
\text { ANÁLISE }\end{array}$ & CAMPO \\
\hline Aluno A & $\begin{array}{l}\text { "É... na maioria das vezes sim, porque o } \\
\text { professor passa um assunto e tal, tem aluno } \\
\text { que fica com vergonha de pedir pra ele } \\
\text { explicar novamente, aí você tendo o acesso à } \\
\text { internet, você vai pesquisar mais um pouco } \\
\text { sobre aquilo que ele passou. Aí nessa } \\
\text { questão dá pra aprender mais um } \\
\text { pouquinho" (RODA DE CONVERSA, } \\
\text { 14/11/2020). }\end{array}$ & $\begin{array}{l}\text { Internet } \\
\text { Aprendizagem }\end{array}$ & $\boldsymbol{\alpha}$ \\
\hline Aluna B & $\begin{array}{l}\text { "Boa parte das coisas, principalmente agora } \\
\text { depois que a gente começou com o ensino } \\
\text { virtual, tem muita coisa que... pronto, os } \\
\text { professores passam um vídeo de vinte, trinta } \\
\text { minutos, e mesmo assim fica alguma dúvida, } \\
\text { eu vou lá, procuro algum vídeo de cinco, seis } \\
\text { minutos, que explique a mesma coisa e que } \\
\text { eu entenda bem mais... às vezes eu não } \\
\text { entendo uma palavra, uma coisa, outra e }\end{array}$ & & $\boldsymbol{D}$ \\
\hline
\end{tabular}




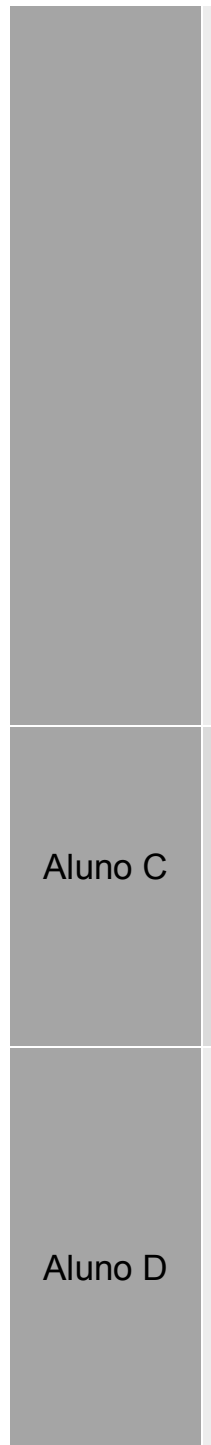

procuro a internet como uma forma de ajuda, porque muitos professores são muito ocupados, tem outros empregos também, outras escolas, tem responsabilidade em casa e não pode tá ali disponível pra mim vinte e quatro horas pra hora que eu tiver dúvida ele simplesmente chegar lá e tirar. Aí eu tenho que me virar com a internet pra tentar aprender da minha forma. Então eu acho que é um meio que a gente aprende bastante, usando as redes sociais. Não só a internet em casa mas também na escola, que a gente tem alguma coisa, a aula do professor já passou, ou então tem vergonha de perguntar... e a gente acaba pesquisando na internet o que mais ou menos seria aquilo" (RODA DE CONVERSA, 14/11/2020).

"Sim, professora. Eu sempre usei demais. Mesmo antes da pandemia eu sempre usei as redes sociais porque além da explicação do professor, eu gosto de ver outras aulas, com outros métodos e praticar muito é... o assunto" (RODA DE CONVERSA, 14/11/2020).

"Na escola não, até porque eu tinha falado isso antes. Seria uma boa pra escola é... ativar as aulas de informática, até pra gente aprender também bastante com isso. Então, como não tem muito essa interação da informática na escola, a gente não... pelo menos eu não tenho utilizado as redes sociais nem nada assim pra aprender lá dentro" (RODA DE CONVERSA, 14/11/2020).

\section{Redes sociais}

Prazer

\section{Ensino}

Virtual

Ação

\section{Autonomia}

Aprendizagem

\section{Currículo}

Interação

Fonte: A autora (2020).

As relações com o saber são mais rápidas; a escola não é mais fonte de conhecimento única, o professor tem que entender que as coisas fluem, mudam e com isso os novos campos para adquirir o saber também. O processo de aprender e absorver o conhecimento deve partir do sujeito que utiliza as redes sociais, ele que em sua construção determinara o que é utilizável, quanto tempo poderá utilizar e o principal, quais informações pode, deve ou não absorver. Essa relação com o saber possibilita um tipo de projeto social sobre o futuro das relações, das instituições e das sociedades. Modos outros de existir socialmente, acabam emergindo desse contexto. Assim, temos 


\section{Quadro 9 - As redes sociais e o futuro}

\begin{tabular}{|c|c|c|c|}
\hline SUJEITO & DISCURSO & $\begin{array}{l}\text { UNIDADE(S) DE } \\
\text { ANÁLISE }\end{array}$ & CAMPO \\
\hline Aluno A & $\begin{array}{l}\text { "É... realmente, obviamente, será algo mais } \\
\text { avançado né? é... vai facilitar muito mais as } \\
\text { coisas, e até a aprendizagem mesmo (RODA } \\
\text { DE CONVERSA, 17/11/2020). }\end{array}$ & Desenvolvimento & \\
\hline \multirow[t]{2}{*}{ Aluna B } & $\begin{array}{l}\text { "Eu acho que vai ser uma coisa que a gente } \\
\text { vai ter que se acostumar, principalmente } \\
\text { agora, de agora por diante, e é uma coisa } \\
\text { nova pra gente, mas para as gerações que } \\
\text { estão vindo vai ser bem melhor e é uma coisa } \\
\text { que eles já vão estar acostumados e tal. E } \\
\text { digamos que vai ser bem melhor o ensino, a } \\
\text { forma que eles vão aprender, porque tipo, a } \\
\text { gente tem uma certa dificuldade em ter aula } \\
\text { online, mas eles como já vão estar aptos com } \\
\text { aquilo, já vão crescer com aquilo, vão ter uma } \\
\text { facilidade maior em aprender, em casa, em } \\
\text { aprender online. E também vai ser bom, } \\
\text { porque tipo, é como se eles tivessem dois } \\
\text { tipos de sala de aula, e aí eles podem } \\
\text { aproveitar os dois tipos de sala de aula... vai } \\
\text { ser bem legal!" (RODA DE CONVERSA, } \\
\text { 17/111/2020). } \\
\text { "Ô, professora, eu tava pensando, também vai } \\
\text { ser uma dificuldade, porque hoje a } \\
\text { população certo, beleza... digamos que } 80 \% \\
\text { da população tem tecnologia em casa, } \\
\text { independente de qual seja, de uma televisão } \\
\text { a um celular, de um computador a qualquer } \\
\text { outra coisa... mas, também, a tecnologia além } \\
\text { de ajudar muito vai ser uma dificuldade lá na } \\
\text { frente, porque hoje, digamos que...beleza, eu } \\
\text { tenho condições de assistir aula online } \\
\text { porque eu tenho um celular, eu tenho } \\
\text { computador, e minha mãe tem condições de } \\
\text { me dar um computador, graças a Deus. Mas } \\
\text { também, tem aquelas pessoas que não tem } \\
\text { condições de ter um celular, não tem } \\
\text { condições de ter é... um computador, elas não } \\
\text { têm condições de ter aula online. É tanto que } \\
\text { tem casa que é só um aparelho pra quatro, } \\
\text { cinco seis pessoas assistirem aula. Então } \\
\text { certo, beleza, vai ser muito bom, vai ajudar } \\
\text { bastante, mais também vai ser uma } \\
\text { dificuldade enorme" (RODA DE CoNVERSA, } \\
17 / 11 / 2020) \text {. }\end{array}$ & $\begin{array}{l}\text { Desafios } \\
\text { Igualdade social } \\
\text { Disparidade }\end{array}$ & \\
\hline & $\begin{array}{l}\text { "Mesmo antes da pandemia a gente já tinha } \\
\text { falado isso na escola, que eu acredito que } \\
\text { daqui há alguns anos o ensino será remoto } \\
\text { mesmo né, o ensino será online. É... e a } \\
\text { pandemia meio que acelerou muito mais isso, } \\
\text { porque foi como... quero pegar o exemplo de } \\
\text { um estágio, quando você vai fazer um estágio }\end{array}$ & & \\
\hline
\end{tabular}




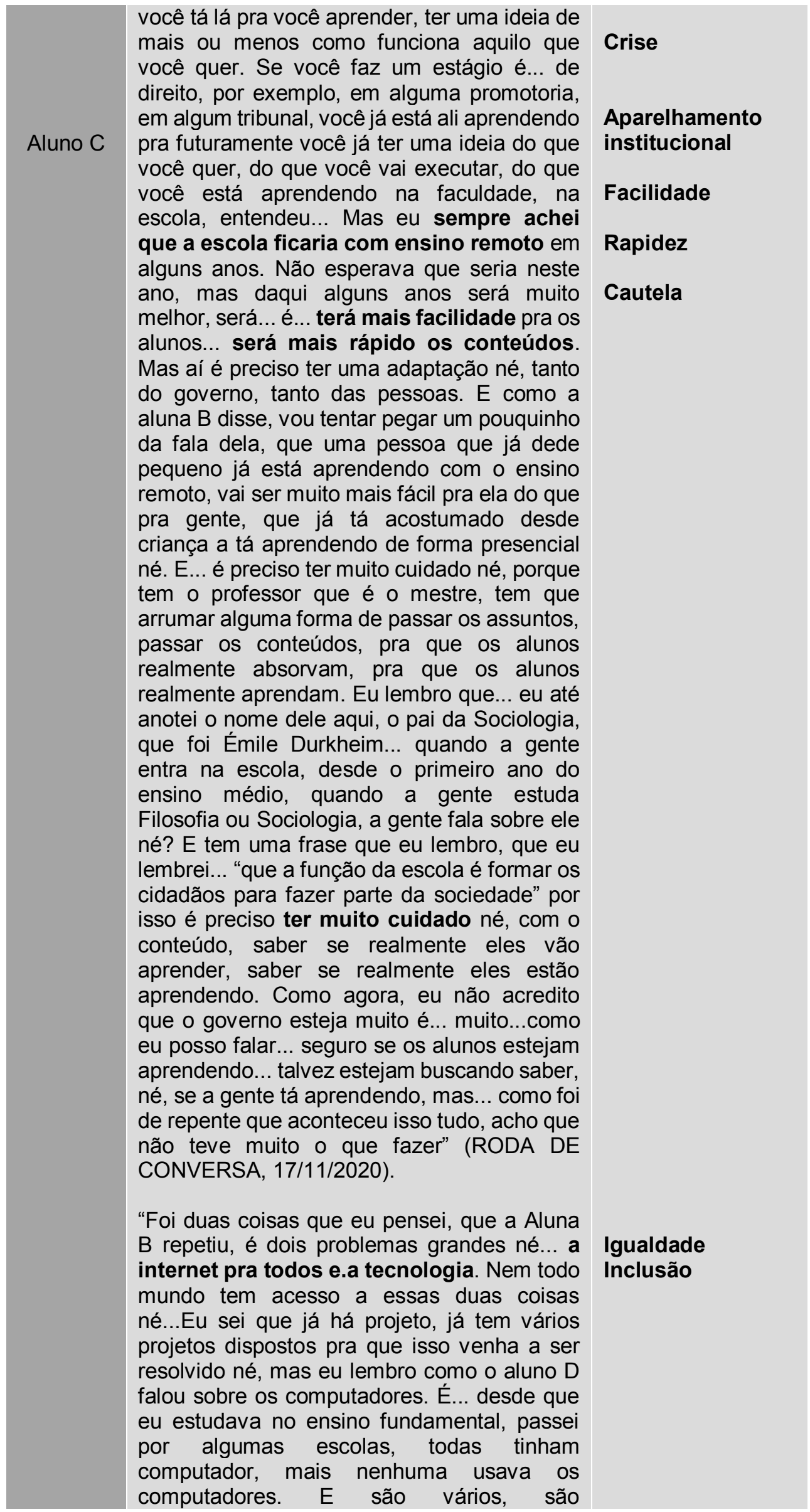




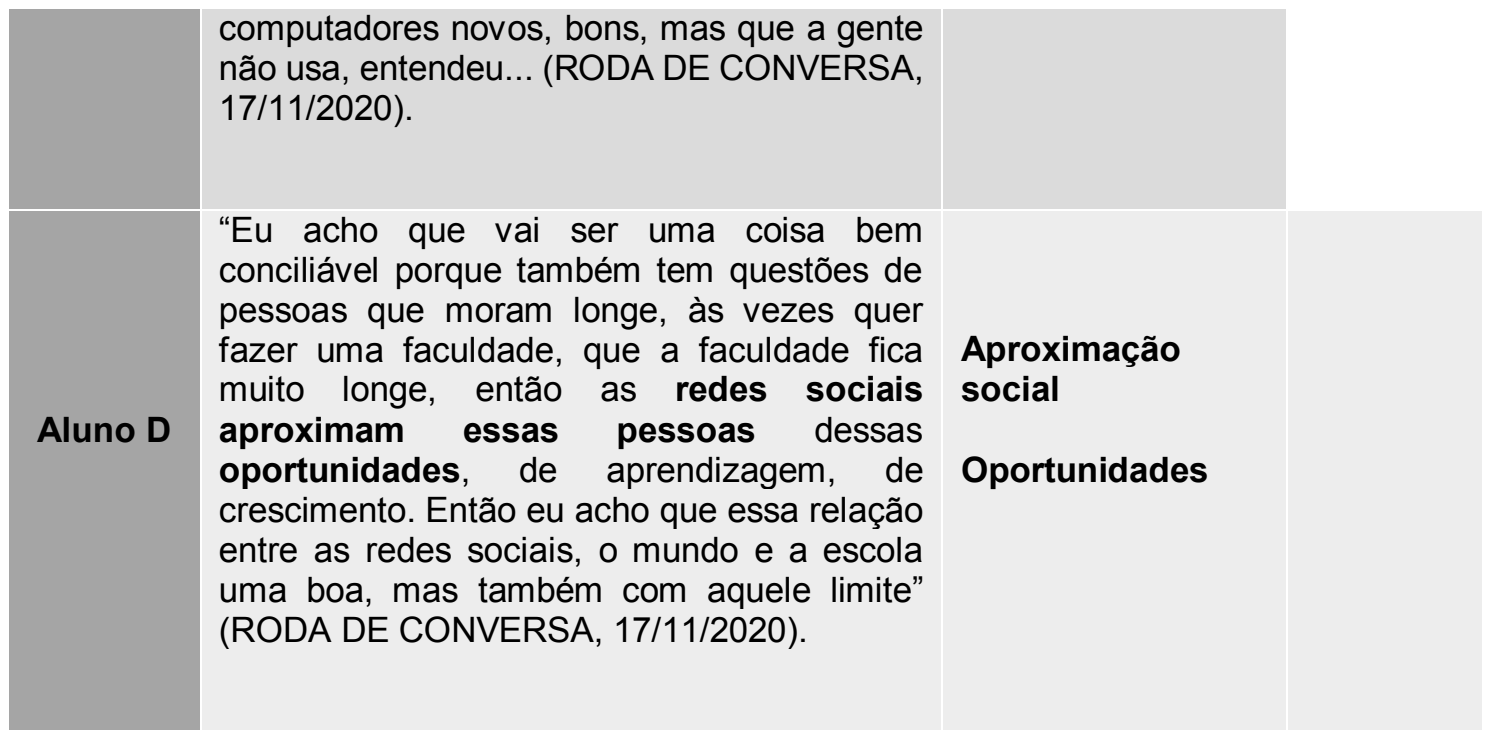

Fonte: A autora (2020).

O consumo, o absorver de novos produtos, novas tecnologias, mesmo que estes sejam os básicos, as novas ferramentas que são necessárias para se adaptar a um ambiente e se sentir completo, pleno em sua usabilidade social, e com isso a realização do deleite, a felicidade de se perceber enquanto indivíduo que possui, que é único e que faz parte de um grupo cultural. Tudo isso constitui enquanto demandas imediatas da realidade virtual. Implica, portanto, em se entender enquanto um ser que percebe o tempo futuro com os olhos do presente, ou seja, uma visualização da quebra, futura, das bases que possui.

5.5 O aparelhamento digital, produção do conhecimento e as aulas de sociologia

As novas tecnologias fundamentam outros paradigmas que enfrentam os educadores na passagem de conhecimento para outros indivíduos e na construção desse conhecimento. Frente a isso analisamos sob a ótica de três conceitos sociológicos, sendo um deles redividido em outros, mas, comecemos pelo básico, pois nele temos o habitus, o campo e o capital. Este último, que por sua vez é dividido em capital econômico, capital simbólico, capital social e o capital cultural.

Portanto, temos o indivíduo com suas concepções e ideias internalizadas, sua caraterísticas, vícios e afetos, sejam elas absorvidas ao longo da sua relação com a sociedade como um todo ou com as relações familiares desde o seu nascimento. Nesse aspecto se tem a essência do sujeito: o que ele acredita, o que torna ele único. 
Temos então, a percepção do sujeito enquanto único, pois esta perspectiva tem como elemento principal a caracterização do sujeito, ou seja, o habitus. São as características distintas e que distinguem os indivíduos, quando em sociedade seriam todas as formas que o corpo encontra para se representar perante a comunidade, seja em suas ações, em seus gostos ou pensamentos e posturas (PINÇON; PINÇONCHARLOT, 1999).

Atrelado a isso temos o entendimento de ambiente, ou como verificado anteriormente no corpo desse texto, a percepção de espaço. Aqui recebe a caracterização de campo e é nele - seja real ou virtual - onde ocorrem as trocas de informações ou processos de relações entre os sujeitos. Esse espaço tem relação direta nas buscas que o sujeito pretende realizar ao se localizar nele. É no local em que o indivíduo percebe o outro, e através deste ponto em comum se estruturam as relações de poder entre ambos, ou seja, o campo tanto irá auxiliar a definir as posições entre os sujeitos, bem como também irá iniciar o trajeto que o sujeito pretende fazer em suas ações ou ideias (PINÇON; PINÇON-CHARLOT, 1999).

Imaginemos os sujeitos que se encontram no campo escola. Estes sujeitos pelo simples fato de estarem pertencentes a esse ambiente já são colocados em configurações de poder iguais: estudante-estudante, educador-educador. Ou em locais de prestígio diferentes: estudante-professor. Com isso já se entende, ou pelo menos se tem conjecturado, o caminho que a informação e o poder arraigado nela irá realizar, e também se é possível traçar os caminhos pretendidos por ambos os sujeitos no ambiente. De outro modo: como estão em um ambiente escolar, o que se busca por ambos são as ações de passagem de conhecimento e toda a sorte de conceito vinculado a esta.

No terceiro conceito temos o capital que faz referência a diversos pontos, mas todos eles se ligando a poder, à capacidade de ser convertido em valores monetários, ser monetizados. Capital econômico, de maneira mais geral, é o poder advindo da renda, do salário, este sendo possuído por um indivíduo e que é através dele que precifica suas construções, sejam de saberes ou culturais. E com esse construto de alto grau de importância, forma sua colocação social, ou seja, através desse capital é que se define o sujeito dentro das diversas comunidades. Capital cultural são os conhecimentos e informações que são reconhecidos e comprovados através de diplomas, ou seja, o conhecimento institucionalizado, o conhecimento adquirido com o exercício da educação formal. Capital social pode ser as relações entre o indivíduo, 
nos moldes que ambos ou pelo menos um deles possa ter algum tipo de lucro capital, bem como as relações de trabalho ou os contatos que se relacionam por consequência de investimento pessoal. Capital simbólico, este seria o de mais fácil entendimento: é o que denominamos de honra, o prestígio que o sujeito possui para determinadas sociedades (PINÇON-CHARLOT, 1999).

Nos espaços virtuais, como uma grande representação dos campos da realidade, tais aspectos e posturas se repetem, de modo a se perceber essa troca entre sujeito nas relações sociais. No conceito de habitus, nós temos o sujeito carregado com todas as suas características e formações de pensamento; no meio das redes sociais somos sempre apresentados a perfis de informações dos indivíduos. Neles, tenta-se defini-lo através de suas características e é com isso que irá se relacionar, não se tem interação direta e demorada com o indivíduo, dono daquelas características. Temos é acesso aos vestígios deixados na sua timeline, e através de seus gostos e de suas características seriam as afinidades entres os sujeitos. No campo retomamos a importância do espaço virtual como um campo de definições de posturas, cada rede social pelo sujeito organiza em sua essência um norte para suas interações (MERCADO, 2002).

Enquanto em algumas o sujeito deve mostrar-se seja feliz, triste, seja alimentado ou revoltado, sempre com o chamariz principal: a imagem. Já em outras, o pensamento rápido, a discussão acelerada, a abordagem de diferentes temas, a maleabilidade em se expressar é o que é solicitado. Em terceiros tipos, temos a própria substituição das relações pessoais: o indivíduo não se relaciona mais diretamente com o outro, se relaciona com a máquina ou aparelho, e este se relaciona com o outro sujeito, intermediando suas conversas na forma de textos ou de ligações. Ou seja, para cada rede social, em cada campo um aspecto da comunicação é empregado: o primeiro é a imagem, o segundo o texto curto e rápido e constringido de informações, no terceiro a própria relação dos indivíduos é mediada pela máquina, suprimindo a necessidade de proximidade entre os sujeitos (MERCADO, 2002).

Por última aplicação, temos o capital. Este que de fato é utilizado como obtenção monetária e se aplica como forma de conceder ou reafirmar o poder, sendo de mesma forma aplicado nas suas diferentes áreas, apresentadas anteriormente. A escola como um ambiente social é impregnada dessa afirmação, dessa concessão da ideia de que um sujeito possui poderes sobre o outro, ou mutuamente. O que se ensina, o conhecimento em si mesmo, tem sua valoração; o que é ensinado, o que é 
repassado, é aquilo que é superior perante outras ideias, perante outras concepções, e esse conhecimento difundido vem de uma classe superior. O que é considerado inferior não se pode reproduzir, deve ser esquecido, seu conhecimento deve ser expurgado (LOSTADA, 2011; PINÇON-CHARLOT, 1999).

O foco principal dessa teoria é entender como o todo se constitui, como as relações entre sujeitos no meio social real ou virtual se compõem, quem naquele campo é possuidor do capital, e ao visualizar isso, entender como é equivocada a sua naturalização, a relação de subjugar um sujeito em relação ao outro pelo seu poder cultural ou seu capital social, e esta postura deve ser combatida. Afirma Lostada (2011, p. 395):

\begin{abstract}
A escola reprodutora, diante da dinâmica da pós-modernidade, está em crise, pois, tratando-se de uma instituição que só pode preencher sua função de inculcação enquanto é mantida a adequação entre a mensagem pedagógica e a aptidão dos receptores em decifrá-la, dado o crescimento do público e o tamanho da organização, não pode preencher sua função sem pressupor estudantes com um capital linguístico e cultural de acordo com o que ela consagra, sem exigi-lo expressamente, nem transmiti-lo metodicamente.
\end{abstract}

O aparelhamento dos indivíduos em sala de aula gera dois pormenores de acordo com a perspectiva dessa teoria: em primeiro ponto temos os sujeitos agora dominadores de ferramentas cabíveis para quebrar esse ciclo. Assim, vemos a naturalização de que o grupo superior é quem determina o que deve ser aplicado em principal, e subjugando outras formas de conhecimento. Em outras frentes, o embate contra os ditames da reprodução social, impedindo a subserviência de um grupo menos abastado perante uma classe mais favorecida. No outro ponto, temos como exposto, inicialmente, as redes sociais ou novos aparelhos tecnológicos servindo simplesmente como uma máquina de potencialização, de intensificação das condições de classificações sociais, seja através da reprodução do discurso de um grupo com capital cultural superior (LOSTADA,2011).

As novas propostas não são apenas a utilidade das tecnologias em sala de aula, mas também a aplicabilidade de novas formas de exposição, novas maneiras de se chegar no estudante. As tecnologias servem como ferramenta facilitadora desse processo, e como uma janela de novas perspectivas e, consequentemente, quebra de paradigmas. Podemos ver isso nos seguintes discursos, quando anunciam o que consideram um bom trabalho didático e pedagógico frente às tecnologias e aos aparelhos digitais nas aulas de Sociologia: 
Quadro 10 - As aulas de sociologia

\begin{tabular}{|c|c|c|c|}
\hline SUJEITO & DISCURSO & $\begin{array}{l}\text { UNIDADE(S) DE } \\
\text { ANÁLISE }\end{array}$ & CAMPO \\
\hline Aluno A & $\begin{array}{l}\text { "Quando ele (o professor), assim quando ele } \\
\text { faz uma explicação que a maioria dos alunos } \\
\text { tire suas dúvidas. Aí ele passa uma atividade } \\
\text { de acordo com aquilo que a gente aprendeu" } \\
\text { (RODA DE CONVERSA, 17/11/2020). } \\
\text { "É aquela questão que a aluna B falou. Não } \\
\text { adianta o professor explicar e o aluno não } \\
\text { entender e dizer que entendeu. O aluno tem } \\
\text { que realmente falar que entendeu. Agora tem } \\
\text { aluno que não entende e fala que entendeu } \\
\text { e isso é um ponto negativo" (RODA DE } \\
\text { CONVERSA, } 17 / 11 / 2020 \text { ). } \\
\text { "Bom, a minha, a que eu mais gosto é } \\
\text { Química. Porque a gente tem o prazer de } \\
\text { expandir o assunto, como o corpo humano, } \\
\text { é... é... (pausa)... o que...como é meu Deus... } \\
\text { o corpo humano... quando é alguma coisa que } \\
\text { existe na água, porque a gente não saiba, por } \\
\text { exemplo. É só isso" (RODA DE CONVERSA, } \\
17 / 11 / 2020 \text { ). }\end{array}$ & $\begin{array}{l}\text { Racionalidade } \\
\text { Ação }\end{array}$ & \\
\hline Aluna B & $\begin{array}{l}\text { "Eu acho que a maneira de interação com os } \\
\text { alunos e a forma de explicar. Tipo o professor } \\
\text { explicou a matéria, viu que o aluno não } \\
\text { entendeu e mesmo assim insiste em explicar } \\
\text { novamente, tirar as dúvidas do aluno pra que } \\
\text { ele aprenda o assunto e não o que explique e } \\
\text { fique por isso mesmo" (RODA DE } \\
\text { CONVERSA, 17/11/2020). } \\
\text { "Eu acho que ficar só ensinando determinado } \\
\text { tipo de ensinamento. Tipo você pode fazer } \\
\text { várias coisas, não só teoria, mas como } \\
\text { prática também pra um bom ensino. E } \\
\text { muita gente se prende mais em passar só } \\
\text { teoria. É tipo assim, o professor pode fazer } \\
\text { Power Point, pode fazer brincadeira, pode } \\
\text { passar trabalho, pode fazer várias e várias } \\
\text { coisas pra que o assunto seja um assunto } \\
\text { legal e que o aluno aprenda. Mas aí eles se } \\
\text { prendem a passar apenas uma teoria, } \\
\text { escrever no quadro e dar explicação de } \\
\text { sempre. Isso é um ponto negativo" (RODA DE } \\
\text { CONVERSA, 17/11/2020). } \\
\text { "Bom, eu gosto mais da parte de... tipo eu me } \\
\text { identifico mais com Sociologia e Filosofia. } \\
\text { Porque são duas matérias que falam muito } \\
\text { sobre a sociedade, sobre realidade, sobre } \\
\text { filósofos que eu gosto, essas coisas e tal. E } \\
\text { sobre antepassados tipo, e prevê muita coisa } \\
\text { do futuro. Aí a gente estuda pelo que tá } \\
\text { acontecendo e tal, você tem uma base do }\end{array}$ & $\begin{array}{l}\text { Realidade social } \\
\text { Acontecimento } \\
\text { Vivência social }\end{array}$ & $\tau$ \\
\hline
\end{tabular}




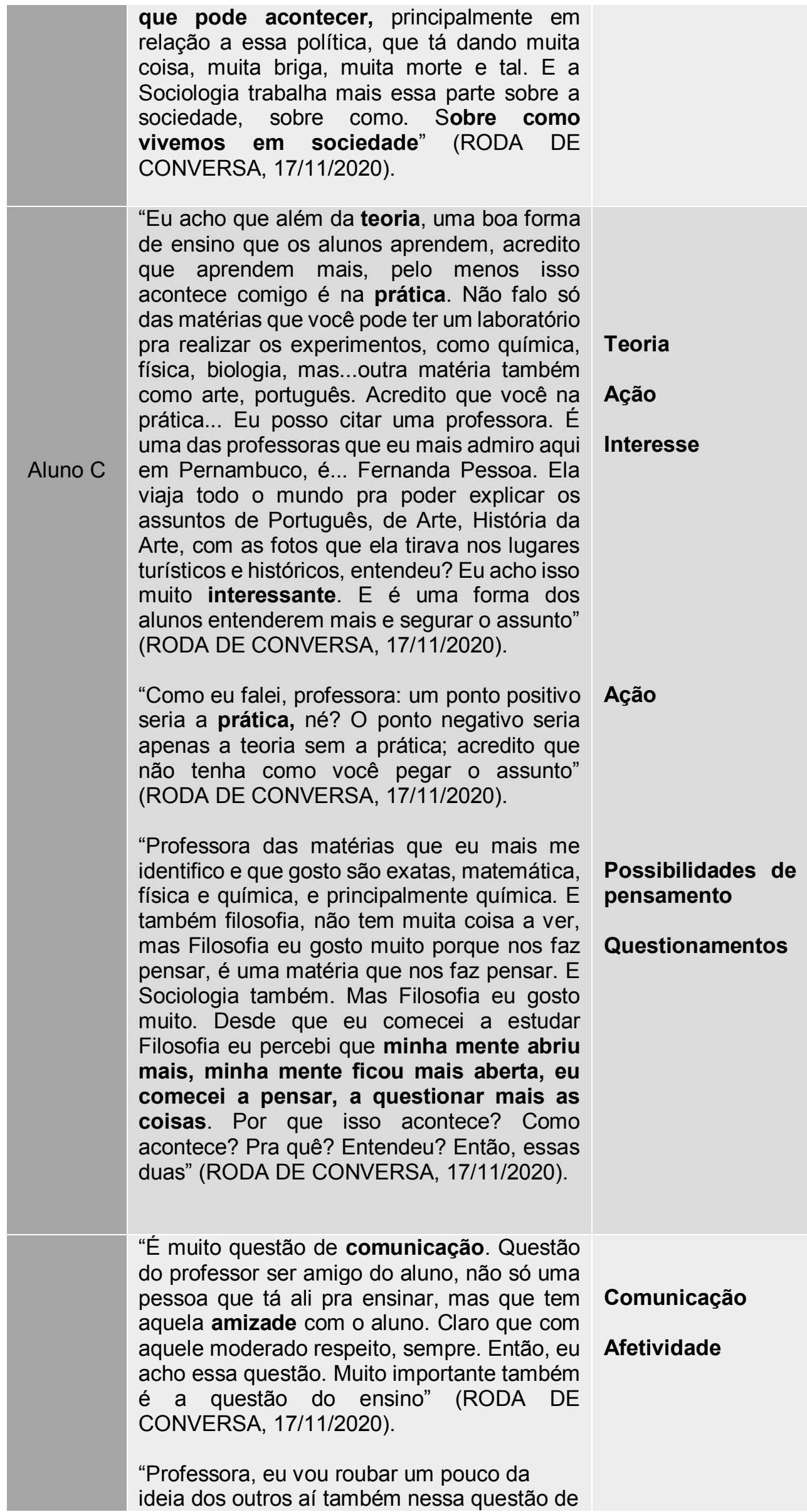




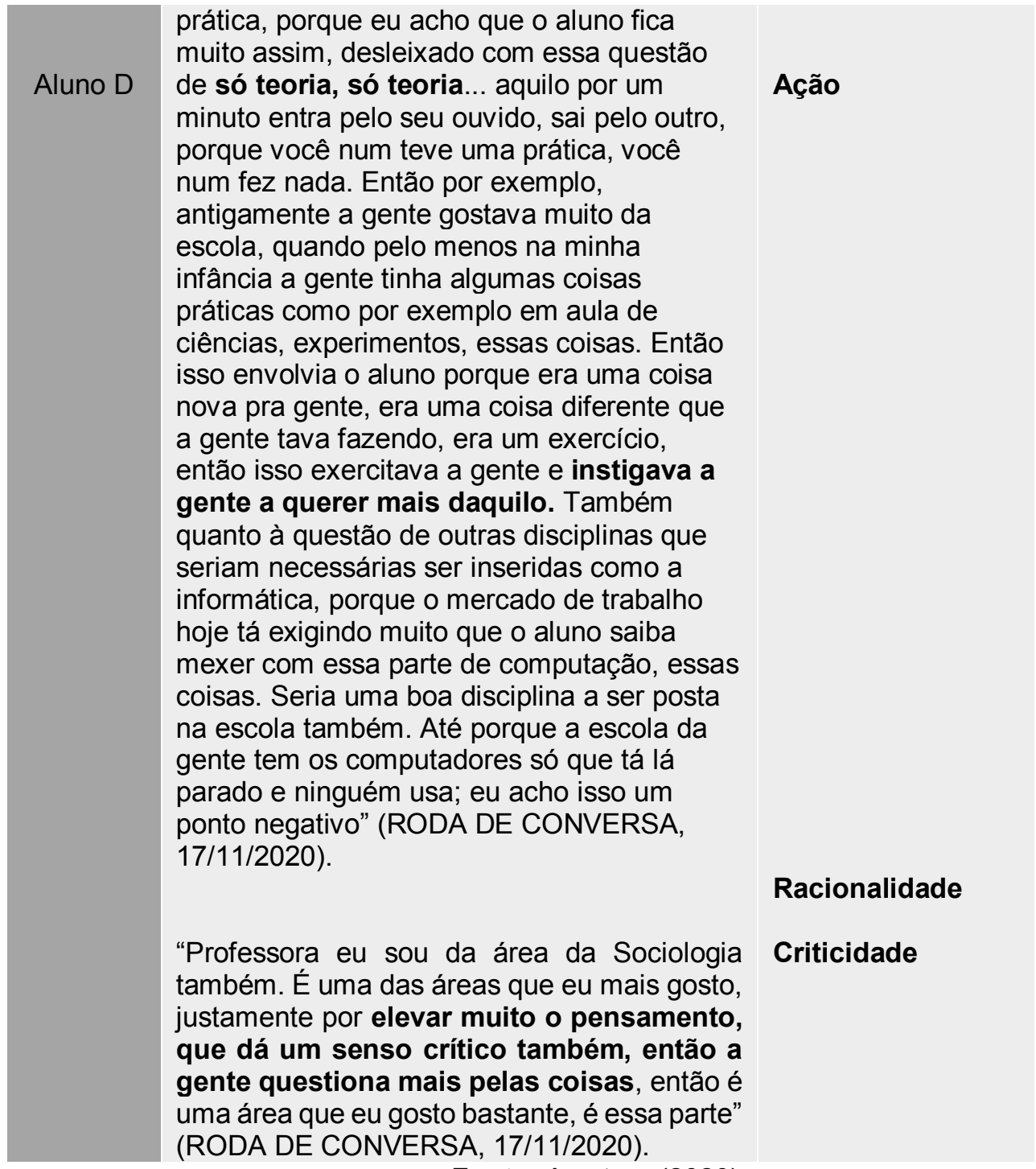

Fonte: A autora (2020).

As relações de poder expressas na imagem do professor como detentor de vastos conhecimentos para passar a informação para o educando e com ela um amontoado de concepções e reforçamento de condições perante o sujeito, materializam o ato de ensinar como sendo um processo de demonstração de poder. Torna-se em uma ferramenta de repetição da reafirmação de local social do ouvinte.

O despertar crítico do educando se faz através de uma postura presente e incisiva do educador. Isso reforça a ideia de que o sujeito é quem altera suas perspectivas em sociedade e sua realidade quando, principalmente, entende o seu estado presente e tenta verificá-la, compreendê-la. A tecnologia vem como um apoio, permitindo uma maior observação e compreensão, seja dos aspectos na sociedade a qual pertence ou outras realidades e outras formas sociais de existir. Para isso, a 
identificação com certas áreas do conhecimento sinaliza para os processos de constituição social do sujeito. Afirmam os estudantes:

\section{Quadro 11 - Aparelhamento digital e aprendizagem}

\begin{tabular}{|c|c|c|c|}
\hline SUJEITO & DISCURSO & $\begin{array}{l}\text { UNIDADE(S) DE } \\
\text { ANÁLISE }\end{array}$ & CAMPO \\
\hline Aluno $\mathrm{A}$ & $\begin{array}{l}\text { "Porque quando a gente tá de frente a tela do } \\
\text { celular, sempre tem alguma coisa pra tirar } \\
\text { nosso foco, aí eu não consigo aprender nada" } \\
\text { (RODA DE CONVERSA, 17/11/2020). } \\
\text { "A internet é, na aprendizagem, na maioria } \\
\text { das vezes, boa, mas tem gente que não tem } \\
\text { condições de ter um aparelho celular pra } \\
\text { poder estudar, aí complica mais a situação. } \\
\text { Pra quem tem condições de te um } \\
\text { aparelho, a internet ajuda bastante na } \\
\text { aprendizagem" (RODA DE CONVERSA, } \\
\text { 17/11/2020). } \\
\text { "O ruim disso tudo também é porque como a } \\
\text { aluna B falou, muita gente acabou se } \\
\text { acomodando nisso, e tipo ... ah eu vou } \\
\text { procurar tal questão que eu não tô } \\
\text { entendendo, eu não tô achando resposta, não } \\
\text { tô tendo contato com o professor... muita } \\
\text { gente se acomodou nisso, de ir lá e procurar } \\
\text { a resposta, de não saber o porquê daquela } \\
\text { resposta, de não saber qual a importância } \\
\text { daquilo. Só pegou e... como diz... copia e cola, } \\
\text { foi só uma cópia e cola. Não procurou saber } \\
\text { pra tirar a dúvida, pra saber o porquê } \\
\text { daquela resposta. Muita gente se acomodou } \\
\text { nisso" (RODA DE CONVERSA, 17/11/2020). }\end{array}$ & $\begin{array}{l}\text { Fonte } \\
\text { informação }\end{array}$ & $\frac{2}{\mathbf{U}}$ \\
\hline Aluna B & $\begin{array}{l}\text { "Tipo assim quando a gente tá usando } \\
\text { celular, tipo computador essas coisas a } \\
\text { gente diz que aprende, mas não aprende } \\
\text { porque o foco ele muda, e quando se está em } \\
\text { escola presencial ou algum cursinho tal você } \\
\text { aprende bem mais porque seu foco vai ser só } \\
\text { aquilo, seu foco vai ser só estudar. Você no } \\
\text { celular tá lá assistindo, tá lá estudando tal, } \\
\text { alguém manda uma mensagem, manda } \\
\text { vídeo, você vai ver, desconcentra. Você tá } \\
\text { em casa, alguém lhe chama, você já } \\
\text { desconcentra, chega alguém atrapalha. Então } \\
\text { acho que por rede social, por ensino } \\
\text { tecnológico é mais difícil, essa questão de } \\
\text { ensino virtual" (RODA DE CONVERSA, } \\
17 / 11 / 2020 \text { ). } \\
\text { poh professora, eu falei tipo assim que não dá } \\
\text { pra aprender em casa no sentido de que tipo, } \\
\text { certo, muita gente consegue aprender porque }\end{array}$ & $\begin{array}{l}\text { Interface digital } \\
\text { Ensino } \\
\text { Tecnologia } \\
\text { Virtualidades }\end{array}$ & \\
\hline
\end{tabular}


a casa é silenciosa, na casa só tem ele e os pais, ou não tem outra responsabilidade, tipo não tem muita coisa pra fazer ou até mesmo, mesmo fazendo uma rotina de estudos pra estudar em casa, naquele horário em que você tá estudando, ninguém lhe atrapalha, ninguém tipo, Ihe atrapalha de nenhuma forma, nem Ihe mandando mensagem, nem Ihe chamando pra nada. Mais em uma casa que você tem em torno de 9 pessoas, oito por aí, e essas oito pessoas são crianças, eu vejo que é bem difícil ter um ensino online, porque tipo assim, aqui em casa é tem... digamos que oito, nove crianças e o que são cinco ou é seis adultos. Então quando é nessa questão de ensino online é bem difícil estudar, até porque as crianças só vivem conversando, fazendo zoada, correndo e tal... e pra ter um momento assim só, ter um silêncio é bem difícil" (RODA DE CONVERSA, 17/11/2020).

"É... então, a tecnologia ela, principalmente agora, ela se tornou muito presente e muito importante pra gente. Apesar de que ela também pode ser, digamos que muito ruim... tipo ela nos prejudica muito porque - de certa forma ajuda quando a gente tem dúvidas, ela nos faz... tipo ela nos dá o mundo - também nos tira, porque tem o sentido de que a gente tem uma dúvida vai lá e tira, não tem o professor a gente vai lá, tenta se esforçar, tenta aprender, faz alguma coisa, faz o possível e o impossível dentro da internet, porque ela nos dá isso. Mas, ela também pode nos tirar em questão de segundos, porque ali se torna um vício, tipo, o professor passa uma atividade, você tem dúvida em alguma pergunta, vai lá e tenta pedir ajuda sobre aquela pergunta no Google, e ele vai lá e te dá a resposta... e se você for olhar a resposta e não for tirar a dúvida que você tinha, você vai ficar com aquele vício de ao invés de você chegar e tirar sua dúvida você vai querer só botar a pergunta lá e responder do jeito que tiver lá, você vai ficar com isso, vai deixar, como é o nome... sedentário e não vai deixar estudar, digamos assim... tem seu lado bom e tem seu lado ruim. Também nessa questão de muitas pessoas não terem uma tecnologia, não terem um acesso pra fazerem o mesmo tipo de pesquisa e a mesma qualidade de vida que eu, tipo, eu na internet tenho uma alta qualidade de vida nesse sentido, de poder pesquisar o que eu quiser, a hora que eu quiser e do jeito que eu quiser. $E$ outras pessoas não têm essa vantagem, estão em desvantagem por isso. É tanto eu ano que vem muita coisa e muita gente vai se prejudicar, pela tecnologia" (RODA DE CONVERSA, 17/11/2020).

\section{Ensino online}

Rotina

tecnológica

\section{Rapidez}

Inércia

Classe social 


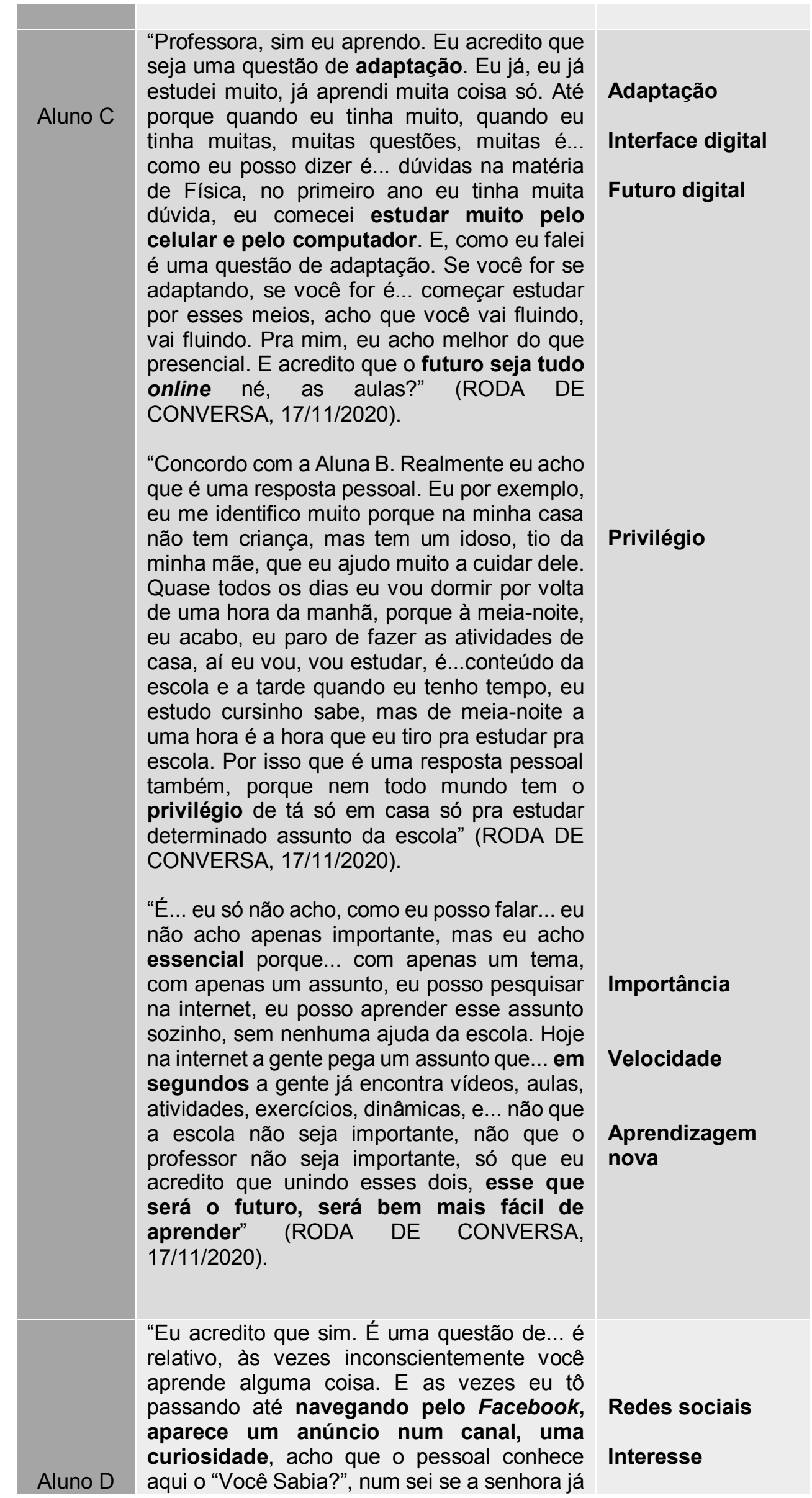




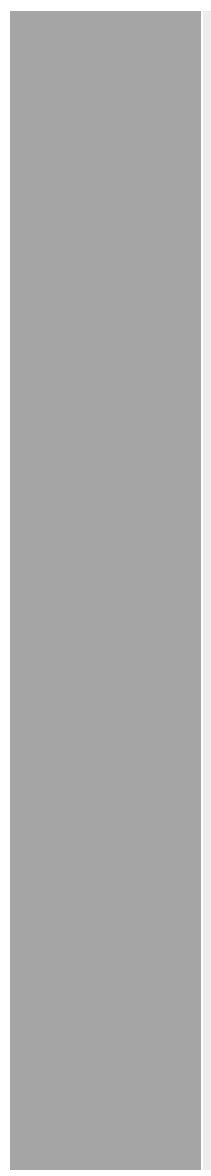

ouviu falar desse canal...É um canal que ele ensina muitas coisas assim... então às vezes ele aparece assim como anúncio no Facebook, as vezes você tá passando, para lá, e eles começam a ensinar algumas coisas que são curiosidades, algumas coisas que dá pra gente aprender por rede social" (RODA DE CONVERSA, 17/11/2020).

"Eu acho muito importante essa questão da tecnologia e o Ensino Médio andarem juntos, conciliados. Até porque, novamente, batendo na tecla, seria muito importante as aulas de informática, porque prepara o aluno pra o mercado de trabalho, tanto pra trabalhar em empresas, como autonomamente, que hoje em dia a gente utiliza bastante da tecnologia pra fazer os trabalhos. Então a escola já seria ali o preparo, o pontapé inicial pra o aluno dá início nessa área. Então eu acho muito importante que tenha isso. Mas, claro com aquele cuidado, porque às vezes a tecnologia dentro da escola pode atrapalhar em questão de atenção. Muitos alunos, às vezes, querem usar a tecnologia, mas de forma errada dentro da escola. Então isso seria uma preocupação a ser tomada" (RODA DE CONVERSA, 17/11/2020).

\author{
Ensino Médio \\ Tecnologia \\ Tecnologia na \\ escola
}

Fonte: A autora (2020).

As tecnologias vêm como ferramenta para mudar a posição do sujeito educando: de um simples ser-receptor e ser-repetidor de informação, tem agora que se moldar a si mesmo, mesmo que de forma difícil e com grandes entraves, em um ser-pesquisador. Se este deseja quebrar com a repetição de estruturas com a reafirmação de poderes, deverá ter novas conjecturas de pesquisa, isto sendo facilitado pelo emprego das tecnologias (MERCADO, 2002). Contudo, essa passagem de um sujeito que apenas recebe informação para aquele que pesquisa e também produz conhecimento, demanda habilidades e competências próprias para tal. $\mathrm{O}$ processo de ensino deveria ser voltado para a aquisição e desenvolvimento de tais habilidades e competências. Isso nos leva a compreender como os estudantes, quando questionados sobre como percebem as redes sociais e os aparelhos digitais frente à aprendizagem, vão se constituindo enquanto novos sujeitos que potencializam novas relações sociais.

Por fim, temos um apontamento e engajamento mais decisivo nas tecnologias; seja de forma virtual, nas redes sociais, seja de forma física, nos aparelhos digitais e computadores com acesso à internet. Percebemos, até o momento, as ideias e 
abstrações a respeito da ferramenta internet, como um espaço onde se está presente toda a informação que é possível acessar, bem como a percepção da sociedade mutante.

Esta urge por uma mudança no processo de ensino: demanda que se adapte às realidades de querer a informação naquele momento, utilizando-a enquanto é necessária e seguir para próxima, deixando a anterior. Nesse processo, indivíduos terminam por se perder nessas utilizações e se prendem tanto à urgência do saber, como terminam repetindo incessantemente ações impensadas e imediatas. Nessa trama de debate está a íntima ação de fazer o educador um ser capaz de quebrar com regras sociais e repetições, torná-lo um ser pensante por si só e capacitado à abstração de conceitos (MERCADO, 2002).

Verificamos assim, a preocupação dos estudantes em se ter uma posição crítica frente às tecnologias digitais da informação e comunicação. Se por um lado elas podem ser ferramentas para o desenvolvimento humano e a qualidade de vida, por outro, elas podem alienar o sujeito de sua própria realidade e anuviar suas potencialidades. É interessante também como alguns colocam o acesso à internet e às tecnologias como questão que contribui para a desigualdade social. Esse discurso revela as questões mais obscuras que podem estar sendo mascaradas na ideia de democratização e inclusão. Chegamos a questionar, então: incluímos digitalmente para quê? Para quem incluímos digitalmente? A quem serve as tecnologias digitais da informação e da comunicação, bem como as redes sociais?

Esse cenário crítico esboçado nos discursos e nas interações entre os estudantes nos leva a conhecer outro lado: o que pensam os professores acerca das tecnologias digitais da informação e comunicação frente à aprendizagem? Apresentaremos assim, um quadro com dados referentes à aplicação de questionário com professores. Optamos pelo quadro para facilitar a visualização dos dados e, em seguida, realizamos uma análise crítica dos discursos presentes na mensagem passada pelos sujeitos participantes. 


\section{Quadro 12 - Questionário aplicado aos professores}

\begin{tabular}{|c|c|c|c|}
\hline & Sujeito 1 & Sujeito 2 & Sujeito 3 \\
\hline IDADE & 36 & 28 & 41 \\
\hline FORMAÇÃO & Especialização & Especialização & Especialização \\
\hline ÁREA & $\begin{array}{l}\text { Formação pedagógica } \\
\text { em Matemática }\end{array}$ & $\begin{array}{l}\text { Licenciatura em } \\
\text { Matemática }\end{array}$ & Biologia \\
\hline ANO & 2019 & 2016 & 2001 \\
\hline Pós-Graduação & $\begin{array}{l}\text { Segurança do } \\
\text { Trabalho }\end{array}$ & Matemática & Biologia \\
\hline Tempo de experiência & 6 anos & 5 anos & 14 anos \\
\hline Formação profissional & $\begin{array}{l}\text { Comecei dando aula } \\
\text { de Ciências e } \\
\text { Matemática em escola } \\
\text { da rede municipal, } \\
\text { porém era formada } \\
\text { em outra área fui } \\
\text { gostando de ministrar } \\
\text { aula passar meus } \\
\text { conhecimentos foi ai } \\
\text { que resolvi fazer } \\
\text { licenciatura plena é } \\
\text { cursos na área de } \\
\text { educação. }\end{array}$ & $\begin{array}{l}\text { A decisão pela } \\
\text { docência iniciou } \\
\text { desde o ensino } \\
\text { fundamental } \\
\text { quando admirava } \\
\text { meus professores } \\
\text { pelo cuidado com } \\
\text { os alunos, pela } \\
\text { persistência pelo } \\
\text { ensino- } \\
\text { aprendizagem dos } \\
\text { alunos. Quando } \\
\text { terminei o ensino } \\
\text { médio, iniciei o } \\
\text { normal médio } \\
\text { (antigo magistério) } \\
\text { foi dando mais } \\
\text { certeza e admiração } \\
\text { por essa profissão. } \\
\text { Em seguida veio a } \\
\text { faculdade, os } \\
\text { estágios, os } \\
\text { projetos com isso } \\
\text { evidenciou mais } \\
\text { ainda que estava no } \\
\text { caminho certo. Hoje } \\
\text { em sala de aula } \\
\text { mesmo com } \\
\text { dificuldades e as } \\
\text { lutas. Sei que só } \\
\text { através da } \\
\text { educação que } \\
\text { podemos mudar o } \\
\text { mundo. }\end{array}$ & $\begin{array}{l}\text { Quando fiz a } \\
\text { faculdade era a } \\
\text { única opção, pois } \\
\text { só havia } \\
\text { licenciatura na } \\
\text { minha cidade. } \\
\text { Então, acabei } \\
\text { fazendo e aos } \\
\text { poucos fui } \\
\text { gostando do } \\
\text { magistério e da } \\
\text { educação }\end{array}$ \\
\hline $\begin{array}{l}\text { Em sua formação } \\
\text { inicial você estudou } \\
\text { sobre as Tecnologias } \\
\text { Digitais da Informação } \\
\text { e Comunicação? }\end{array}$ & $\begin{array}{l}\text { Pouco... quase não foi } \\
\text { abordado esse tema, } \\
\text { na verdade já existe } \\
\text { há muitos anos, } \\
\text { porém nem todo } \\
\text { mundo tem essa } \\
\text { praticidade com } \\
\text { tecnologia. }\end{array}$ & Sim. & Não. \\
\hline
\end{tabular}




\begin{tabular}{|c|c|c|c|}
\hline $\begin{array}{c}\text { O que você entende } \\
\text { por Tecnologias } \\
\text { Digitais da Informação } \\
\text { e Comunicação? }\end{array}$ & $\begin{array}{l}\text { São recursos de } \\
\text { computação que } \\
\text { visam agilidade e } \\
\text { armazenamento, } \\
\text { transmissão e acesso } \\
\text { rápido na segurança e } \\
\text { o uso das } \\
\text { informações... }\end{array}$ & $\begin{array}{l}\text { As tecnologias } \\
\text { contemporâneas } \\
\text { ligadas diretamente } \\
\text { na informação e } \\
\text { comunicação, pois } \\
\text { esses recursos são } \\
\text { atrativos na atuação } \\
\text { da aprendizagem. }\end{array}$ & $\begin{array}{l}\text { Entendo como a } \\
\text { utilização de } \\
\text { computadores, } \\
\text { celulares, ou } \\
\text { qualquer outro } \\
\text { tipo de } \\
\text { equipamento } \\
\text { digital que possa } \\
\text { transmitir } \\
\text { informação com a } \\
\text { utilização de } \\
\text { programas, } \\
\text { aplicativos via } \\
\text { internet. }\end{array}$ \\
\hline $\begin{array}{c}\text { Em seu trabalho, você } \\
\text { utiliza as Tecnologias } \\
\text { Digitais da Informação } \\
\text { e Comunicação? De } \\
\text { que modo? }\end{array}$ & $\begin{array}{l}\text { Sim! Uso o celular, o } \\
\text { computador para } \\
\text { fazer atividades, } \\
\text { gravar vídeos-aula e } \\
\text { conversar com os } \\
\text { alunos, seja de forma } \\
\text { ao vivo ou por } \\
\text { mensagens. }\end{array}$ & $\begin{array}{l}\text { Sim. Na } \\
\text { comunicação com } \\
\text { os alunos, na } \\
\text { divulgação de } \\
\text { projetos }\end{array}$ & $\begin{array}{l}\text { Sim. Através de } \\
\text { computadores, } \\
\text { celulares e } \\
\text { aplicativos com } \\
\text { WhatsApp e } \\
\text { Google sala de } \\
\text { aula. }\end{array}$ \\
\hline $\begin{array}{c}\text { Em sua escola, como } \\
\text { é a relação } \\
\text { pedagógica com as } \\
\text { Tecnologias Digitais } \\
\text { da Informação e } \\
\text { Comunicação? }\end{array}$ & $\begin{array}{l}\text { É boa tem muita } \\
\text { gente que sabe bem } \\
\text { os recursos e outros } \\
\text { estão em fase nova, } \\
\text { fase de } \\
\text { aprendizagem... }\end{array}$ & $\begin{array}{l}\text { Esses recursos } \\
\text { possibilitam uma } \\
\text { prática educativa no } \\
\text { ambiente escolar. } \\
\text { Um papel } \\
\text { importante na } \\
\text { difusão da } \\
\text { tecnologia e na } \\
\text { comunicação } \\
\text { coletiva. Com isso } \\
\text { os docentes podem } \\
\text { aproximar o } \\
\text { conteúdo explicado } \\
\text { com a vida do } \\
\text { discente. No } \\
\text { momento atual } \\
\text { (pandemia) toda } \\
\text { escola se } \\
\text { reinventou para } \\
\text { melhor efetivar o } \\
\text { conteúdo no } \\
\text { conhecimento do } \\
\text { alunos } \\
\text { evidenciando assim } \\
\text { que a TICs está } \\
\text { ligada à didática da } \\
\text { escola. }\end{array}$ & $\begin{array}{l}\text { Necessária, uma } \\
\text { vez que nesse } \\
\text { momento de } \\
\text { pandemia seria } \\
\text { impossível } \\
\text { transmitir } \\
\text { conhecimento } \\
\text { sem as } \\
\text { tecnologias de } \\
\text { informação. }\end{array}$ \\
\hline $\begin{array}{l}\text { Você tem redes } \\
\text { sociais? Conte-nos } \\
\text { sobre sua experiência } \\
\text { com as redes sociais }\end{array}$ & $\begin{array}{l}\text { Sim! Gosto de me } \\
\text { atualizar nas notícias, } \\
\text { saber de cursos em } \\
\text { educação tudo o que }\end{array}$ & $\begin{array}{l}\text { Sim. As redes } \\
\text { sociais no campo } \\
\text { profissional divulgo } \\
\text { meus trabalhos e }\end{array}$ & $\begin{array}{l}\text { Sim. Estressante, } \\
\text { pois tivemos que } \\
\text { dispor de meios } \\
\text { pessoais para dá }\end{array}$ \\
\hline
\end{tabular}




\begin{tabular}{|c|c|c|c|}
\hline $\begin{array}{c}\text { no seu cotidiano } \\
\text { profissional e pessoal. }\end{array}$ & $\begin{array}{l}\text { for proveitoso na } \\
\text { minha área } \\
\text { profissional... }\end{array}$ & $\begin{array}{l}\text { para comunicação } \\
\text { com os profissional } \\
\text { e discentes da } \\
\text { instituição. }\end{array}$ & $\begin{array}{l}\text { conta do ensino } \\
\text { aprendizagem } \\
\text { dos nossos } \\
\text { estudantes. }\end{array}$ \\
\hline $\begin{array}{c}\text { Você utiliza alguma } \\
\text { rede social para } \\
\text { dinamizar o seu } \\
\text { trabalho? Conte-nos } \\
\text { um pouco. }\end{array}$ & $\begin{array}{l}\text { Não! Rede social é } \\
\text { algo muito privado. }\end{array}$ & $\begin{array}{l}\text { Sim. Na divulgação } \\
\text { de projetos } \\
\text { mostrando a } \\
\text { participação dos } \\
\text { alunos e de datas } \\
\text { comemorativas } \\
\text { relacionada à } \\
\text { escola. }\end{array}$ & $\begin{array}{l}\text { Sim. Apenas o } \\
\text { WhatsApp. }\end{array}$ \\
\hline $\begin{array}{c}\text { O que você percebe } \\
\text { sobre a relação } \\
\text { dos(as) estudantes } \\
\text { com as redes sociais } \\
\text { na escola? }\end{array}$ & $\begin{array}{l}\text { Muitas vezes a } \\
\text { tecnologia atrapalha } \\
\text { porque eles levam o } \\
\text { celular para a escola } \\
\text { e não se concentram, } \\
\text { e ficam acessando as } \\
\text { redes sociais. }\end{array}$ & $\begin{array}{l}\text { Preocupante, pois } \\
\text { gastam muito tempo } \\
\text { no "mundo virtual" e } \\
\text { esquece de viver } \\
\text { seu "mundo real", } \\
\text { visto que as redes } \\
\text { sociais podem } \\
\text { influenciar na vida } \\
\text { desses estudantes, } \\
\text { seja de forma } \\
\text { positiva ou de forma } \\
\text { negativa. }\end{array}$ & $\begin{array}{l}\text { Que os mesmos } \\
\text { utilizam de forma } \\
\text { inadequada as } \\
\text { redes sociais, } \\
\text { muitas vezes } \\
\text { expondo suas } \\
\text { vidas pessoais, e } \\
\text { o pior, } \\
\text { espalhando em } \\
\text { algumas } \\
\text { situações, fake } \\
\text { news. }\end{array}$ \\
\hline $\begin{array}{l}\text { Como você avalia a } \\
\text { relação dos(as) } \\
\text { estudantes com os } \\
\text { aparelhos digitais } \\
\text { (celular, tablet, } \\
\text { notebook e outros)? }\end{array}$ & $\begin{array}{l}\text { Eles aprendem } \\
\text { rápido: são ágeis e } \\
\text { sabem se comunicar } \\
\text { bem, muitos ensinam } \\
\text { aos professores na } \\
\text { sala e ajudam os } \\
\text { colegas e assim eles } \\
\text { ficam cada dia mais } \\
\text { inteligentes... Os } \\
\text { alunos precisam estar } \\
\text { cientes desses } \\
\text { aparatos tecnológicos } \\
\text { e entenderem que são } \\
\text { mecanismos de } \\
\text { entretenimentos e } \\
\text { também de } \\
\text { aprendizagem e } \\
\text { socialização, mas não } \\
\text { substitui o contato } \\
\text { humano. }\end{array}$ & $\begin{array}{l}\text { Destaco que a } \\
\text { utilização desses } \\
\text { aparelhos digitais } \\
\text { quando auxiliado } \\
\text { pelo professor pode } \\
\text { ser uma ferramenta } \\
\text { de aprendizagem } \\
\text { na construção de } \\
\text { conhecimento dos } \\
\text { discentes. }\end{array}$ & $\begin{array}{l}\text { Péssima. Só } \\
\text { sabem manusear } \\
\text { o WhatsApp, } \\
\text { Instagram, } \\
\text { demostrando } \\
\text { pouco } \\
\text { conhecimento } \\
\text { sobre outros } \\
\text { aplicativos, o que } \\
\text { dificultou bastante } \\
\text { o ensino } \\
\text { aprendizagem. }\end{array}$ \\
\hline $\begin{array}{l}\text { Você acredita que as } \\
\text { Tecnologias Digitais } \\
\text { da Informação e } \\
\text { Comunicação (redes } \\
\text { sociais e aparelhos } \\
\text { digitais) têm gerado } \\
\text { novas formas de } \\
\text { socialização entre }\end{array}$ & $\begin{array}{l}\text { Sim! Eles se } \\
\text { comunicam entre si } \\
\text { tiram dúvidas sobre } \\
\text { matérias ou } \\
\text { atividades, com isso } \\
\text { acabam criando uma } \\
\text { rede de amizades } \\
\text { entre os estudantes. }\end{array}$ & $\begin{array}{l}\text { As TICs } \\
\text { aproximaram os } \\
\text { discentes seja na } \\
\text { comunicação como } \\
\text { na troca de } \\
\text { informação, } \\
\text { facilitando assim a }\end{array}$ & $\begin{array}{l}\text { Sim. Nesse } \\
\text { período de } \\
\text { pandemia tornou- } \\
\text { se essencial esse } \\
\text { tipo de } \\
\text { comunicação }\end{array}$ \\
\hline
\end{tabular}




\begin{tabular}{|c|c|c|c|}
\hline $\begin{array}{l}\text { os(as) estudantes? } \\
\text { Conte-nos sua visão. }\end{array}$ & & $\begin{array}{l}\text { socialização entre } \\
\text { eles. }\end{array}$ & \\
\hline $\begin{array}{c}\text { Em sua compreensão, } \\
\text { como a escola se } \\
\text { organiza e se projeta } \\
\text { frente ao uso das } \\
\text { redes sociais e dos } \\
\text { aparelhos digitais no } \\
\text { ensino? }\end{array}$ & $\begin{array}{l}\text { O avanço tecnológico } \\
\text { invadiu a sociedade, e } \\
\text { a escola também } \\
\text { entrou nesse ramo. } \\
\text { Os estudantes estão } \\
\text { cada vez conectados } \\
\text { em busca do } \\
\text { processo de } \\
\text { aprendizagem. }\end{array}$ & $\begin{array}{l}\text { Na escola sempre } \\
\text { evidenciou as } \\
\text { tecnologias } \\
\text { presentes na sua } \\
\text { organização e na } \\
\text { projeção na era } \\
\text { digital. Com o } \\
\text { surgimento de } \\
\text { desafios com as } \\
\text { tecnologias a escola } \\
\text { constantemente } \\
\text { tenta inovar na sua } \\
\text { didática para } \\
\text { acompanhar a era } \\
\text { digital. As redes } \\
\text { sociais direcionam a } \\
\text { escola para } \\
\text { divulgação de } \\
\text { assuntos relevante } \\
\text { a todos que a } \\
\text { compõe, já os } \\
\text { aparelhos digitais } \\
\text { são vistos como } \\
\text { facilitadores na } \\
\text { organização e no } \\
\text { desenvolvimentos } \\
\text { educacional da } \\
\text { instituição. }\end{array}$ & $\begin{array}{l}\text { Com dificuldade, } \\
\text { uma vez que a } \\
\text { maioria das } \\
\text { escolas e } \\
\text { professores não } \\
\text { dispõe da } \\
\text { tecnologia e do } \\
\text { conhecimento } \\
\text { necessário. } \\
\text { Muitos são } \\
\text { analfabetos } \\
\text { digitais. }\end{array}$ \\
\hline $\begin{array}{c}\text { Imagine a escola, a } \\
\text { sociedade, as novas } \\
\text { juventudes, as redes } \\
\text { sociais e os aparelhos } \\
\text { digitais. Em apenas } \\
\text { uma imagem, como } \\
\text { você traduz essa } \\
\text { relação? }\end{array}$ & $\begin{array}{l}\text { Relação de } \\
\text { conhecimentos } \\
\text { atrelados uns ligados } \\
\text { aos outros } \\
\text { conectados cada um } \\
\text { passando } \\
\text { informações. }\end{array}$ & Interligação digital. & $\begin{array}{l}\text { Como um } \\
\text { ecossistema. }\end{array}$ \\
\hline $\begin{array}{l}\text { Você acredita que as } \\
\text { redes sociais e os } \\
\text { aparelhos digitais } \\
\text { estejam criando novas } \\
\text { formas de } \\
\text { subjetividade e novas } \\
\text { maneiras de socializar } \\
\text { dentro da escola? }\end{array}$ & $\begin{array}{l}\text { Sim! As pessoas } \\
\text { passam a se } \\
\text { socializar cada vez } \\
\text { mais, em busca de } \\
\text { novos desafios. }\end{array}$ & Sim. & Sim. \\
\hline $\begin{array}{c}\text { Como seriam essas } \\
\text { novas subjetividades }\end{array}$ & $\begin{array}{l}\text { A forma interessante } \\
\text { da tecnologia na } \\
\text { sociabilização entre }\end{array}$ & $\begin{array}{l}\text { As novas } \\
\text { subjetividade está } \\
\text { relacionada }\end{array}$ & $\begin{array}{l}\text { Através da } \\
\text { comunicação e }\end{array}$ \\
\hline
\end{tabular}




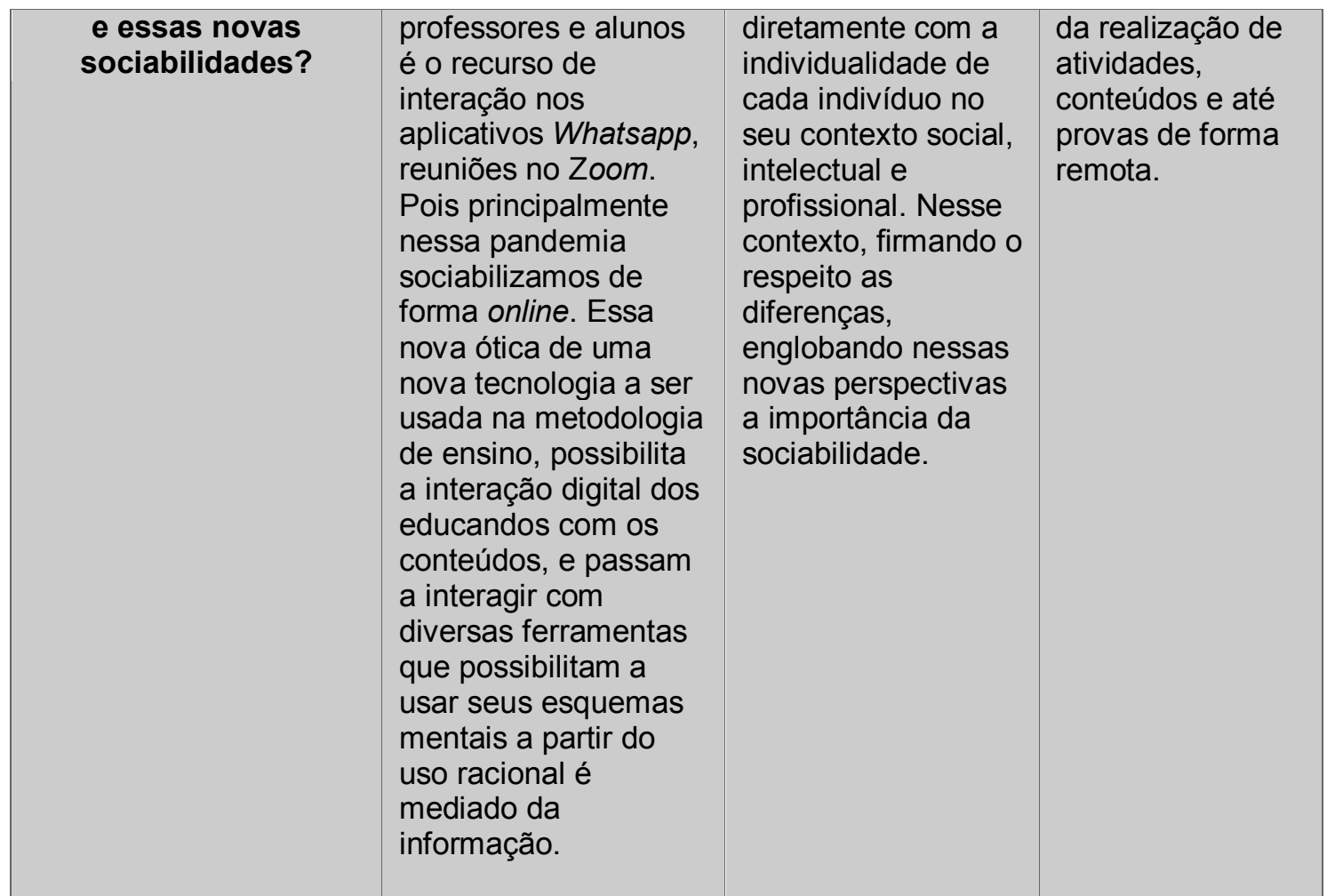

Fonte: A autora (2020).

O que os professores trazem para discussão repercute bastante no apresentado pelos alunos, já que o educador serve de exemplo para o estudante. Pegar-se-á por cada tópico para se entender como se deu a formação de cada sujeito e seus reflexos na formação dos estudantes.

De início se tem a informação sobre suas práticas e formações. Verifica-se que tiveram uma formação mais voltada na passagem de conteúdo, de informações, mesmo isso sendo de grande importância na atualidade, preza-se pela formação do educando com a perspectiva de que este, ao buscar o conhecimento, saiba o que fazer e como utilizar tais ideias.

Na pós-modernidade, para mantermos enfrentamentos aos valores de descarte e de fluidez, na educação precisamos evidenciar uma formação crítica da cidadania. Como orienta Bauman (2017, p. 50), a constituição do sujeito crítico, deve considerar que "o outro lado da individualização parece ser a corrosão e a lenta desintegração da cidadania". Assim, os interesses individuais não devem sobrepor os interesses públicos, sendo essa abordagem um elemento da formação humana crítica.

$\mathrm{Na}$ questão seguinte (Em sua formação inicial você estudou sobre as Tecnologias Digitais da Informação e Comunicação?), já se percebe como o estudo referente à formação profissional só começou a abordar a aplicação das novas 
tecnologias recentemente. Isso gera um grande precedente, principalmente quando não se tem uma atualização dos profissionais mais intensa e eficaz (PORCHEDDU, 2009). Nesse sentido,

A ideia de que a pedagogia também possa ser um "produto" destinado à apropriação e à conservação, é uma ideia desagradável e contrária à pedagogia institucionalizada. Para convencer as crianças da importância do conhecimento e do uso da aprendizagem, os pais de antigamente lhes diziam que "ninguém nunca poderá roubar a sua cultura"; o que soava como uma promessa encorajadora para os filhos de então, seria uma horrenda perspectiva para os jovens de hoje. Os compromissos tendem a ser evitados, a menos que venham acompanhados de uma cláusula de "até nova ordem" (PORCHEDDU, 2009, p. 663).

Dentro da discussão, se percebe muito os impactos causados pela implementação das TDIC na escola e, principalmente, na sala de aula. Ainda mais atualmente, devido à situação mundial com a pandemia da Covid-19. Nesse contexto se tem a verificação dos próprios professores ao perceber como os estudantes, mesmo sabendo como lidar com as tecnologias ou as informações, se perdem na utilização destes sob a forma de ferramentas (MOREIRA, 2015).

Em seguida vemos como os principais profissionais que lidam com os indivíduos mais jovens, que estão construindo sua formação enquanto sujeitos, percebem suas principais formas de se relacionar com outros sujeitos. Como bem relatado, notaram as novas formas que lidam com as interações nas redes sociais; constataram, no entanto, como no início da globalização houve a facilitação em adquirir novos aparelhos eletrônicos e como essas interações foram modificadas. Até certo ponto foram intensificadas devido à forma mais prática de se conhecer e se comunicar com outros sujeitos (LIMA, 2009; VEIGA-NETO, 2009; CASTELLS, 1999; SIMÕES, 2009).

Novos espaços e novas formas de interação foram geradas e adquiridas pelos sujeitos, mesmo sendo representações de espaços reais, as redes sociais se valem de regras de interação, determinando o que rege cada espaço. É a construção do próprio tecido social das redes sociais que elaboram seus sentidos, seus sujeitos e suas sociabilidades (PORCHEDDU, 2009; BOURDIEU, 2001). Assim,

A sociedade atual passa por profundas mudanças caraterizadas por uma profunda valorização da informação. Na chamada Sociedade da Informação, processos de aquisição do conhecimento assumem um papel de destaque e passam a exigir um profissional crítico, criativo, com capacidade de pensar, de aprende a aprender, de trabalhar em grupo e de se conhecer como indivíduo. Cabe a educação formar esse profissional e para isso, esta não se sustenta apenas na instrução que o professor para ao aluno, mas na 
construção do conhecimento pelo aluno e no desenvolvimento de novas competências, como: capacidade de inovar, criar o novo a partir do conhecido, adaptabilidade ao novo, criatividade, autonomia, comunicação. É função da escola, hoje, preparar os alunos para pensar, resolver problemas e responder rapidamente as mudanças contínuas (MERCADO, 2002, p. 1).

Uma discussão importante a ser feita é a forma como os próprios professores percebem que a instituição escolar precisa se atualizar, e como algumas já possuem uma perspectiva de como e o que pretendem atingir com as novas tecnologias utilizadas na melhora da aprendizagem do educando. Outras ainda têm dificuldades, seja com a falta de preparo dos educadores, seja com a estrutura escolar não pronta para a recepção de novas práticas de descoberta de informação e interações entre os indivíduos (PORCHEDDU, 2009; FRAGOSO, 2011).

Muito se precisa melhorar, mas o principal fator de aprimoramento será a construção da instituição escolar de modo crítico, que consiga repensar a educação sobre novas bases, novos pilares da sociedade moderna que estão em mudança constante e, acima de tudo, visando sempre o desenvolvimento das capacidades humanas e sociais, sempre tentando se respeitar o outro enquanto sujeito de convívio social. Assim, nos diz Lostada (2011, p. 401):

\footnotetext{
Nesse sentido, o ato educativo constitui-se em sua possibilidade como um ato de libertação, de racionalização, para o qual contribuem as chamadas Tecnologias da Informação e da Comunicação (TIC). Não se pode mais pensar que os recursos tecnológicos de que a sociedade dispõe não se aplicam aos processos educativos ou que a eles sejam destinados de maneira secundária, relativizada.
}

A educação enquanto ferramenta modificadora de instituições e modificada por estas, depende sempre da sociedade e das formas de interações entre os sujeitos, ou seja, ao modificar a sociedade a educação é modificada por ela, em um eterno ciclo. Ir contra essas ondas de modificações e atualizações só as tornam obsoletas, e em casos indesejadas, como ferramentas pelos indivíduos. 


\section{CONSIDERAÇÕES FINAIS}

A função social da escola gera uma discussão ampla, complexa e nunca acabada. Entretanto, nos interessou essa discussão sob a perspectiva sociológica. Mais ainda: apresentamos uma análise sociológica crítica sobre a escola e sua relação com as TDIC. Chamamos de sociologia das tecnologias digitais da informação e comunicação os estudos, as reflexões e as análises que tratam diretamente da relação das TDIC em seus diversos contextos.

Para deixarmos o fenômeno das TDIC no campo sociológico, estruturamos o estudo a partir de contribuições e de quadros teóricos como Bauman (2001), Bourdieu (2011) e Lévy (1998). Cada qual com suas percepções e reflexões sobre o tema, de modo indireto ou mais diretivo possível. Pensar em uma sociologia das tecnologias digitais da informação e comunicação nos pede uma posição conceitual e uma definição de pressupostos que orientaram e guiaram a pesquisa. Centramos, pois, nossa posição nos conceitos de pós-modernidade, cibercultura e função reprodutora da escola.

Assim, temos que a pós-modernidade é um tempo construído sob a emergência de necessidades sociais outras, que se fundamenta em valores responsáveis por estruturar as relações sociais e os modos de existir e de estar no mundo. Valores como individualismo elevado, urgência e imediatismo como maneiras de se relacionar, descarte como resposta às demandas necessárias e a própria existência enquanto consumo. É na pós-modernidade onde as referências institucionais foram se desfazendo. Tudo que de modo sólido guiou de modo seguro as relações sociais, agora se faz no ar. É a liquidez das instituições com sua dinâmica de mutabilidade, irregularidade e autorreferências.

Na pós-modernidade, o sujeito é outro: ele media sua experiência no mundo por meio da velocidade do que considera por verdade. Ele é regido pelo imediatismo, pela necessidade de usufruir cada vez mais daquilo que the é pertinente temporariamente. $O$ sujeito pós-moderno é mesmo um tipo social - não universal, mas que carrega suas ambiguidades, contradições e pluralidade - situado em um espaçotempo da descontinuidade, do descarte fácil e descomprometido.

Interessou-nos então, como esse sujeito, na escola, especificamente, ia guiando seu agir, sentir e pensar. Para isso, entendemos que esse sujeito media sua existência - em um mundo altamente digital, virtual e aparelhado de tecnologias - 
pelas interfaces digitais. A cibercultura é o espaço-tempo produtor das verdades e dos regimes de verdade, informação e validação social por onde circula os aspectos culturais virtualizados. Estar na cibercultura demanda ações e posições específicas, assim como um código de conduta que modela e padroniza a forma de ser e estar.

A cibercultura influencia, desse modo, os processos de subjetivação de sujeito na pós-modernidade. Isso requer uma lógica de cooptação de sujeitos que trafegam e transitam cotidianamente entre o real e o virtual, onde ambos os espaços são continuações, interligações e codependentes. Para que seja assim, há a necessidade de interfaces que coloquem o sujeito neste entre-lugar, nesta linha de transição, no limite entre um e outro. Ao ser transportado para esse entre-lugar, o sujeito vivencia e experimenta o mundo de modo singular, sendo regido por valores pós-modernos. Resulta nisso a forma como agirá e como atuará, socialmente, em suas relações.

Assim, pensamos que na escola, mais particularmente no Ensino Médio, há implicações para os processos de subjetivação, produção de conhecimento e mediação de mundo social. Desse modo, ao respondermos ao problema de pesquisa deste trabalho, a saber: quais as implicações do aparelhamento digital para o ensino de Sociologia no Ensino Médio?, estamos percebendo a necessidade de investigações sociológicas que contribuam para o desenvolvimento da área sociológica e, especialmente, para o ensino de sociologia, tão atacado em governos detratores da formação crítica.

A escola é uma instituição social que lida diretamente com subjetividades e intersubjetividades. Em jogo está a diferença, a constituição da diferença e os modos de identificação social e desidentificação. Isso quer dizer que temos em evidência estruturas que manipulam os arranjos sociais de poder, de controle e, de modo ambíguo, insurgências. Assim, temos a escola produzindo e reproduzindo situações sociais, perpetuando valores de determinado grupo e com determinados fins, mas temos também a escola provocando fissuras, desestabilizações e rompimentos.

Nitidamente, a centralidade docente é essencial para que a escola vá reproduzindo as situações sociais de controle ou que oportunize situações de emergência e insurgência. O cotidiano vai sendo fabricando, tecido, enfrentado, e assim vamos considerando a potencialidade social da escola em propor valores outros para além do descarte, do imediatismo e do individualismo exagerado.

A tecnologia passa a ser um fator decisivo para que os aspectos de reprodução ou de insurgência sejam operados na escola. De um lado temos que: 1) na pós- 
modernidade, o social é cerceado de tecnologias; 2) o sujeito pós-moderno deve, para ser incluído no social, usar ao máximo as tecnologias e 3) a tecnologia não é boa, nem má, estando livre de adjetivos. O uso que fazemos das tecnologias é que é político e tem um fim pedagógico.

Estando na escola jovens aparelhados digitalmente, eles passam a tecer suas subjetividades pelas experiências das TDIC e, em grande parte, das redes sociais. Esse aparelhamento digital é sua nova roupa social: é por ele que se acessa a si, ao outro e ao mundo. Inventam-se, portanto, modos outros de ser. Pensando no contexto das aulas de sociologia no Ensino Médio, há a mediação do conhecimento pelas interfaces digitais.

Percebemos que as aulas de sociologia são processos pedagógicos que oportunizam a formação crítica de pessoas. Essa formação é de emergências e enfrentamentos, de autoconhecimento e de posicionamentos. Por isso se tornam tão perigosas para aqueles que temem o poder de um sujeito crítico, indagador e que se coloca em processo de desnaturalizar o que é posto socialmente como normal, correto e verdadeiro.

Quando o aparelhamento digital é trazido para sala de aula como parte do convívio humano, como realidade pós-moderna da qual não podemos fugir, entendemos que o ensino de sociologia pode ser potencializado com interações mais cotidianos, com partilha de experiências mais pessoais com o social e possibilita a formação crítica por excelência. O ato de desnaturalizar as TDIC, que se desdobra de modo mais evidente nas redes sociais, é uma das principais consequências de aprender o social criticamente.

Importante lembrar que, como percebemos no estudo, parte dos professores que lecionam sociologia no ensino médio não têm formação adequada, vindo de outras licenciaturas. Sob esse ponto, não podemos nos aprofundar, por não ter sido elemento de investigação, mas acreditamos que há uma relação entre a qualidade das aulas de sociologia ministradas por professores formados em sociologia e aqueles que não são formados.

Políticas de formação de professores, de concursos públicos para ingresso na educação pública e também as diretrizes curriculares para formação de professores podem ser tensionadas para que novos estudos apontem novos caminhos. Por fim, questionamos como modo de manter nosso estudo inacabado: como pensar uma formação de professores de sociologia a partir do aparelhamento digital? Quais 
competências e habilidades são exigidas de professores de sociologia no contexto da pós-modernidade e das realidades do aparelhamento digital? O que a escola pode produzir como regime de táticas e enfrentamentos aos ataques que sofre o ensino de sociologia? 


\section{REFERÊNCIAS}

ALMEIDA, Dieiminy Machle de. A relevância do uso de tecnologias da informação no ensino de sociologia. In: LIMA, Angela Maria de Sousa; et al (org). Práticas e debates na formação de professores de sociologia/ciências sociais. Londrina: UEL, 2013.

BAKHTIN, Mikhail; VOLOCHÍNOV, Valentin. Marxismo e filosofia da linguagem. Problemas fundamentais do método sociológico na ciência da linguagem. $4^{\mathrm{a}}$ edição. Tradução por Michel Lahud e Yara Frateschi Vieira. São Paulo: Hucitec, 1988.

BAUMAN, Zigmunt. Modernidade líquida. Tradução de Plínio Dentzien. Rio de Janeiro: Zahar, 2001.

BAUMAN, Zigmunt. Tempos líquidos. Tradução de Carlos Alberto Medeiros. Rio de Janeiro: Zahar, 2007.

BAUMAN, Zigmunt. Vida líquida. Tradução de Carlos Alberto Medeiros. $2^{\mathrm{a}}$ ed. Rio de Janeiro: Zahar, 2009.

BAUMAN, Zygmunt. Amor líquido. Rio de Janeiro: Jorge Zahar, 2004.

BAUMAN, Zygmunt. Ética pós-moderna. São Paulo: Paulus, 1997.

BAUMAN, Zygmunt. O mal estar na pós modernidade. Rio de Janeiro: Zahar, 1998.

BECK, Ulrich. A reinvenção da política: rumo a uma teoria da modernização reflexiva. In: GIDDENS, A.; BECK, U.; LASH, S. (Orgs.). Modernização reflexiva. São Paulo: Unesp, 1997.

BECK, Ulrich; GIDDENS, Anthony; LASH, Scott. Modernização reflexiva. São Paulo: Editora da Unesp, 1995.

BECKER, Howard S. De que lado estamos? Uma teoria da ação coletiva. Rio de Janeiro: Zahar Editores, 1977.

BENJAMIN, Walter. Magia e técnica, arte e política. Ensaios sobre literatura e história da cultura. Obras escolhidas. Vol. 1. Tradução de Sérgio Paulo Rouanet. São Paulo: Brasiliense, 1987.

BENJAMIN, Walter. Sobre Arte, Técnica, Linguagem e Política. Lisboa: Relógio D' Água, 1992.

BONDÍA, Jorge Larrosa. Notas sobre a experiência e o saber de experiência.

Revista Brasileira de Educação [online], n. 19, pp. 20-28, 2002.

BOURDIEU, Pierre. Escritos de Educação. Petrópolis: Vozes, 1998.

BOURDIEU, Pierre. O Poder Simbólico. Rio de Janeiro: Editora Bertrand Brasil S.A, 1989. 
BOURDIEU, Pierre; CHAMBOREDON, Jean-Claude; PASSERON, Jean-Claude. A Profissão de Sociólogo. Preliminares epistemológicas. Trad. Guilherme João de Freitas Teixeira. Petrópolis: Vozes, 2000.

BRASIL. PCN Ensino Médio +. Orientações Educacionais Complementares aos Parâmetros Curriculares Nacionais. Ciências Humanas e suas tecnologias. Disponível em: http://www.cespe.unb.br/interacao/novo guia/CienciasHumanas.pdf. Acesso em 26 de maio de 2020.

BRASIL. Ministério da Educação, Secretaria de Educação Média e tecnológica. Parâmetros Curriculares Nacionais: Ensino Médio. Brasília: Ministério da Educação, 1999.

BUENO, Belmira Oliveira; ARNOLDI, Eliana Sacaravelli. Práticas de leitura e escrita de professoras em contextos de ensino semipresencial: novas maneiras de viver e estar na profissão docente. Zona Próxima, Barranquilla, n. 17, jul-dez/2012, Universidad del Norte Barranquilla, Colombia.

CALEGARI, Lizandro Carlos. Crítica da cultura, crítica da modernidade: a representação da literatura no século XX. Jundiai: Paco Editorial, 2016.

CALVINO, Manuel. Mesa de abertura. In: Conselho Federal de Psicologia (org.). Mídia e psicologia: produção de subjetividade e coletividade. $2^{a}$ ed. Brasília: Conselho Federal de Psicologia, 2009.

CASTELLS, Manuel. A sociedade em rede. A era da informação: economia, sociedade e cultura, Volume 1. São Paulo: Paz e Terra, 2000.

CASTELLS, Manuel. A era da informação: economia, sociedade e cultura. São Paulo: Paz e terra, 1999.

COELHO, Ana Lúcia de Araújo Lima. Construção do discurso da sustentabilidade: uma prática de Análise Sociológica do Discurso no campo organizacional. Tese. 266 f. Programa de Pós-Graduação em Administração. Universidade do Vale do Itajaí, Biguaçu, 2012.

CONDE, Fernando. Análisis sociológico del sistema de discursos. Cuadernos Metodológicos 43. Madrid: Centro de Investigaciones Sociológicas (CIS), 2009.

COSTA, Rogério da. A cultura digital. 3ª ed. São Paulo: Publifolha, 2008.

DELEUZE, Gilles e GUATTARI, Félix. O Anti-Édipo: capitalismo e esquizofrenia. Tradução Luiz Benedito Lacerda Orlandi. São Paulo: Editora 34, 2010.

DURKHEIM, Émile. As regras do método sociológico. $17^{\mathrm{a}}$ ed. São Paulo: Editora Nacional, 2002.

ERCILIA, Maria. A internet. São Paulo: Publicafolha, 2000.

FERREIRA, Norma Sandra de Almeida. As pesquisas denominadas "Estado da Arte". Educação \& Sociedade, ano XXIII, n. 79, ago/2002. 
FOUCAULT, Michel. História da sexualidade I: a vontade de saber. Rio de Janeiro: Edições Graal, 1988.

FOUCAULT, Michel. Iluminismo e crítica. Roma: Donzelli Editore, 1999.

FRAGOSO, Tiago de Oliveira. Modernidade líquida e liberdade consumidora: o pensamento crítico de Zygmunt Bauman. Perspectivas Sociais, Pelotas, n. 1, 2011.

FREIRE, Paulo. Conscientização: teoria e prática da libertação: uma introdução ao pensamento de Paulo Freire. Tradução de Kátia de Mello e Silva. São Paulo: Cortez \& Moraes, 1979.

FRIDMAN, Luis Carlos. Próximos ou separados? Ideias de Giddens e Bauman sobre as motivações para a política. Lua Nova [online], n 92. São Paulo, 2014.

FRIDMAN, Luis Carlos. Vertigens pós-modernas (Giddens, Touraine, Bauman). Lua nova [online], nº 47. São Paulo, agosto 1999.

GARRIDO, E. A técnica close e a compreensão da leitura: Investigação em textos de estudos sociais para a $6^{a}$ série. Dissertação de mestrado, USP. São Paulo, 1979.

GERALDI, João Wanderley. O texto na sala de aula. Cascavel: ASSOESTE, 1984.

GIDDENS, Anthony. As consequências da modernidade. São Paulo: Editora da Unesp, 1991.

GIDDENS, Anthony. Modernidade e identidade. Rio de Janeiro: Jorge Zahar, 2002.

GODOI, Chistiane Kleinübing; MASTELLA, Adriano Silveira; UCHÔA, Antônio Giovanni Figlioulo. Integração metodológica entre grupo de discussão e análise sociológica do discurso: um caso exemplificador sobre o discurso feminino acerca do consumo da beleza. Revista Eletrônica de Administração - READ, Porto Alegre, vol. 24, $\mathrm{n}^{\circ} 1,2018$.

GOFFMAN, Erving. Comportamento em lugares públicos. Petrópolis: Vozes, 2010.

GUIMARÃES, Elisabeth da Fonseca; ALVES, Elaine Gonçalves. Centro de Referência Virtual do professor - CRV: portal de apoio didático pedagógico para o professor de sociologia. Revista Brasileira de Sociologia, vol. 02, n. 03, janjun/2014.

HALL, Stuart. A identidade cultural na pós-modernidade. 9 $9^{\text {a. }}$ ed. Rio de Janeiro: DP\&A, 2004.

HALL, Stuart.; SILVA, Tomaz Tadeu da; WOODWARD, Kathryn. Identidade e diferença: a perspectiva dos estudos culturais. $4^{a}$ ed. Petrópolis: Vozes, 2000.

HARAWAY, Donna. Um manifesto para os cyborgs: ciência, tecnologia e feminismo socialista na década de 80. In: HOLLANDA, Heloisa Buarque. Tendências e impasses - o feminismo como crítica da cultura. Rio de Janeiro: Rocco, 1994. 
HARDT, Michael. A sociedade mundial de controle. In: ALLIEZ, Eric. Gilles Deleuze: uma vida filosófica. São Paulo: Editora 34, 2000.

IBÁÑEZ, Jésus. Como se realiza uma investigación mediante grupos de discusión. In: GARCÍA, M.; IBÁÑEZ, J.; ALVIRA, F. El análisis de la realidad social: métodos y técnicas de investigación. Madrid: Alianza, 1990.

IBÁÑEZ, Jesús. Perspectivas de la investigación social: el diseño en las tres perspectivas. In: GARCÍA, M.; IBÁÑEZ, J.; ALVIRA, F. (Org.). El análisis del realidad social: métodos y técnicas de investigación. Madrid: Alianza Editorial, 2010.

$\mathrm{KOCH}$, Ingedore Villaça; ELIAS, Vanda Maria. Ler e compreender: os sentidos do texto. $3^{a}$ edição. São Paulo: Contexto, 2010.

LEMOS, André.; CUNHA, Paulo. Olhares sobre a cibercultura. Porto Alegre: Sulina, 2003.

LEODORO, Silvana Aparecida Pires. A disciplina Sociologia no Ensino Médio: perspectivas de mediação pedagógica e tecnológica. Um diálogo possível.

Dissertação. 253 f. Programa de Pós-graduação em Educação, Universidade de São Paulo, São Paulo, 2009.

LÉVY, Pierre. A inteligência coletiva: por uma antropologia do ciberespaço. 8 ed. São Paulo: Edições Loyola, 2011.

LÉVY, Pierre. As tecnologias da inteligência. 2a ed. São Paulo: Editora 34, 2010.

LÉVY, Pierre. Cibercultura. 2ª ed. São Paulo: Editora 34, 2000.

LÉVY, Pierre. O que é o virtual? 2a ed. São Paulo: Editora 34, 2011.

LIMA, Maria Conceição Alves de. Ciberespaço, Cibercultura, Ciberescola:

Revisitando Pierre Lévy. ARTEFACTUM: Revista de estudos em Linguagens e Tecnologia, v. 4, n. 3, 2009.

LOSTADA, Lauro Roberto. A escola na formação do pensar através das mídias na perspectiva da teoria de Pierre Bourdieu. Poiésis-Revista do Programa de PósGraduação em Educação, v. 4, n. 8, 2011.

MARTINS NOGUEIRA, Cláudio Marques; NOGUEIRA, Maria Alice. A sociologia da educação de Pierre Bourdieu: Limites e contribuições. Revista Educação e Sociedade, Campinas, vol. 23, nº 78, 2002.

MARTINS, José; GONÇALVES, Ramiro; SANTOS, Vítor; COTA, Manuel Pérez; OLIVEIRA, Tiago; BRANCO, Frederico. Proposta de um Modelo de e-Learning Social. RISTI, n. 16, dez/2015.

MATTAR, Fauze Najib. Pesquisa de marketing. São Paulo: Atlas, 1994. 
MATTOS, Carmen Lúcia Guimarães. A abordagem etnográfica na investigação científica. Revista Espaço (INES), n. 16, p. 42-59, jul-dez. 2001.

MERCADO, Luiz Paulo Leopoldo. Novas tecnologias na educação: reflexões sobre a prática. - Maceió: EDUFAL, 2002

MILLS, Charles Wrigth. A Imaginação Sociológica. Rio de Janeiro, Ed. Zahar, 1969.

MINAYO, Maria Cecília de Souza (org). Pesquisa Social: Teoria, Método e Criatividade. 6ª edição. Petrópolis: Editora Vozes, 1996.

MISKOLCI, Richard. Sociologia Digital: notas sobre pesquisa na era da conectividade. Contemporânea-Revista de Sociologia da UFSCar, v. 6, n. 2, 2016.

MOCELIIM, Alan. Lugares, Não-Lugares, Lugares Virtuais. Revista Eletrônica dos Pós-Graduandos em Sociologia Política da UFSC, vol. 6, n. 3, 2009

MOCELIIM, Alan. Simmel e Bauman: modernidade e individualização. Em Tese, v. 4, n. 1, 2007.

MORAES, Amaury César de. Ciência e Ideologia na Prática dos Professores de Sociologia no Ensino Médio: da neutralidade impossível ao engajamento indesejável, ou seria o inverso? Revista Educação \& Realidade, Porto Alegre, v.39, n.1, 2014.

MOREIRA, Daniel Augusto. O método fenomenológico na pesquisa. São Paulo: Pioneira Thomson, 2002.

NASCIMENTO, Anderson Messias Roriso do; GASQUE, Kelley Cristine Gonçalves Dias. Novas tecnologias, a busca e o uso de informação no ensino médio. Inf. \& Soc.:Est., João Pessoa, v.27, n.3, set-dez/2017.

NEGROPONTE, Nicholas. A vida digital. $2^{\mathrm{a}}$ ed. São Paulo: Companhia das Letras, 1995.

OLIVEIRA, Amurabi Pereira. Ensino de Sociologia: Desafios epistemológicos para o Ensino Médio. Revista Espaço Acadêmico, Maringá, 2011, v. 119.

OLIVEIRA, Walas Leonardo de. $O$ docente do ensino médio e as tecnologias da informação e comunicação: análise de possíveis alterações no processo de trabalho. Dissertação. 136 f. Programa de Pós-graduação em Educação, Universidade Federal de Minas Gerais, Belo Horizonte, 2007.

PAPERT, Seymour. A máquina das crianças: repensando a escola na era da informática. Porto Alegre: Artes Médicas, 1994.

PINÇON-CHARLOT, Monique; PINÇON, Michel A teoria de Pierre Bourdieu aplicada às pesquisas sobre a grande burguesia: uma metodologia plural para uma 
abordagem pluridisciplinar. Revista de Ciências Humanas, Florianópolis, $\mathrm{n}$. 25,1999 .

PORCHEDDU, Alba. Zygmunt Bauman: entrevista sobre a educação. Desafios pedagógicos e modernidade líquida. Cadernos de pesquisa, v. 39, n. 137, 2009.

POSSA, André Dala. Interação comunicacional de estudantes do ensino médio: netnografia para compreensão de nova ecologia cognitiva. Tese. 149 f. Programa de Pós-graduação em Ciências da Comunicação, Universidade de São Paulo, São Paulo, 2018.

RAMAL, Andrea Cecilia. Um novo paradigma em educação. Revista Guia da Internet.BR, n. 12, 1997.

RECUERO, Raquel. Redes Sociais na Internet. Porto Alegre: Sulina, 2009.

REIS, Valdeci; MENDONÇA, Geovana; MENDES, Lunardi. De iniciantes a vanguardistas: o uso de tecnologias digitais por jovens professores. HOLOS, ano 34 , vol. 01, 2018.

RICHARDSON, Roberto Jarry. Pesquisa social: métodos e técnicas. 3. edição. São Paulo: Atlas, 2007.

RIESMAN, David. A multidão solitária. São Paulo: Perspectiva, 1971.

RÜDIGER, Francisco. Introdução às teorias da cibercultura: perspectivas do pensamento tecnológico contemporâneo. Porto Alegre: Sulina, 2004.

SANTOS, Boaventura de Sousa. A Gramática do Tempo: para uma nova cultura política. São Paulo: Editora Cortez, 2006.

SANTOS, Valmaria Lemos da Costa; SANTOS, José Erimar dos. As redes sociais digitais e sua influência na sociedade e educação contemporâneas. HOLOS, ano 30, vol. 6, 2014.

SILVA, Walberto Barbosa da. A pedagogia dialógica de Paulo Freire e as contribuições da Programação Neurolinguística: uma reflexão sobre o papel da comunicação na Educação Popular. Dissertação. 85 f. Programa de Pós-Graduação em Educação, Universidade Federal da Paraíba, João Pessoa, 2006.

SILVA, Cristiana Barcelos da; SOUZA, Carlos Henrique Medeiro de; CARMO, Gerson Tavares do. Educação de Jovens e Adultos e novas tecnologias da informação: uma abordagem educacional. HOLOS, ano 32, vol. 2, 2016.

SILVA, Janete Araújo da. As tecnologias da informação e da comunicação e o ensino de sociologia nas escolas públicas do Distrito Federal: Inclusão Digital e capital tecnológico-informacional. Dissertação. 264 f. Programa de Pós-graduação em Sociologia, Universidade de Brasília, Brasília, 2013.

SIMÕES, Isabella de Araújo Garcia. A Sociedade em Rede e a Cibercultura: dialogando com o pensamento de Manuel Castells e de Pierre Lévy na era das 
novas tecnologias de comunicação. Revista eletrônica temática, ano V, n. 05 , 2009.

SIMMEL, Gerog. Sociabilidade, um exemplo de sociologia pura ou formal. In: E. Moraes Filho (org). Georg Simmel: sociologia. São Paulo: Ática, 1983.

SOUZA, Carlos Henrique Medeiros de; COSTA, Marco Aurélio Borges. ABORDAGENS ANTROPOLÓGICAS DO CIBERESPAÇO E DA CIBERCULTURA. Tempo brasileiro, n. 162-163, 2005.

SPEROTTO, Rosária. Educação para a mídia: leitura crítica. In: BOCK, A. M. B. (Org.). Mídia e psicologia: produção de subjetividade e coletividade. $2^{\mathrm{a}}$ ed. Brasília: Conselho Federal de Psicologia, 2009.

THIOLLENT, Michel. Crítica metodológica, investigação social e enquête operária. São Paulo: Polis, 1980.

THIOLLENT, Michel. Metodologia da pesquisa-ação. São Paulo: Cortez; 1986.

THOMPSON, Edward P. Costumes em Comum: estudos sobre a cultura popular tradicional. São Paulo: Companhia das Letras. 1998.

VASCONCELLOS, Maria Drosila. Pierre Bourdieu: a herança sociológica. Educação \& Sociedade, vol. 23, nº 78, abril, Campinas, 2002.

VEIGA-NETO, Alfredo José da. De Internet, cibercultura e inteligências. Episteme: filosofia e história das ciências em revista, Porto Alegre, n. 9, 1999.

VIRILIO, Paul. A bomba informática. São Paulo: Estação Liberdade, 1999.

VIVEIROS DE CASTRO, Eduardo. O nativo relativo. MANA, vol. 8, n 1, 2002.

VYGOTSKY, Lev Semenovitch. A formação social da mente: o desenvolvimento dos processos psicológicos superiores. $4^{a}$ edição. São Paulo: Martins Fontes, 1991. 